No.1735

December 2020

\title{
Are bigger banks better? Firm-level evidence from Germany
}

Kilian Huber 


\begin{abstract}
The effects of large banks on the real economy are theoretically ambiguous and politically controversial. I identify quasi-exogenous increases in bank size in post-war Germany. I show that firms did not grow faster after their relationship banks became bigger. In fact, opaque borrowers grew more slowly. The enlarged banks did not increase profits or efficiency, but worked with riskier borrowers. Bank managers benefited through higher salaries and media attention. The paper presents newly digitized microdata on German firms and their banks. Overall, the findings reveal that bigger banks do not always raise real growth and can actually harm some borrowers.
\end{abstract}

Key words: bank regulation, big banks, bank size, economic growth, Brexit, economic geography, employment, globalisation, productivity, technological change

JEL codes: E24; E44; G21; G28

This paper was produced as part of the Centre's Growth Programme. The Centre for Economic Performance is financed by the Economic and Social Research Council.

\title{
Acknowledgements
}

I am grateful to three referees, Douglas Diamond, Anil Kashyap, Alan Manning, Ricardo Reis, Harald Uhlig, and Alwyn Young for helpful suggestions. I also thank Philippe Aghion, Saleem Bahaj, Bruno Biais, Florian Blum, Francesco Caselli, Nicola Cetorelli, Thomas Drechsel, Erik Hurst, Victoria Ivashina, Randall Kroszner, Ross Levine, Stephan Maurer, Brent Neiman, Daniel Paravisini, Thomas Philippon, Steve Pischke, Raghuram Rajan, Oliver Rehbein, Albrecht Ritschl, Christina Romer, David Romer, Isabel Schnabel, Robert Shimer, Jeremy Stein, Jón Steinsson, Philip Strahan, Amir Sufi, Fabian Waldinger, and Thomas Wollmann for insightful comments. The Economic Archive Hohenheim, the German National Library of Economics, the Historical Archives of Commerzbank, Deutsche Bundesbank, and Deutsche Bank, the University Libraries of Cologne, Tübingen, and Munich, and the Württembergische Landesbibliothek generously supported the data collection. Kenan Jusufovic, Sungil Kim, and Stefan Wies provided excellent research assistance. The research was funded by grants from the Centre for Economic Performance, Centre for Macroeconomics, LSE Institute of Global Affairs, Paul Woolley Centre, Sticerd, and Stiftung Familienunternehmen.

Kilian Huber, University of Chicago and Centre for Economic Performance, London School of Economics.

Published by

Centre for Economic Performance

London School of Economics and Political Science

Houghton Street

London WC2A 2AE

All rights reserved. No part of this publication may be reproduced, stored in a retrieval system or transmitted in any form or by any means without the prior permission in writing of the publisher nor be issued to the public or circulated in any form other than that in which it is published.

Requests for permission to reproduce any article or part of the Working Paper should be sent to the editor at the above address.

(C) K. Huber, submitted 2020. 


\section{Introduction}

The impact of large firms on the economy has recently received significant attention (Zingales 2017; Philippon 2019). The topic is particularly salient in banking. The continued growth of banks in past decades and failures of large banks in recent crises have kept the issue of bank size at the forefront of policy debates. Some policymakers argue that limits on bank size could reduce financial instability and excessive risk-taking. ${ }^{1}$ But if larger banks generate economies of scale, then discouraging banks from growing bigger could decrease the quality of financial services and harm real economic growth.

In this paper, I identify a setting where increases in bank size were exogenous to the performance of banks and their borrowers. This rare occurrence allows me to estimate how changes in bank size causally affected firms in the real economy. The setting is postwar Germany. Reforms in 1952 and 1957 determined when several institutions were allowed to consolidate from state-level banks into national banks. I find that, on average, firms did not grow faster after their banks became larger. The consolidations did not make the banks more cost efficient or profitable. These findings show that increased bank size does not always generate improvements in bank efficiency or firm growth, in contrast to leading theories. Furthermore, opaque (small, young, low-collateral) firms grew more slowly after their banks got bigger, consistent with the view that bigger banks are worse at processing soft information.

The effect of bank size on borrower growth depends on the strength of several mechanisms that have been analyzed theoretically. On the one hand, theory suggests that bigger banks might be more efficient and stable. For instance, bigger banks spread fixed costs over more borrowers (Humphrey 1990), are more diversified (Diamond 1984), issue large loans without syndication (Holmstrom and Tirole 1997), and generate operational synergies (Kanatas and Qi 2003). Bigger banks might also improve screening and the allocation of capital across borrowers (Stein 1997, 2003). These channels could raise the average growth of bank borrowers. On the other hand, diversification might not be beneficial once banks exceed a certain size (Krasa and Villamil 1992b; Cerasi and Daltung 2000). Large organizations might entail complex agency and information problems (Rajan et al. 2000; Scharfstein and Stein 2000; Berger and Udell 2002; Stein 2002). These channels could harm borrower growth. $^{2}$

Given the ambiguous theoretical predictions, the effect of bank size on firm growth is an empirical question. I first estimate the overall effect of the banking consolidations on borrower growth. The results capture how the various theoretical mechanisms, on net, impacted firm growth. Thereafter, I turn to assessing individual theories about bank operations. I provide evidence on which theoretical

\footnotetext{
${ }^{1}$ The market share of the ten biggest US banks increased from around 25 percent in 1990 to over 60 percent in 2014 (McCord and Prescott 2014). Recent regulatory proposals include outright caps on bank size as well as indirect incentives for banks to remain small, for example higher capital requirements and stress tests for big banks (Stern and Feldman 2004; Stein 2013; Greenwood et al. 2017).

${ }^{2}$ The banking reforms in postwar Germany increased bank size without directly deregulating local competition or entry, so I do not analyze the effects of bank size on local competition in this paper.
} 
mechanisms were important determinants of bank efficiency and firm performance after banks got bigger.

The empirical challenge in estimating the effects of bigger banks is that banks do not become big randomly. For example, a bank might strategically consolidate with another bank if it expects the borrowers of the other bank to grow faster in future. In such cases, one would observe a positive correlation between bank size and the growth of borrowers even if bank size has no causal effect on borrowers. Two features of the postwar German banking system allow me to overcome this challenge. The first feature is the reliance of German firms on relationship banking. Due to asymmetric information, bank-borrower relationships were sticky. This means that shocks to a given bank affected the cost of banking services for its relationship borrowers.

The second feature is the banking policy of the Allied occupiers in postwar Germany. The Allies believed that three banks with nationwide branch networks (Commerzbank, Deutsche Bank, and Dresdner Bank) had contributed to the Nazi war effort. These banks constitute the treatment group for the purposes of this paper. In 1947/48, the Allies broke up the treated banks into 30 independent state-level organizations and prohibited the new banks from branching outside state borders. A first reform in 1952 permitted some of the state-level banks to consolidate with other state-level banks within three banking zones. This meant that the 30 state-level banks merged to become nine treated institutions, one for each former national bank in each banking zone. A second reform in 1957 permitted the reconsolidation of the three original, national banks. Hence, borrowers with a treated relationship bank experienced sharp increases in the size of their relationship banks in 1952 and $1957 .^{3}$

The history of banking is replete with cases of banks that have sought to consolidate. The prevailing sentiment among the managers of treated banks in postwar Germany was no different. They had wanted to reconsolidate from the moment of their initial breakup. The key advantage of this setting is that when the banks were allowed to consolidate was determined by the reforms. Improvements in the attitude of the Allies toward Germany, mainly due to the emergence of the Cold War, made the reforms possible. Negotiations among German politicians, central bankers, bank representatives, and the Allies then determined specifically when the consolidations happened.

Historical records suggest that the consolidations affected how the banks operated. They increased diversification, organizational complexity, and hierarchical decision-making; enabled the banks to use internal capital markets and to spread out fixed costs; and reduced the need for loan syndicates. Importantly, the reforms did not directly affect determinants of bank efficiency unrelated to size, such as the kinds of services offered by the banks or the number of branches operating in each local market. This allows me to examine how increases in bank size affected banks and borrowers while keeping constant spurious confounders that are usually correlated with changes in bank size.

\footnotetext{
${ }^{3}$ I focus on the 1952 and 1957 reforms. I do not analyze the impact of the 1947/48 breakup because no data exist for the immediate postwar period.
} 
Policymakers often consider a bank systemically important if its assets exceed roughly 1-2 percent of GDP. During the breakup, all of the treated state-level banks were below this threshold, relative to German GDP at the time. After they had reconsolidated in 1957, the assets of each treated bank exceeded 1 percent of GDP. Hence, the repeal of the Allied legislation transformed the treated banks from 30 state-level lenders into three banks of systemic importance.

One contribution of this paper is to present the first digital micro-dataset on firms in postwar Germany. The data were hand-digitized from historical firm records and cover the postwar period until 1970. The new dataset allows researchers to study the corporate side of Germany's “economic miracle" after World War II. It includes the bank relationships of around 5,900 firms, employment growth of around 2,300 firms, and balance sheet variables of around 400 firms.

In the main analysis of the paper, I examine how the consolidations among the treated banks, induced by the banking reforms, affected the growth of firms. I compare firms with a treated relationship bank to firms with untreated banks. I find that firms with a treated relationship bank grew in parallel to firms with untreated banks before 1952, suggesting that they would have continued to grow in parallel in the absence of the banking reforms. In the cleanest empirical test, I analyze the growth of firms around 1952. Because the 1952 reform did not affect any banks located in the state of North-Rhine Westphalia, I can compare firms located in North-Rhine Westphalia, whose banks were only treated in 1957, to firms in bordering states, whose banks were treated in both 1952 and 1957. This test overcomes the concern that firms with a relationship bank treated by the postwar banking reforms were on different growth paths than other firms.

The main results show that firms did not experience faster growth rates of bank debt, employment, or revenue per worker if they had a relationship bank that was treated by a reform. The estimates are similar for firms that were more dependent on banking services. Firms that were newly added as relationship borrowers by the treated banks after the consolidations also did not grow faster than comparable firms. The treated banks themselves did not lend more or add more relationship borrowers after consolidating, relative to other banks.

I separately examine a subsample of firms that were small, young, or in industries with a low share of easily collateralizable assets. These firms were "opaque" because when they applied for loans they relied on their banks to process hard-to-verify, soft information. For example, opaque firms were more likely to receive unsecured "character loans." Opaque firms substituted bank debt with other sources of financing after their relationship banks grew in size, indicating an increase in their relative cost of bank debt. Opaque firms with no access to stock market funding reduced employment growth. There were no corresponding effects on large or non-opaque firms with a treated relationship bank. These results are consistent with theories arguing that big banks are worse at processing soft information.

In the final set of main results, I examine the effects of the consolidations at a higher level of aggregation, on municipalities. The municipality-level results capture not only the effects on firm growth, but also other potential channels, such as local general equilibrium effects or changes in the 
municipal banking market. I find that municipalities with a treated bank branch experienced lower employment growth after the reforms. The negative effect on municipalities is consistent with the firm-level results because opaque firms grew more slowly and other firms did not benefit from the consolidations.

A range of theories predicts how changes in bank size affect bank and borrower outcomes. I discuss the theoretical mechanisms that may have played a role. Some theories suggest that bank profitability and efficiency always rise with size. However, I find that the treated banks did not become more profitable or efficient after consolidating, relative to comparable untreated banks. Diversification theory predicts that bigger banks are more stable and experience larger deposit inflows. I find that fluctuations and deposit inflows of the treated banking groups did not improve after the consolidations. This suggests that the benefits of diversification only apply to relatively small banks.

There is also no evidence that the enlarged banks' ability to issue large loans or to cross-sell products impacted borrowers. Allowing banks to use internal capital markets did not significantly alter the allocation of capital, likely because interbank markets were adequate substitutes for internal capital markets (Horstmann 1991). Finally, I show that the treated banks were more likely to establish new relationships with risky firms (firms with high volatility or high leverage) after consolidating, relative to other banks. This suggests that the treated banks were willing to take greater risks, consistent with theories that emphasize "too big to fail" incentives.

If the consolidations did not improve profits or efficiency, why did the treated bank managers favor consolidating? I report that the pay of treated bank managers rose after the consolidations, relative to untreated managers. While the literature has documented that firm size and executive pay are correlated (Edmans et al. 2017), this finding suggests that increases in size cause greater pay. Furthermore, I find that the media mentions of the treated managers increased. Managers might enjoy media coverage as an end in itself. Media coverage might also have tangible benefits to firms because it can affect consumer choices and political decisions (Enikolopov and Petrova 2015; Bursztyn and Cantoni 2016). Overall, greater salaries and media mentions might explain why managers enjoy building corporate "empires" (Stein 2003).

The results from different datasets and analyses all paint a consistent picture: bigger banks did not improve the growth of borrowers. Whether bigger banks benefit or harm borrowers depends on the net impact of efficiency-enhancing and harmful mechanisms. Leading theories imply that certain mechanisms, such as improved cost structures or diversification, should boost bank and borrower outcomes after banks get bigger. The experience from postwar Germany highlights that the efficiency-enhancing mechanisms do not always outweigh the harmful effects. 


\section{Related Empirical Literature}

Existing evidence about the impact of bank size on bank efficiency is mixed (Berger and Mester 1997; Rhoades 1998; Berger et al. 1999). ${ }^{4}$ Most existing work is based on cross-sectional comparisons or bank consolidations. It is generally difficult to estimate causal effects using cross-sectional data or consolidations. Cross-sectional differences in bank size might be driven by reverse causality, that is, banks might have first improved their efficiency and then become bigger as a result. Bank size might also be correlated with unobservable variables, such as the quality of managers (Kovner et al. 2014). Moreover, consolidating banks are often systematically different from other banks and control groups are hard to find (Calomiris 1999; Calomiris and Karceski 2000; Focarelli et al. 2002).

This paper contributes to the literature by identifying bank consolidations whose timing was exogenous to the growth of banks and their borrowers. This allows me to estimate how a shock to bank size causally affected firms, municipalities, and banks. I analyze not only the effects on financial outcomes of banks, but also how the real growth of firms and municipalities changed.

A literature has analyzed how big banks interact with small borrowers. Cross-sectional evidence suggests that big banks lend proportionally less to small firms (Berger et al. 1995, 2005). The evidence from bank consolidations is mixed (Berger et al. 1998, 2001; Peek and Rosengren 1998; Strahan and Weston 1998; Sapienza 2002; Jagtiani et al. 2016). I contribute to this literature in three ways: by showing that increases in bank size can have negative effects on employment; by highlighting negative effects not just for small firms, but also for young and low-collateral firms; and through cleaner identification, by exploiting quasi-exogenous variation in the size of the same bank serving the same firm. ${ }^{5}$

An influential literature shows that banking deregulation affected the US economy, starting with seminal papers by Hubbard and Palia (1995) and Jayaratne and Strahan (1996), and recently reviewed by Berger et al. (2019). Several papers emphasize that increases in the number of banks in local markets and the threat of new bank entry were chiefly responsible for the effects of deregulation. ${ }^{6}$ In contrast, the banking reforms in postwar Germany increased bank size without directly deregulating local competition or entry. ${ }^{7}$ A further difference is that I analyze state-level banks that

\footnotetext{
${ }^{4}$ Some recent papers using cross-sectional data suggest that returns to scale might have increased over time (Feng and Serletis 2010; Wheelock and Wilson 2012, 2018; Hughes and Mester 2013; Davies and Tracey 2014; Kovner et al. 2014; Biswas et al. 2017; Hughes et al. 2019).

${ }^{5} \mathrm{~A}$ related literature shows that banks with longer hierarchies are less reliant on soft information (Cole et al. 2004; Liberti and Mian 2009; Cerqueiro et al. 2011; Canales and Nanda 2012) and use internal information differently (Qian et al. 2015). Adding hierarchical layers in Indian bank branches, keeping overall bank size constant, reduced lending and loan performance (Skrastins and Vig 2018).

${ }^{6}$ Both intrastate branching and interstate banking allowed "banks to enter new markets and threaten incumbent banks" (Stiroh and Strahan 2003; see also Jayaratne and Strahan 1998 and Evanoff and Ors 2008). Intrastate branching increased the actual number of competitors in local markets and the threat of new banks entering, which raised competitive pressures on incumbents even if there was no actual entry (Jayaratne and Strahan 1996). Interstate banking raised competitive pressures by affecting the number of participants in the market for corporate control (Hubbard and Palia 1995).

${ }^{7}$ Banking was a local business in postwar Germany (Eicke 1952), so state-level treated banks that had belonged to the same national banking group did not compete with each other across states (Horstmann 1991). Consistent with these
} 
consolidated into national banks, while many US banks operated at the city level before deregulation. The results in this paper therefore speak to consolidations among relatively larger banks.

In related historical work, Eichengreen and Ritschl (2009) analyze the German postwar economy and Hoshi and Kashyap (2004) describe how the US occupiers reformed Japanese corporate finance. 8

\section{Relationship Banking and Reforms in Postwar Germany}

This paper's methodology relies on two institutional features of the German postwar banking system: relationship banking and the banking reforms. This section describes the two features. In combination, they give rise to quasi-experiments, in which firms with a treated relationship bank were exposed to exogenous increases in the size of their banks.

\section{III.A Relationship Banking}

Three types of banks operated in postwar Germany: commercial, cooperative, and public banks. Commercial banks, including the treated banks, operated for profit and offered the full range of banking services, including lending, deposit taking, payment transactions, and underwriting of securities.

Relationship banking is an integral part of the German banking system. Firms of all sizes have formed close and durable ties to their relationship banks since the late 19th century (Calomiris 1995; Elsas and Krahnen 1998; Fohlin 1998; Harhoff and Körting 1998; Guinnane 2002). In postwar Germany, relationship banks had specialized knowledge that allowed them to assess the creditworthiness of their relationship borrowers (Menzel 1960; Pohl 1973). They managed all banking business for their borrowers, including satisfying credit demand (Eicke 1952). ${ }^{9}$

Longstanding ties between banks and firms improve banks' screening and monitoring capabilities (Sharpe 1990; Boot 2000). At the same, firm-bank relationships become sticky, so that idiosyncratic shocks to relationship banks affect the growth of borrowers. ${ }^{10}$ Firms' demand for banking services was particularly high in the fast-growing economy of postwar Germany, so banking shocks had the potential to affect real outcomes (Holtfrerich 1995, page 544).

facts, the data on bank-firm relationships in 1951 show that 99 percent of firms had treated relationship banks only in the state of their headquarters. The exceptions may be explained by firms operating multiple establishments.

${ }^{8}$ By analyzing a unique historical event to test whether influential theoretical predictions always hold in the data, this paper is inspired by a long tradition at the intersection of macroeconomics and finance. Influential examples include Gorton (1988) and Richardson and Troost (2009) on banking panics, Calomiris (1990) on deposit insurance, Jayaratne and Strahan (1996) on banking deregulation, and Calomiris and Mason (2003) on consequences of bank failures.

${ }^{9}$ Banking relationships rarely ended in postwar Germany: 96 percent of firms that had a treated relationship bank in 1951 still had one in 1960.

${ }^{10} \mathrm{~A}$ large literature has shown this in many periods and countries, including Doerr et al. (2020) for the 1931 German banking crisis, Benmelech et al. (2019) for the US Great Depression, Amiti and Weinstein (2011) for Japan from 1990 to 2010, and Bentolila et al. (2018) and Huber (2018) for the 2008-09 crisis in Spain and Germany, respectively. 


\section{III.B Banking Reforms}

Three Allied military governments ruled over West Germany after World War II. The British were in charge of northern and western Germany, most of the south was under American control, and the French governed two small regions in the south-west. The military government of the American zone was the driving force behind banking policy (Horstmann 1991).

Phase 1: State-level Breakup 1947/48-52 During the initial years of the occupation, the American objective was to reorganize the German economy, so that it would not be able to support a future war. The Dodge Plan of 1945 argued that the centralized banking system had enabled the Nazis to fund the war. As a result, the Americans set out to break the economic and political influence of large centralized banks (Adler 1949). They focused their regulatory efforts on the three banks with nationwide branch networks that were still active after the war: Commerzbank, Deutsche Bank, and Dresdner Bank. I refer to these three banking groups as "treated."

In March 1946, the American and French military governments prohibited branches in their zones from coordinating business with managers in other zones. This effectively ended the national operations of the treated banks (Wolf 1993, page 28). In May 1947, the Americans formally created new state-level banks in their zone. Each state-level bank was not allowed to operate a branch in another federal state. The names of the new institutions were unrecognizable from the former national names, to underscore that the newly formed entities were separate from each other. The directors of the state-level banks were the regional and national managers of the former national banks. Government-appointed custodians, independent and unconnected to the former banks, were in charge of ensuring that the state-level banks operated independently and formally administered the banks' property (Adler 1949; Horstmann 1991, page 169). The relationship between individual branches and their customers, the local market share of branches, and the financial services they offered remained unchanged (Adler 1949). What changed was that each branch now belonged to a much smaller state-level bank, rather than to a national organization.

The French military government issued an identical decree for its zone in September 1947. The British were initially against the breakup, but gave in to US pressure and applied a similar regulation in their zone in April 1948. Allied legislation meant that there were now 30 separate state-level banks, whose branches had belonged to three national banks before the war (panel A, Figure I). ${ }^{11}$ The Allied laws did not directly affect the other commercial, cooperative, or public banks.

The treated state-level banks acted "with autonomous management, independent custodians, and distinct business policies" and "appeared unrelated to the former national banks" (Horstmann 1991,

\footnotetext{
${ }^{11}$ To be clear, consider the example of Dresdner Bank: Instead of one national Dresdner Bank, as before the war, there were 11 state-level successor banks in 1948, one in each state. Each state-level bank was composed of the former Dresdner Bank branches in the relevant state. Deutsche Bank had not previously operated branches in SchleswigHolstein, so there were 10 Deutsche Bank successors. Commerzbank had not previously operated branches in Baden and Württemberg-Hohenzollern, so there were 9 Commerzbank successors.
} 
page 151). Deutsche Bank, for instance, "was decentralized after April 1, 1948, for all practical purposes" (Holtfrerich 1995, page 484). The Allies intended the breakup to the state level to be permanent (Der Spiegel 1951). Several other firms that were broken up after the war were not allowed to reconsolidate in future years. ${ }^{12}$ Any hopes for national reconsolidation that may have existed among the bank managers in 1949 were "wishful thinking" (Horstmann 1991, page 181).

Phase 2: Three Banking Zones 1952-57 By the early 1950s, the American diplomatic stance toward West Germany had mellowed (Scholtyseck 2006). Hoping that a stable German economy could stop the spread of Communism, the Americans became open to German suggestions about how to facilitate growth. The German federal government and managers of treated banks had always maintained that operating as separate banks harmed the banks and their borrowers (Ahrens 2007). The Americans made it clear that they were willing to consider some form of partial reconsolidation among the treated banks, but would veto full reconsolidation at the national level (Holtfrerich 1995).

The sides reached a compromise that was passed as law in March 1952. The law defined three banking zones (panel B, Figure I). The state-level banks were allowed to consolidate with other state-level banks belonging to the same former national bank and located within the same banking zone. Other consolidations and out-of-zone branching was prohibited. Because the borders of the the state of North-Rhine Westphalia were identical to the borders of the new western zone, banks operating in the western zone remained unaffected by the 1952 reform.

The treated banks were not forced to reconsolidate. But the vast majority of treated bank directors believed that they would benefit from reconsolidation. Hence, all the state-level banks in the northern and southern zones decided to consolidate in September 1952. Instead of 30 state-level banks, there were now nine treated banks, one for each former national bank in each banking zone (Wolf 1993). The directors of the former state-level banks became the board members of the nine new banks.

The 1952 reform affected the operations of the treated banks. They were able to spread fixed costs over a larger base, to fund large loans on their own instead of through syndicates, to use internal capital markets to transfer capital across states, and to work with a more diversified lending portfolio and depositor base (Lanner 1951; Wandel 1980; Holtfrerich 1995). Historians disagree to what extent these operational changes affected the performance of banks and their borrowers (Pohl 1986; Horstmann 1991). The rules of the breakup that had applied to the state-level banks remained in place for the zonal banks, but the Allies did not enforce the rules as strictly as before $1952 .{ }^{13}$ As a result, my analysis below emphasizes the effects of the 1952 reform and compares bank and firm outcomes before and after 1952 .

\footnotetext{
${ }^{12}$ To reduce the likelihood of a future war, the Allies also broke up the chemical manufacturer I.G. Farben, the steel corporation Vereinigte Stahlwerke, and the movie producer Universum Film. Unlike in the case of banking, German politicians did not believe these other industries would generate significant economies of scale. Hence, these organizations were not allowed to reconsolidate to their former structures in sovereign Germany, despite the wishes of their management (Kreikamp 1977).

${ }^{13}$ For example, the directors of the successor institutes of Dresdner Bank met around six times a year, starting in late 1952, as did the directors of the Deutsche Bank successor banks (Ahrens 2007; Holtfrerich 1995).
} 
Phase 3: National Banks from 1957 During the 1950s, the Cold War made Germany a key ally of the West. The Allies granted the German government full sovereignty in the Paris Agreement of 1955. One condition for sovereignty set by the Allies was that the treated banks would remain separated at least until 1956. The German federal government passed a law that allowed national reconsolidation of the treated banks from January 1957 (Scholtyseck 2006). The banks consolidated soon thereafter. By 1958, there were once again three large banks with a national branch network, operating under their old, prewar names.

\section{Empirical Strategy}

The treated banks favored consolidation throughout the postwar period. This makes them comparable to many other banks in the past and present that want to merge. The key difference is: Government reforms, not endogenous shocks to banks and their borrowers, determined how and when the treated banks consolidated. This means that the reforms generate quasi-experiments that allow estimating how changes in bank size causally affect banks and their borrowers. A formal model in Appendix B illustrates how the reforms help to overcome the usual empirical challenges in estimating the effects of bank size on firm growth.

The main empirical analysis of the paper studies whether firms with a treated relationship bank grew differently to firms with other relationship banks after the reforms. Specifically, I regress measures of firm growth on an indicator for whether one of the firm's relationship banks was treated by a reform. The coefficient on the indicator captures all the channels through which a change in bank size could affect firms. Potential channels include cheaper access to loans and deposits, improved underwriting and payment services, and less uncertainty about future credit access. I investigate the effects on both firms that already had a treated relationship in 1951 and on firms that newly added a treated relationship bank after a reform.

The empirical strategy estimates the causal effect of having a treated relationship bank if a parallel-trends assumption holds. This assumption requires that, had it not been for the reforms, firms with a treated relationship bank would have grown in parallel to other firms. The results sections below present evidence in support of the identification assumption, for instance by showing that there were parallel pre-trends and that the results are robust to controlling for other shocks.

The main regressions use all firms with available data in the sample. To create a tighter empirical test of the effects of the 1952 reform, I additionally create a more restrictive, "focused" sample. The focused sample includes only firms whose relationship bank was broken up by the Allies after the war. This restriction addresses the concern that firms with a treated relationship bank were on different growth paths to firms with banks that were never treated. Furthermore, the focused sample contains only firms located in the western zone (i.e., the state of North-Rhine Westphalia) or in states bordering the western zone. The western zone was a hasty postwar creation, based on the British desire to institutionalize its control over western Germany. Many subregions of the western zone 
were culturally more similar to the states they bordered than to the other subregions in the western zone (von Alemann 2000). Finally, I drop firms located in the Ruhr area, an urban region in the western zone based on heavy industry, as well as coal and steel producers from the focused sample. These restrictions ensure that the formation of the European Coal and Steel Community in 1952 does not bias the results.

Regressions using the focused sample identify the effect by comparing relationship borrowers of banks treated in both 1952 and 1957 (located in states bordering the western zone) to borrowers of banks treated only in 1957 (located in the western zone). The use of the focused sample strengthens the parallel-trends assumption because the restrictions make it likely that all firms in the focused sample were affected by similar unobservable shocks.

\section{Firm Data and Summary Statistics}

At the heart of the paper lies a newly digitized dataset on German firms in the 1950s. The data are from two publication series by the publisher Hoppenstedt. Supported by the German National Library of Economics, I was able to access the 1941, 1952, 1958/59, and 1970 volumes of Handbuch der Grossunternehmen and the 1952/53, 1961/62, and 1970/71 volumes of Handbuch der deutschen Aktiengesellschaften in various German archives. ${ }^{14}$ The poor print quality of the historical volumes makes automatic character recognition difficult, so the data had to be digitized by hand. I describe the data construction and summary statistics in more detail in Appendix C.

The series on Aktiengesellschaften provides information on the universe of German stock corporations. ${ }^{15}$ The available data allow me to calculate the growth of stock corporations' employment, revenue per worker, total assets, liabilities, and bank debt from 1951 to 1960. The series on Grossunternehmen reports a subset of firms of other legal forms, for which I can calculate employment growth from 1951 to 1956 . I also carry out supplementary analyses using longer periods of firm growth based on the 1941 and 1970 Grossunternehmen and the 1970/71 Aktiengesellschaften volumes. To measure firm growth, I use the symmetric growth rate. ${ }^{16}$ To accommodate comparisons across periods of different lengths, I calculate all firm growth rates as average annual growth rates, by dividing the symmetric growth over the entire period by the number of years in the period. ${ }^{17}$

The sample firms are fairly representative for aggregate growth during this period. Aggregate employment growth in West Germany was 4.2 log points per year (on average) from 1951 to 1956

\footnotetext{
${ }^{14}$ The historical volumes of these series are difficult to locate. Hoppenstedt destroyed its entire archive a few years ago. Library catalogs do not always report holdings accurately because historical volumes are often misplaced or destroyed.

${ }^{15}$ To be registered as stock corporation, firms had to hold at least 100,000 Deutsche Mark in stock capital. The advantage of registering as stock corporation was that firms could raise funds by issuing new stock capital.

${ }^{16}$ Formally, the symmetric growth of $y$ from $\mathrm{t}-1$ to $\mathrm{t}$ is $g^{y}=2 \cdot \frac{\left(y_{t}-y_{t-1}\right)}{\left(y_{t}+y_{t-1}\right)}$. It is a second-order approximation to the growth rate of the natural logarithm and is bounded in the interval $[-2,2]$ (Davis et al. 1998). It naturally limits the influence of outliers and accommodates zeros in the outcome variable, for example due to firm exits.

${ }^{17}$ For example, the total symmetric growth rate from 1951 to 1960 is divided by 9 , the number of years between the base and final year. This gives the average annual growth rate.
} 
and $3.5 \log$ points from 1951 to 1960 . Employment of the average sample firm grew by $4.3 \log$ points annually from 1951 to 1956 and $3.2 \log$ points from 1951 to 1960 . Sample firms with nonmissing employment data cover 15 percent of West Germany's 14.6 million employees in 1951 (Bundesministerium für Arbeit 1951).

Both publication series provide the names of firms' relationship banks. I calculate two main treatment indicators. The first, called "relationship bank treated in 1952/57," indicates whether one of the firm's relationship banks in 1951 was treated by at least one of the banking reforms in 1952 or 1957. The second treatment indicator, called "relationship bank treated in 1952," measures whether one of the firm's relationship banks was treated by the 1952 reform, that is, whether a relationship bank belonged to a treated banking group and was located outside of the western zone. There is no information on which financial services or how much lending a firm received from a particular relationship bank. 43 percent of firms had a relationship bank treated in 1952, while 69 percent of firms had a relationship bank treated in either 1952 or 1957 (Table A.I).

To test whether firms with a treated relationship bank were different, I regress each treatment indicator on firm characteristics. In the full sample, firms with a relationship bank that was treated in 1952 or 1957 were larger and older (Table A.II, column 1), but the firms did not finance themselves with more stock capital or bank debt, conditional on size and age (column 2). Correlations between firm characteristics and treatment indicators do not invalidate the empirical strategy, because it assumes only parallel trends and because I can control for observable differences. In the focused sample, there is no significant association between having a bank treated in 1952 and size, age, stock capital, or bank debt financing (columns 3 and 4). This confirms that, in the focused sample, observationally equivalent firms were exposed to different bank size shocks.

\section{Main Results on the Growth of Banks, Firms, and Municipalities}

This section presents the main results of the paper. I analyze how the banking reforms of 1952 and 1957 affected the growth of treated banks, of firms with a treated relationship bank, and of municipalities with treated branches.

\section{VI.A The Growth of Treated Banks}

I first examine the growth of bank lending and deposits. The Deutsche Bundesbank provides data aggregated at the level of different groups of banks. One group includes all treated banks. The most comparable untreated group in terms of structure and business strategy includes other commercial banks. ${ }^{18}$ Before 1952, total lending to firms and households of treated and untreated commercial banks evolved in parallel (panel A, Figure II). This suggests that the treated banks were on parallel

\footnotetext{
${ }^{18}$ There were 131 commercial banks in 1951 (excluding single-branch private banks, Deutsche Bundesbank 1976). Most were active within only one state, although a few had branches in several states. Their market share in lending to German non-banks was 14 percent in 1951, while the treated banks' market share was 21 percent.
} 
growth paths to untreated banks and that the postwar breakup did not have persistent effects. After the 1952 reform, the loan growth of the treated banks slowed relative to the untreated group, and continued to do so after the 1957 reform. The growth pattern of deposits mirrored that of lending (panel B, Figure II). ${ }^{19}$ The results suggest that the treated banks did not expand their loan supply and deposit base after consolidating, relative to other banks. Moreover, one key aim of the treated banks in the postwar period was to gain market share. ${ }^{20}$ The results in Figure II imply that the consolidations did not facilitate this aim.

\section{VI.B The Growth of Non-Stock Firms with a Treated Relationship Bank}

I turn to investigating how firms borrowing from the treated banks were affected by the consolidations. Since the data for non-stock firms and stock corporations are from separate sources and for different years, I analyze the firm types separately. To begin, I examine the employment growth of non-stock firms from 1951 to 1956. I regress average annual employment growth from 1951 to 1956 on an indicator for whether a bank treated in 1952 was among the firm's relationship banks in 1951. ${ }^{21}$ If the 1952 reform allowed bank borrowers to grow faster, the coefficient on the indicator should be positive. However, the estimate is statistically not different from zero (column 1, Table I). It implies that the growth of firms with a treated relationship bank was 0.1 percentage points lower per year. The 95 percent confidence interval ranges from -0.8 to 0.6 percentage points. ${ }^{22}$

The coefficient hardly changes when I add control variables (column 2). Since shocks to certain industries might have differed across regions, I include fixed effects for industries interacted with fixed effects for the northern, western, and southern regions of Germany. ${ }^{23}$ I also control for $\ln$ firm age and for four bins of firm employment in 1951 (0-49, 50-249, 250-999, and 1000+ employees), all interacted with the three zonal fixed effects.

\footnotetext{
${ }^{19}$ The pattern remains similar until 1970, suggesting that the relative decline of the treated banks cannot be explained by temporary adjustment costs (Figure A.I). The pattern is also similar using all other German banks in the untreated group, including the cooperative and public banks (Figure A.II).

${ }^{20}$ The banks openly expressed their desire to expand market share both before and after 1952 (Ahrens 2007, page 227; Dresdner Bank report 1958). For example, the directorate of the Rhein-Main-Bank (located in Hesse) encouraged its staff to "poach customers" from other banks, by carefully "working through incoming mail to scout for new business opportunities (for example, by reading between the lines)" (circular to all branches from August 1948, Ahrens 2007, page 227). The Nazis had instituted a ceiling on deposit rates in 1936, which was officially still in place after the war. There was only a non-binding "recommendation" for the lending rate (Herlan 1952, page 656). In practice, banks in postwar Germany largely ignored rate regulation and recommendations. They paid competitive deposit rates and outbid each other on fees and other costs of financial services (Die Zeit 1954; Wolf 1998, page 70).

${ }^{21}$ To be clear, the outcome in Table I is the symmetric growth rate of bank debt from 1951 to 1956 divided by 5 (the number of years between 1951 and 1956). This transformation makes it easier to compare the point estimates to later results, which use data for periods of different lengths.

${ }^{22}$ Standard errors in the baseline are clustered at the level of the firm's county, but are similar when clustering by state-level banks and using the cluster correction by Young (2016) (columns 4 and 5, Table A.IV).

${ }^{23}$ The industries are: agriculture \& mining, food \& drink, clothes \& textiles, wooden products, chemicals \& pharmaceuticals, rubber $\&$ glass, metals manufacturing, electric \& electronics, production of machinery, repair $\&$ research, energy supply, water \& waste management, construction \& real estate, trade \& retail, transport, gastronomy \& art, information \& communication, and finance \& insurance. The regions are equivalent to the three banking zones of the 1952-57 period.
} 
A remaining concern is that firms with a treated relationship bank would have been on different growth paths during the 1950s, had it not been for the reforms, for example because they were persistently affected by the banking breakup after World War II. To address this concern, I show that firms with a treated relationship bank grew in parallel to other firms from 1949 to 1951 (Table A.III). Moreover, I restrict the analysis to the "focused" sample. The main feature of the focused sample is that it only contains firms that had a treated relationship bank that was broken up after the war. Some firms in the focused sample were treated in 1952 and some were not, due to the exclusion of the western zone from the 1952 reform. ${ }^{24}$ The coefficients in the focused sample remain close to the baseline (columns 3 and 4, Table I). Hence, differences between firms with a treated relationship bank and other firms do not explain the results.

Exporters are more likely to be affected by banking shocks because they have higher default risk and working capital requirements (Amiti and Weinstein 2011). The stable coefficient for exporters suggests that even firms with higher bank dependence did not benefit from the consolidations (columns 5 and 6). The 1952 reform had the largest effects on bank operations in a few southern states that had enforced the rules of the breakup relatively strictly: Baden, Bavaria, Hesse, Rhineland-Palatine, Württemberg-Baden, and Württemberg-Hohenzollern. The southern state governments were in favor of state-level banks (Horstmann 1991, pages 231, 250) and considered the 1952 reform to be problematic (Wolf 1993). But even in the strict states, the effect was small and insignificant (columns 7 and 8). In additional tests, I show that the results are robust to different treatment measures and sample cuts (Appendix D).

\section{VI.C The Growth of Stock Corporations with a Treated Relationship Bank}

For stock corporations, I analyze the growth of employment, bank debt, bank debt over total assets, and revenue per worker from 1951 to 1960 . The regressor of interest is an indicator for whether a bank treated in 1952 or 1957 was among the firm's relationship banks in 1951. The effects on stock corporations' employment are small and insignificant, without and with control variables (columns 1 and 2, panel A, Table II). ${ }^{25}$ The literature has shown that firms with high bank debt and high leverage react more strongly to shocks to their relationship banks (Bentolila et al. 2018; Huber 2018). I find no evidence that firms with high bank debt or low stock capital (relative to assets) in 1951 grew faster if they had a treated relationship bank (columns 3 and 4). This confirms that even bank-dependent firms did not benefit from the bank consolidations.

Moreover, there is no evidence of an effect on bank debt (panel B, Table II), the ratio of bank debt over assets (panel C), or revenue per worker (panel D) from 1951 to 1960. The small effect on bank debt confirms that the treated banks did not expand loan supply to their relationship borrowers.

\footnotetext{
${ }^{24}$ For the full set of restrictions in the focused sample, see Section IV. The focused sample identifies the effect by comparing across zones, so I do not control for zonal fixed effects in columns 3 and 4 of Table I.

${ }^{25}$ Since employment is not available for all stock corporations, I use ln assets to control for firm size in Table II. Results are similar when controlling for employment as in Table I.
} 
By using the ratio of bank debt over assets as outcome, I implicitly control for changes in firms' total demand for funding in a way that is conceptually similar to using firm fixed effects. If firms with a treated relationship bank had access to cheaper bank debt, they should have funded themselves with more bank debt relative to other funding sources, raising the ratio. Finally, revenue per worker is a measure of labor productivity. The small effect suggests that firms did not make their workers more productive after their banks consolidated.

\section{VI.D The Growth of Opaque Firms with a Treated Relationship Bank}

Big banks might be worse at dealing with opaque firms because it requires collecting and processing soft information. To identify opaque firms, I follow previous work and restrict the sample to firms that in 1951 had fewer than 50 employees, were younger than ten years old, or were unlikely to have easily collateralizable assets (firms where the share of fixed tangible assets in their industry was in the bottom ten percent). ${ }^{26}$

Opaque stock corporations with a treated relationship bank reduced the ratio of bank debt over assets by 1.4 percentage points from 1951 to 1960, relative to other opaque stock corporations (significant at 5 percent, column 1, Table III). Their stock capital over assets increased by 0.6 percentage points, although the effect is imprecisely estimated (column 2). These findings suggest that opaque stock corporations suffered lower bank loan supply but were able to raise stock capital financing in response. There was no effect on stock corporations' employment (column 3). If treated banks caused the decline in bank loan supply, firms with few alternative banks should have suffered the largest decrease in bank debt. In line with this view, I find a significant effect on the ratio of bank debt over assets only if more than half of a firm's relationship banks were treated (column 4).

The employment of non-stock firms is more vulnerable to banking shocks because they cannot finance themselves by issuing stock capital. I find that the employment growth of opaque non-stock firms was 2.9 percentage points lower when more than half of relationship banks were treated (significant at 10 percent, column 5), relative to opaque non-stock firms without treated relationship bank. The effect remains of similar magnitude and significant when I use the focused sample (column 6). In summary, the results suggest that the treated banks were worse at dealing with opaque borrowers after the consolidations. ${ }^{27}$

\footnotetext{
${ }^{26}$ Firms with fewer than 50 employees face more idiosyncratic risk, have lower savings, and are hard for lenders to assess (Gertler and Gilchrist 1994). Firms under the age of 10 are less likely to have an established reputation and paper trail to prove creditworthiness (Rajan and Zingales 1998; Hurst and Pugsley 2011). It is difficult to unambiguously secure loans to firms that have relatively few collateralizable assets, so lenders are more likely to rely on soft information when dealing with these firms (Braun 2005).

${ }^{27}$ In contrast, the effects on non-opaque firms were insignificant and statistically different from the effects on opaque firms (Table A.V). Moreover, opaque firms were less likely to add a treated bank as new relationship bank between 1952 and 1970 (Table A.VI). Opaque firms that already had a treated relationship bank in 1951 were not less likely to keep the treated bank, probably because banking relationships in postwar Germany rarely ended (Table A.VII).
} 


\section{VI.E The Growth of Newly Added Relationship Borrowers of Treated Banks}

I have so far focused on firms that had a treated relationship bank in 1951. Next, I analyze the growth of firms that were newly added as relationship borrowers by the treated banks after 1951 . The treated banks might have provided better financial services to new borrowers and thereby raised their growth. I regress firm employment growth on indicators for whether the firm added a treated bank as relationship bank between 1951 and 1958, in the case of non-stock firms, or between 1951 and 1960, in the case of stock corporations.

Firms that added new relationship banks likely had higher loan demand than other firms. To ensure this does not bias the results, I begin by restricting the sample to firms that increased the number of their relationship banks after 1951. The results suggest that non-stock firms (columns 1 and 2, Table IV) and stock corporations (columns 4 and 5) that newly added a treated relationship bank did not grow faster than other firms.

As an additional check, I use all firms in the sample and include indicators for firms that added a treated bank after 1951, dropped a treated bank after 1951, and never had a treated bank (in or after 1951). The omitted category includes firms that had a treated bank both at the beginning and the end of the sample period. The three coefficients are small and insignificant (columns 3 and 6). ${ }^{28}$ There is also no significant difference between the growth of firms that added a treated bank and firms that never had a treated bank. These results confirm that the treated banks did not raise the growth of newly added borrowers, relative to firms that already had a treated bank in 1951 and relative to firms that never had a treated bank.

\section{VI.F The Growth of Municipalities with Treated Bank Branches}

The final set of main results studies the effect of the reforms at a higher level of aggregation, on municipal employment. The municipality-level analysis includes potential channels of the reforms that the firm-level analysis cannot capture, such as local general equilibrium effects, the reallocation of lending across borrowers, changes in the local banking market, and effects on households. The data sources are described in Appendix E.

I regress annual employment growth in the municipality on an indicator for whether the municipality had a treated bank branch in 1952. Employment growth of municipalities with a treated bank branch was 1.3 percentage points lower between 1951 and 1960 (significant at 5 percent, column 1, Table V). The coefficient remains stable when controlling for federal states, five quantiles of total employment, and the Ruhr area (column 2). As alternative treatment, I use the fraction of firms with a treated relationship bank in the municipality, calculated using the firm data (column 3). The point estimate implies that employment growth was 1.4 percentage points lower in a municipality where

\footnotetext{
${ }^{28}$ The coefficients on firms that added a treated bank are slightly larger in columns 3 and 6 of Table IV, compared to the other columns. This is consistent with a small upward bias stemming from endogenously higher loan demand.
} 
every firm had a treated relationship bank (significant at 10 percent). ${ }^{29}$

Between 1951 and 1956, only banks outside the western zone were treated by the 1952 reform. Employment growth from 1951 to 1956 was 1.2 percentage points lower for municipalities outside the western zone with a treated branch (significant at 10 percent, column 4). The coefficient on municipalities in the western zone is less than one-third of the magnitude and statistically not different from zero. However, it is also not statistically different from the effect on municipalities outside the western zone. There were no pre-trends, as municipality growth from 1947 to 1951 was not associated with having a treated branch (column 5). The baseline result is robust to controlling for a more extensive set of controls (column 6). ${ }^{30}$

The small sample sizes suggest that caution is warranted in interpreting the municipality-level results. Nonetheless, the evidence is consistent with the firm- and bank-level results, providing no evidence of a positive employment effect from the bank consolidations.

\section{Investigating Potential Mechanisms}

Changes in bank size could, in principle, affect the performance of banks and their borrowers through several theoretical mechanisms. In this section, I present suggestive evidence on which mechanisms played an important role after the treated banks consolidated.

Banking As Natural Monopoly: Bank Efficiency and Costs Several theories imply that banking is a natural monopoly (see reviews in Dowd 1992; Bhattacharya and Thakor 1993; Freixas and Rochet 2008). One proposed explanation is that fixed costs are a large part of banks' total costs (Humphrey 1990; Pulley and Humphrey 1993; Hughes and Mester 2013; Kovner et al. 2014). In line with this view, managers of treated banks expressed concerns before the reforms about high fixed costs from employing separate legal departments, separate payment systems, and specialized credit experts for each industry (Der Spiegel 1951; Horstmann 1991). Other explanations for banking as natural monopoly include diversification, the ability to issue large loans, and synergies between lending and underwriting (discussed in detail below).

All these theories predict that the efficiency of banks should improve as banks get bigger. I test the theories by estimating profit and cost efficiency ratios for banks, using the methodology of Berger and Mester (1997). The ratios measure how efficiently a bank generates profits or minimizes costs, conditional on outputs, inputs, and input prices. The closer the efficiency ratio is to one, the

\footnotetext{
${ }^{29} \mathrm{To}$ compare the municipality effects to the firm-level results, I calculate the effect on municipal employment growth that is implied by the firm-level estimates. For non-opaque firms, there was no effect on employment growth. For the average opaque firm, employment growth was 1.6 percentage points lower (column 5, Table III). Roughly 67 percent of employees in the population worked in opaque firms. Thus, in a municipality where every firm had a treated relationship bank, the firm-level estimates imply that employment grew by $1.6 * 0.67=1.1$ percentage points less. This amounts to $1.1 / 1.4=79$ percent of the municipality-level effect in column 3 of Table V. The remaining 21 percent may be due to the effects on households or local spillover effects that harm firm growth (Huber 2018).

${ }^{30}$ I consider the role of local banking competition in Appendix F. Further robustness checks are in Appendix G.
} 
closer a bank is to the best-performing bank in the sample (for details, see Appendix H). I also calculate non-interest costs scaled by assets and revenue. Non-interest costs include fixed costs and other operational expenses. If banking is a natural monopoly, scaled non-interest costs should fall as banks become bigger.

I present financial statistics for the treated banking groups and nine comparable, untreated banks in Table VI. ${ }^{31}$ Average assets before the 1952 reform (column 1), profit and cost efficiency ratios in 1952 (columns 4 and 6), and scaled non-interest costs in 1952 (columns 8 and 10) were similar for treated and untreated banks. This indicates that the treated and untreated banks were comparable in terms of size, efficiency, and costs in 1952.

Between 1952 and 1960, average lending and profits of the treated banks grew more slowly relative to the untreated banks (columns 2 and 3). Average profit and cost efficiency evolved roughly in parallel for treated and untreated banks (columns 4 to 7). Scaled non-interest costs also improved in parallel (columns 8 to 11). ${ }^{32}$ Taken together, the results show that the treated banks did not have profit and cost functions of a natural monopoly and that they did not become more profitable and efficient after consolidating.

Diversification The postwar reforms led to exogenous increases in the number of borrowers served by one treated bank. This increased the diversification of treated banks across states. The canonical theory of bank diversification is by Diamond (1984) and similar predictions appear in Boyd and Prescott (1986), Williamson (1986), and Krasa and Villamil (1992a). Banks diversify by raising the number of borrowers, as long as the growth of borrowers is not perfectly correlated. Diversified banks are less likely to experience simultaneous defaults of a large proportion of borrowers. As a result, diversified banks are less likely to hit capital or liquidity thresholds and less likely to default. Diversified banks also attract more deposits because they are safer (Diamond forthcoming). ${ }^{33}$

In canonical models, both small banks (with few preexisting borrowers) and large banks benefit from adding more borrowers. Consistent with this view, postwar academics and bank managers argued that the postwar reforms would "allow greater diversification of banking risks" and improve banking services to the real economy (Lanner 1951, page 179; Holtfrerich 1995, pages 500, 505).

In contrast, some theories argue that increasing diversification might only help relatively small banks. There are two reasons. First, bank managers might struggle to optimally coordinate the monitoring of many borrowers within their organization. This could mean that large banks experience more disruptions to lending and deposit-taking (Cerasi and Daltung 2000). Second, depositors might find it costly to monitor diversified banks. This could mean that large banks receive fewer deposits

\footnotetext{
${ }^{31}$ Apart from the treated banks, sixteen universal, commercial banks with a branch network existed in 1949 (Hofmann 1949). I was able to locate the 1952 and 1960 annual reports of nine of these untreated banks and of the treated banks. The pre-1952 reports of many treated and untreated banks have not been preserved. The treated banks consolidated in September 1952, so the effect of the 1952 reform on the figures from December 1952 is likely small.

${ }^{32}$ In unreported results, I find that differences between treated and untreated banks in the growth of all the financial statistics were statistically insignificant.

${ }^{33}$ German deposit insurance only started in 1976, so this applies to both bank and non-bank depositors.
} 
(Krasa and Villamil 1992b). In sum, theory is ambiguous about how diversification affects bank stability and deposit inflows. ${ }^{34}$

I find no evidence that fluctuations in assets, lending, and deposits of the treated banking groups were lower after 1952 (Appendix I). This suggests that diversification did not meaningfully stabilize operations of the treated banks. Moreover, the treated banks were not able to raise more deposits after 1952 (Figure II), even though this was their explicit aim (Ahrens 2007). The findings suggest that diversification did not lead to first-order improvements in the performance of the treated banks. The negative effects of further diversification seem to have at least offset any positive effects. ${ }^{35}$

Ultimately, the effects of diversification depend on the comovement of new and existing borrowers, relative to the magnitude of coordination and monitoring frictions. ${ }^{36}$ There was meaningful variation in expected and realized state growth in postwar Germany, including a recession in 1966/67 (Lanner 1951, page 177; Appendix I). This suggests that there was at least some potential to diversify state-level shocks through a national bank. Of course, the effects of diversification might differ in other settings if comovement or frictions are significantly lower.

Avoiding Syndicates for Large Loans Before 1952, the treated banks had to form syndicates with other banks to fund large loans (Wolf 1994). After the reforms, a bigger capital base allowed them to fund large loans on their own.

Theory is ambiguous about how the independent funding of large loans affects borrowers. On the one hand, moral hazard problems are inherent to syndicates, so loan supply might rise once banks can fund loans independently (Holmstrom and Tirole 1997). On the other hand, reputable banks overcome moral hazard problems (as in Diamond 1991) and syndicates offer opportunities for risk sharing (Wilson 1968), so loan supply might not be affected.

I find no evidence that the growth of large borrowers (non-opaque firms or firms above 500 and 1,000 employees) benefited from the consolidations (columns 1 to 6, Table A.VIII). This suggests that the treated banks did not expand loan supply to large borrowers once banks could fund large loans independently. A likely reason is that moral hazard problems for the treated banks were small, consistent with evidence on syndication by reputable banks in Sufi (2007).

Synergies in Cross-Selling The treated banks and most commercial banks operated as universal banks before and after the reforms. This means that banks simultaneously lent to firms and underwrote corporate securities (cross-selling). In many models, the availability and effects of cross-

\footnotetext{
${ }^{34}$ Ramakrishnan and Thakor (1984) and Millon and Thakor (1985) present theories for nondepository financial institutions with similar conclusions.

${ }^{35}$ Evidence from the US suggests that diversification reduced bank market valuations (Goetz et al. 2013) and increased organizational complexity (Correa and Goldberg 2020), even though it lowered stock volatility (Goetz et al. 2016) and funding costs (Levine et al. 2019). This suggests that diversification does not always benefit bank performance, in line with my findings.

${ }^{36}$ To be precise, deposit inflows depend on depositors' expectations about future borrower comovement and frictions after they deposit. In contrast, bank fluctuations depend on realized shocks to borrowers and realized frictions.
} 
selling do not explicitly depend on bank size (Puri 1999; Rajan 2002; Boot and Thakor 1997). However, in some models, synergies from cross-selling are more beneficial when borrowers are large (Kanatas and Qi 2003) or when banks' decision-making structure is centralized (Lóránth and Morrison 2012). The treated banks were more likely to work with large borrowers after the reforms (Table A.VI) and their decision-making structure became more centralized (Horstmann 1991, page 170). As a result, there could have been a positive effect of size on borrowers that relied on cross-selling. I find that firms with both stock capital and bank debt in 1951 did not grow faster after the consolidations (column 7, Table A.VIII). This finding is consistent with models that suggest cross-selling synergies do not change with bank size.

Screening Technologies Bigger banks might use more sophisticated technologies to screen borrowers. For instance, a larger database of customer records might improve statistical analyses and adopting advanced technologies might entail large fixed costs. Improved screening changes bank and borrower outcomes through various mechanisms, which I examine in turn below.

First, improved screening allows banks to issue new loans primarily to borrowers that do not default. This, in turn, reduces banks' loan losses and allows banks to offer cheaper interest rates. As a result of better targeting and cheaper rates, borrowers should be less likely to face liquidation. However, I find that firms with a treated relationship bank in 1951 were not more likely to avoid liquidation than other firms (Table A.IX). The treated banks also did not reduce their loss reserves by more than untreated banks. ${ }^{37}$ These results suggest that the treated banks did not improve their screening of new borrowers.

Second, better screening helps banks to avoid relationships with underperforming borrowers. If this mechanism was important, firms should have been more likely to avoid liquidation after being newly added as relationship borrower by a treated bank, relative to firms not added. Moreover, firms should have been more likely to face liquidation after being dropped by a treated bank, relative to continuing borrowers. I find that the liquidation rates of newly added, dropped, and continuing borrowers were not different from each other (Appendix K). They were also not different from firms that never had a relationship with a treated bank. These results imply that the treated banks did not avoid borrowers with high liquidation rates.

Third, improved screening helps banks to identify firms with high future growth or high productivity. Such high-quality borrowers are more likely to generate positive returns for banks, so banks with better screening technologies should establish more relationships with them. However, labor productivity growth, employment growth, and the level of labor productivity were similar for newly added, dropped, and continuing borrowers of treated banks (Appendix K). This suggests that the treated banks did not become better at identifying high-quality borrowers.

\footnotetext{
${ }^{37}$ From 1952 to 1960 , the treated banks increased reserves per unit of lending by 2.8 pennies on average and the untreated banks by 2.5 pennies on average.
} 
Internal Capital Markets After consolidating, the treated banks were able to shift capital across states through their internal capital markets, rather than relying on interbank markets and central bank clearing (Adler 1949; Wandel 1980; Wolf 1994). But it is not clear whether access to internal capital markets actually changed capital flows. In 1951, Deutsche Bank lawyer Fritz Kempner claimed that internal capital markets would alter cross-state capital flows because internal flows were significantly cheaper (Holtfrerich 1995, page 505). On the contrary, Horstmann (1991) argues that German interbank markets were efficient and that capital flows did not change after 1952.

According to theory in Morgan et al. (2004), changes in capital flows affect the volatility of firm and municipality growth. In several analyses, I show that the volatility and correlation of growth across firms and municipalities did not change after the reforms (Appendix $\mathbf{J}$ ). This suggests that capital flows were unaltered.

In an additional test, I compare German states with a persistent capital account surplus to states with a deficit (Pohl 1971, page 40). If internal capital markets made cross-state capital transfers cheaper, more capital would have flown into surplus states and out of deficit states. As a result, firms with a treated relationship bank in surplus states would have experienced an increase in capital supply and grown more quickly, with the opposite effect in deficit states. However, I find no evidence that the effect of exposure to treated banks differed in deficit states (Tables A.X and A.XI).

The results suggest that cross-state capital flows did not significantly change after the reforms. A likely reason is that interbank markets were well-developed and an adequate substitute for internal capital markets before $1952 .^{38}$

Capital Allocation Theory is ambiguous about whether large banks improve the allocation of capital across borrowers. On the positive side, managers of large banks control a larger stock of capital, relative to managers of state-level banks. This gives them authority to allocate a greater stock of capital to borrowers with the highest marginal product of capital (Stein 1997). In addition, local branch managers in large banks might have greater incentives to produce high-quality information about borrowers, as long as information can be unambiguously recorded and passed on to superiors (Stein 2002).

But there might also be a dark side to capital allocation in large organizations. Managers of large banks might receive incomplete information on borrowers (Williamson 1967), engage in rentseeking (Scharfstein and Stein 2000), and wage internal power battles (Rajan et al. 2000). Problems of asymmetric information and agency might generally be worse in large organizations (Stein 2003). As a result, bigger banks might allocate capital less efficiently.

\footnotetext{
${ }^{38}$ US banking deregulation made state fluctuations smaller and more alike, likely due to increased cross-state capital flows after consolidations (Morgan et al. 2004; Demyanyk et al. 2007; Landier et al. 2017). A reason for the different finding could be that many US banks were very small before deregulation, often operating at the city-level. The citylevel US banks might have found it harder to use interbank markets than the state-level banks in postwar Germany. Gilje et al. (2016) and Cortés and Strahan (2017) also argue that larger banks can access interbank markets more easily, which makes them less dependent on internal capital flows.
} 
Theory suggests that capital allocation is optimal when marginal products of capital are equalized across firms. Hence, better capital allocation means that firms with high marginal product receive relatively more capital (Restuccia and Rogerson 2008; Hsieh and Klenow 2009). Better capital allocation raises the average growth of firms, because the growth increase of firms receiving capital is greater than the growth decrease of firms deprived of capital. If credit allocation improved after the reforms, average growth among firms borrowing from the treated banks should have increased. I find that borrowers of treated banks did not grow faster on average, which implies that capital allocation did not meaningfully improve (Section VI).

At the municipality level, theory suggests that a better allocation of capital generates higher average total factor productivity. As long as municipal labor supply is not perfectly inelastic, the productivity gain should also raise municipal employment growth. Existing evidence suggests that labor supply in Germany municipalities is not inelastic (Decressin and Fatas 1995; Helm 2020; Braun and Weber forthcoming). The negative effect on municipal employment is therefore consistent with the view that capital allocation did not improve (Table V).

Processing Soft Information Opaque borrowers often rely on their banks to incorporate soft information in lending decisions, for example by assessing the character of business owners. In large hierarchies, it is difficult to incentivize employees to generate high-quality soft information and difficult to transfer soft information to decision makers (Berger and Udell 2002; Stein 2002; Brickley et al. 2003). As a result, opaque borrowers of large banks might face lower loan supply.

Indeed, the decision-making procedure on loans likely changed in the treated banks. Before 1952, the state-level banks made decisions about loan applications independently in regionally specialized credit councils (Horstmann 1991, page 170). After the reforms, a more centralized structure took over. The results on opaque firms suggest that opaque borrowers became credit constrained following the consolidations (Table III).

Relationships to Risky Firms I find that treated banks were more likely to add risky firms (with high volatility or high leverage) as new relationship borrowers between 1952 and 1970, relative to less risky firms (Table VII). ${ }^{39}$ What explains greater risk-taking? Bigger banks might take more risks because it allows them to raise profits (Demsetz and Strahan 1997). However, the treated banks did not become more profitable after the reforms (Table VI).

An alternative explanation is that bigger banks face an improved risk-return trade-off (Hughes and Mester 2013). To assess this theory, I study the growth of newly added, risky relationship borrowers of the treated banks. These borrowers did not grow more quickly than other firms after

\footnotetext{
${ }^{39}$ Risky firms that already had a treated relationship bank in 1951 were not more likely to keep the treated bank, probably because banking relationships in postwar Germany rarely ended (Table A.XII). Another way to assess risktaking would be to examine bank leverage. However, changes to accounting regulations in the postwar period make it difficult to construct a consistent series for bank capital (Horstmann 1991).
} 
1952 (Table A.XIII). If borrower growth is correlated with the bank's return to lending, these results suggest that the banks took more risk without gaining a higher return.

A remaining possible explanation is that banks took greater risks because they became "too big to fail" (Freixas 1999; Pais and Stork 2013; Dávila and Walther 2019). Results are consistent with this view. Moreover, anecdotal evidence suggests that the treated banks influenced policy in favor of the financial sector as a whole after the consolidations (Der Spiegel 1971). It is, however, hard to test this theory rigorously given that there were no serious banking crises in the postwar period.

Private Benefits to Bank Managers If the treated banks did not become more profitable or efficient, why did the bank managers favor consolidating? Several theories argue that managers enjoy private benefits from running large firms (Stein 2003). I show that managers of the treated banks indeed benefited in two ways: through greater salaries and media presence.

Between 1952 and 1960, the average annual salary of executives at treated banks increased by 251 percent, compared to 102 percent at untreated banks. The difference is statistically significant at 5 percent. Existing work documents that firm size is correlated with executive pay (Edmans et al. 2017). The finding here suggests that increases in firm size can causally affect executive pay, even without improvements in firm profitability or efficiency.

Moreover, the media coverage of treated banks and their executives increased strongly after the reforms. I calculate the number of times that the name of a treated bank or of a treated bank executive appeared in the German magazine Der Spiegel and the British Financial Times, relative to mentions of the word "bank" or "Germany" (Table VIII). ${ }^{40}$ Figuratively speaking, the results suggest that one bank of size ten receives more media mentions than ten banks of size one combined. Managers might enjoy media presence as an end in itself. Media coverage might also have tangible benefits, as it is correlated with influence on consumer choices and political decisions (Enikolopov and Petrova 2015; Bursztyn and Cantoni 2016).

Taken together, the increases in salaries and media coverage could account for the desire of bank managers to run large firms. The findings are consistent with theories that suggest managers benefit from building corporate "empires."

\section{Discussion of the Results}

In this final section, I discuss what we can learn from the postwar consolidations about the effects of bigger banks.

Interpreting the Magnitude of the Firm-level Estimates Estimates from other studies of bank consolidations are large in absolute terms and lie outside the confidence intervals of my paper. For

\footnotetext{
${ }^{40} \mathrm{I}$ exclude articles from the count that directly report on the postwar banking reforms. Most counted articles either discuss the financial figures of the treated banks or cite the opinion of a bank executive on a particular political or economic issue.
} 
instance, consolidations of relationship banks raised the debt growth of German firms by 3.3 percentage points (Marsch et al. 2007) and lowered the bank debt growth of Italian firms by 7.9 percentage points per year (Di Patti and Gobbi 2007). ${ }^{41}$ This suggests that my quasi-experimental approach leads to meaningfully different conclusions relative to observational studies of bank consolidations. Reforms of the banking sector can, in principle, generate large gains in borrower employment, as examples from other countries reveal. ${ }^{42}$ The German postwar reforms were a comparatively ineffective piece of banking policy in terms of raising the growth of borrowers.

To further gauge the magnitude of the effects, I estimate an elasticity of firm employment with respect to the size of the firm's relationship banks of -0.0009 , with a 95 percent confidence interval from -0.0024 to 0.0005 (Appendix L). The elasticity presents the firm-level effect scaled by the initial shock to bank size. ${ }^{43}$ This might be useful because some models imply that a bigger shock to bank size raises firm growth by more (for example, Diamond 1984). To put the elasticity into context, the reforms increased the size of German firms' relationship banks by 372 percent on average. In comparison, average real assets of FDIC-insured US banks increased by 314 percent from 1950 to $1990 .^{44}$

Insights from the Postwar Reforms The main conclusion of this paper is that increases in bank size do not always improve bank efficiency and borrower growth. This finding stands in contrast to some leading models where scale economies are the reason why banks exist and where bigger banks are always more efficient. In Diamond (1984), for instance, a banking system with a single monopoly bank is socially optimal.

Whether bigger banks benefit or harm borrowers depends on the net impact of several theoretical mechanisms that can affect bank performance. The results of this paper shed light on the net importance of the mechanisms. Some mechanisms might have positively affected borrower growth (spreading fixed costs, issuing large loans, developing synergies, using internal capital markets, more diversification). On the other hand, some mechanisms might have harmed borrower growth (greater complexity, worse processing of soft information). For the average borrower in the data, on net, the mechanisms did not shift growth and no mechanism dominated. However, for opaque borrowers and for municipalities, the harmful mechanisms relating to complexity and soft information processing

\footnotetext{
${ }^{41}$ I find that bank debt growth fell by 0.1 percentage points per year, with a 95 percent confidence interval from -2.7 to 2.6 (column 1, panel B, Table II). Several studies of bank consolidations find negative effects on small borrowers, consistent with my findings on opaque firms, but do not estimate average employment effects on all firms, as I do.

${ }^{42}$ For instance, banking deregulation increased the employment growth of US states by 0.7 percentage points per year (Boustanifar 2014) and total employment in bank-dependent French industries by 23 percent (Bertrand et al. 2007). I find that firm employment growth fell by 0.1 percentage points per year, with a 95 percent confidence interval from -0.8 to 0.6 (column 1, Table I).

${ }^{43}$ The true elasticity might of course be heterogeneous, so that doubling the size of a single-branch lender might have different effects than doubling the size of a large bank. In this regard, recall that the estimates here are about state-level banks that became national banks. After 1957, total assets of every treated bank exceeded 1 percent of German GDP.

${ }^{44}$ Data are from the FDIC. Between 1990 and 2016, average assets of FDIC-insured banks increased by 518.2 percent, and acquisitions raised the average growth per year of Citigroup by 4 percent, of JPMorgan Chase by 10 percent, of Wells Fargo by 13 percent, and of Bank of America by 13 percent (Adams and Driscoll 2018).
} 
dominated, leading to lower employment growth.

More recent data suggest that the mechanisms determining outcomes of opaque borrowers were not only relevant in the 1950s. Just to name a few examples: Relationship banking still influenced real outcomes during the 2008-09 crisis (Chodorow-Reich 2014; Bentolila et al. 2018). Local bankers and branch closures continue to determine the loan supply of firms today (Degryse and Ongena 2005; Nguyen 2019). And US banking deregulation harmed financially constrained borrowers, while it benefited large firms (Berger et al. forthcoming).

The findings of this paper do not imply that increases in bank size can never improve bank efficiency and borrower growth. Returns to scale might have increased since the 1950s because banks have adopted modern information technologies, such as credit scoring (Berger and Mester 1997; Petersen and Rajan 2002; Berger 2003). Moreover, it could be that the operations of a branch remain persistently influenced by having been part of a large institution at some point. The results in this paper would not capture such an effect, since all branches were already part of large banks before the war. While the results do not account for these specific channels, they capture several other mechanisms that are commonly associated with increases in bank size, as discussed above.

\section{Conclusion}

Banking reforms in postwar Germany determined when certain state-level banks were allowed to consolidate into national banks. The reforms provide a rare opportunity to analyze exogenous changes in bank size. I digitize new microdata on German firms and their relationship banks and examine how the bank consolidations affected the growth of banks and their borrowers.

I find no evidence that increases in bank size raised the growth of borrowers. Firms and municipalities with higher exposure to the consolidating banks did not grow faster after their banks consolidated. Opaque (small, young, low-collateral) borrowers of the banks actually experienced lower employment growth after the consolidations. The consolidating banks themselves did not increase lending, profits, or cost efficiency, relative to comparable other banks.

The results show that increases in bank size do not always generate improvements in the performance of banks and their borrowers, and might even harm some firms. The impact of bigger banks is a complex question that depends on the net impact of several mechanisms. Some mechanisms are beneficial and some harmful to borrower growth. The experience from postwar Germany highlights that the beneficial mechanisms are not always powerful enough to outweigh the harmful effects. 


\section{References}

Adams, Robert M. and John C. Driscoll, "How the Largest Bank Holding Companies Grew: Organic Growth or Acquisitions?," 2018.

Adler, Hans A., "The Post-War Reorganization of the German Banking System," Quarterly Journal of Economics, 1949, 63 (3), 322-341.

Ahrens, Ralf, Die Dresdner Bank 1945-1957, Oldenbourg, 2007.

Amiti, Mary and David E. Weinstein, "Exports and Financial Shocks," Quarterly Journal of Economics, 2011, 126 (4), 1841-1877.

Benmelech, Efraim, Carola Frydman, and Dimitris Papanikolaou, "Financial Frictions and Employment During the Great Depression," Journal of Financial Economics, 2019, 133 (3), 541-563.

Bentolila, Samuel, Marcel Jansen, Gabriel Jiménez, and Sonia Ruano, "When Credit Dries Up: Job Losses in the Great Recession," Journal of the European Economic Association, 2018, 16 (3), 650-695.

Berger, Allen N., "The Economic Effects of Technological Progress: Evidence from the Banking Industry," Journal of Money, Credit, and Banking, 2003, 35 (2), 141-176.

— and Gregory F. Udell, "Small Business Credit Availability and Relationship Lending: The Importance of Bank Organisational Structure," The Economic Journal, 2002, 112 (477), F32-F53.

— and Loretta J. Mester, "Inside the Black Box: What Explains Differences in the Efficiencies of Financial Institutions?," Journal of Banking \& Finance, 1997, 21 (7), 895-947.

_ , Anil K. Kashyap, and Joseph M. Scalise, "The Transformation of the US Banking Industry: What a Long, Strange Trip It's Been,” Brookings Papers on Economic Activity, 1995, (2), 55-218.

_ , Anthony Saunders, Joseph M. Scalise, and Gregory F. Udell, "The Effects of Bank Mergers and Acquisitions on Small Business Lending," Journal of Financial Economics, 1998, 50 (2), 187-229.

_ , Leora F. Klapper, and Gregory F. Udell, "The Ability of Banks to Lend to Informationally Opaque Small Businesses," Journal of Banking \& Finance, 2001, 25 (12), 2127-2167.

_ , Nathan H. Miller, Mitchell A. Petersen, Raghuram G. Rajan, and Jeremy C. Stein, "Does Function Follow Organizational Form? Evidence from the Lending Practices of Large and Small Banks," Journal of Financial Economics, 2005, 76 (2), 237-269.

_, Phil Molyneux, and John O.S. Wilson, "Banks and the Real Economy: An Assessment of the Research,” Journal of Corporate Finance, 2019, p. 101513.

_, Rebecca S. Demsetz, and Philip E. Strahan, "The Consolidation of the Financial Services Industry: Causes, Consequences, and Implications for the Future,” Journal of Banking \& Finance, 1999, 23 (2), 135-194.

_ , Ruiyuan Ryan Chen, Sadok El Ghoul, and Omrane Guedhami, "Who Wins and Who Loses From Bank Geographic Deregulation? Analysis of Financially Constrained and Unconstrained Firms," Journal of Corporate Finance, forthcoming.

Bertrand, Marianne, Antoinette Schoar, and David Thesmar, "Banking Deregulation and Industry Structure: Evidence from the French Banking Reforms of 1985," Journal of Finance, 2007, 62 (2), 597-628.

Bhattacharya, Sudipto and Anjan V. Thakor, "Contemporary Banking Theory," Journal of Financial Intermediation, 1993, 3 (1), 2-50.

Biswas, Swarnava Sonny, Fabiana Gómez, and Wei Zhai, "Who Needs Big Banks? The Real Effects of Bank Size on Outcomes of Large US Borrowers," Journal of Corporate Finance, 2017, 46, 170-185.

Boot, Arnoud W. A., "Relationship Banking: What Do We Know?," Journal of Financial Intermediation, 2000, 9 (1), $7-25$.

Boot, Arnoud W.A. and Anjan V. Thakor, "Banking Scope and Financial Innovation," Review of Financial Studies, 1997, 10 (4), 1099-1131.

Boustanifar, Hamid, "Finance and Employment: Evidence from US Banking Reforms," Journal of Banking \& Finance, 2014, 46, 343-354.

Boyd, John H. and Edward C. Prescott, "Financial Intermediary-Coalitions," Journal of Economic Theory, 1986, 38 (2), 211-232.

Braun, Matias, "Financial Contractability and Asset Hardness," 2005. 
Braun, Sebastian and Henning Weber, "How Do Regional Labor Markets Adjust to Immigration? A Dynamic Analysis for Post-war Germany," Journal of International Economics, forthcoming.

Brickley, James A., James S. Linck, and Clifford W. Smith, "Boundaries of the Firm: Evidence from the Banking Industry," Journal of Financial Economics, 2003, 70 (3), 351-383.

Bundesministerium für Arbeit, "Jahreszahlen zur Arbeitsstatistik," 1951. Bonn.

Bursztyn, Leonardo and Davide Cantoni, "A Tear in the Iron Curtain: The Impact of Western Television on Consumption Behavior," Review of Economics and Statistics, 2016, 98 (1), 25-41.

Calomiris, Charles W., "Is Deposit Insurance Necessary? A Historical Perspective," Journal of Economic History, 1990, 50 (2), 283-295.

_ , "The Costs of Rejecting Universal Banking: American Finance in the German Mirror, 1870-1914," in Naomi R. Lamoreaux and Daniel M. G. Raff, eds., Coordination and Information: Historical Perspectives on the Organization of Enterprise, NBER, 1995.

_ , "Gauging the Efficiency of Bank Consolidation During a Merger Wave," Journal of Banking \& Finance, 1999, 23 (2), 615-621.

_ and Jason Karceski, "Is the Bank Merger Wave of the 1990s Efficient? Lessons from Nine Case Studies," in Steven N. Kaplan, ed., Mergers and Productivity, NBER, 2000.

- and Joseph R. Mason, "Consequences of Bank Distress During the Great Depression," American Economic Review, 2003, 93 (3), 937-947.

Canales, Rodrigo and Ramana Nanda, "A Darker Side to Decentralized Banks: Market Power and Credit Rationing in SME Lending," Journal of Financial Economics, 2012, 105 (2), 353-366.

Cerasi, Vittoria and Sonja Daltung, "The Optimal Size of a Bank: Costs and Benefits of Diversification," European Economic Review, 2000, 44 (9), 1701-1726.

Cerqueiro, Geraldo, Hans Degryse, and Steven Ongena, "Rules Versus Discretion in Loan Rate Setting," Journal of Financial Intermediation, 2011, 20 (4), 503-529.

Chodorow-Reich, Gabriel, "The Employment Effects of Credit Market Disruptions: Firm-level Evidence from the 2008-9 Financial Crisis," Quarterly Journal of Economics, 2014, 129 (1), 1-59.

Cole, Rebel A., Lawrence G. Goldberg, and Lawrence J. White, "Cookie Cutter vs. Character: The Micro Structure of Small Business Lending by Large and Small Banks," Journal of Financial and Quantitative Analysis, 2004, 39 (2), 227-251.

Correa, Ricardo and Linda S. Goldberg, "Bank Complexity, Governance, and Risk," 2020.

Cortés, Kristle Romero and Philip E. Strahan, "Tracing out Capital Flows: How Financially Integrated Banks Respond to Natural Disasters," Journal of Financial Economics, 2017, 125 (1), 182-199.

Davies, Richard and Belinda Tracey, "Too Big to Be Efficient? The Impact of Implicit Subsidies on Estimates of Scale Economies for Banks," Journal of Money, Credit and Banking, 2014, 46 (s1), 219-253.

Dávila, Eduardo and Ansgar Walther, "Does Size Matter? Bailouts with Large and Small Banks," Journal of Financial Economics, 2019, 136 (1), 1-22.

Davis, Steven J., John C. Haltiwanger, and Scott Schuh, Job Creation and Destruction, MIT Press, 1998.

Decressin, Jorg and Antonio Fatas, "Regional Labor Market Dynamics in Europe," European Economic Review, 1995, 39 (9), 1627-1655.

Degryse, Hans and Steven Ongena, "Distance, Lending Relationships, and Competition," Journal of Finance, 2005, 60 (1), 231-266.

Demsetz, Rebecca S and Philip E. Strahan, "Diversification, Size, and Risk at Bank Holding Companies," Journal of Money, Credit, and Banking, 1997, 29 (3), 300-313.

Demyanyk, Yuliya, Charlotte Ostergaard, and Bent E. Sørensen, "US Banking Deregulation, Small Businesses, and Interstate Insurance of Personal Income," Journal of Finance, 2007, 62 (6), 2763-2801.

Der Spiegel, "Zerschlagen bis zur Dorfkasse,” 4 July 1951.

_ , "Die Omnipotenten," 18 January 1971.

Deutsche Bundesbank, Deutsches Geld- und Bankwesen in Zahlen 1876-1975, Fritz Knapp Verlag, 1976.

Diamond, Douglas W., "Financial Intermediation and Delegated Monitoring," Review of Economic Studies, 1984, 51 (3), 393-414. 
_ , "Monitoring and Reputation: The Choice Between Bank Loans and Directly Placed Debt," Journal of Political Economy, 1991, 99 (4), 689-721.

Diamond, William, "Safety Transformation and the Structure of the Financial System," Journal of Finance, forthcoming.

Die Zeit, "Graue Zinsen vor dem Ehrengericht," 7 January 1954.

Doerr, Sebastian, Stefan Gissler, José-Luis Peydró, and Hans-Joachim Voth, "From Finance to Extremism: The Real Effects of Germany's 1931 Banking Crisis," 2020.

Dowd, Kevin, "Is Banking a Natural Monopoly?," Kyklos, 1992, 45 (3), 379-392.

Edmans, Alex, Xavier Gabaix, and Dirk Jenter, "Executive Compensation: A Survey of Theory and Evidence," in Benjamin Hermalin and Michael Weisbach, eds., Handbook of the Economics of Corporate Governance, Vol. 1 2017.

Eichengreen, Barry and Albrecht Ritschl, "Understanding West German Economic Growth in the 1950s," Cliometrica, 2009, 3 (3), 191-219.

Eicke, Rudolf, "Aufbau des deutschen Kreditwesens," in Karl Theisinger and Josef Löffelholz, eds., Die Bank: Lehrbuch und Nachschlagewerk des Bank-und Sparkassenwesens 1, Springer, 1952.

Elsas, Ralf and Jan Pieter Krahnen, "Is Relationship Lending Special? Evidence from Credit-file Data in Germany," Journal of Banking \& Finance, 1998, 22 (10), 1283-1316.

Enikolopov, Ruben and Maria Petrova, "Media Capture: Empirical Evidence," in Simon P. Anderson, Joel Waldfogel, and David Strömberg, eds., Handbook of Media Economics, 2015.

Evanoff, Douglas D. and Evren Ors, "The Competitive Dynamics of Geographic Deregulation in Banking: Implications for Productive Efficiency," Journal of Money, Credit and Banking, 2008, 40 (5), 897-928.

Feng, Guohua and Apostolos Serletis, "Efficiency, Technical Change, and Returns to Scale in Large US Banks: Panel Data Evidence from an Output Distance Function Satisfying Theoretical Regularity," Journal of Banking \& Finance, 2010, 34 (1), 127-138.

Focarelli, Dario, Fabio Panetta, and Carmelo Salleo, "Why Do Banks Merge?," Journal of Money, Credit, and Banking, 2002, 34 (4), 1047-1066.

Fohlin, Caroline, "Relationship Banking, Liquidity, and Investment in the German Industrialization," Journal of Finance, 1998, 53 (5), 1737-1758.

Freixas, Xavier, “Optimal Bail Out Policy, Conditionality and Constructive Ambiguity,” 1999.

_ and Jean-Charles Rochet, Microeconomics of Banking, MIT Press, 2008.

Gertler, Mark and Simon Gilchrist, "Monetary Policy, Business Cycles, and the Behavior of Small Manufacturing Firms," Quarterly Journal of Economics, 1994, 109 (2), 309-40.

Gilje, Erik P., Elena Loutskina, and Philip E. Strahan, "Exporting Liquidity: Branch Banking and Financial Integration," Journal of Finance, 2016, 71 (3), 1159-1184.

Goetz, Martin R., Luc Laeven, and Ross Levine, "Identifying the Valuation Effects and Agency Costs of Corporate Diversification: Evidence from the Geographic Diversification of US Banks," Review of Financial Studies, 2013, 26 (7), 1787-1823.

_ , _, and _, "Does the Geographic Expansion of Bank Assets Reduce Risk?," Journal of Financial Economics, 2016, 120 (2), 346-362.

Gorton, Gary, "Banking Panics and Business Cycles," Oxford Economic Papers, 1988, 40 (4), 751-781.

Greenwood, Robin, Samuel G. Hanson, Jeremy C. Stein, and Adi Sunderam, "The Financial Regulatory Reform Agenda in 2017," 2017.

Guinnane, Timothy W., "Delegated Monitors, Large and Small: Germany's Banking System, 1800-1914," Journal of Economic Literature, 2002, 40 (1), 73-124.

Hansen, Ernst Willi, Reichswehr und Industrie, Vol. 24 of Wehrwissenschaftliche Forschungen, Harald Boldt Verlag, 1978.

Harhoff, Dietmar and Timm Körting, "Lending Relationships in Germany: Empirical Evidence from Survey Data," Journal of Banking \& Finance, 1998, 22 (10), 1317-1353.

Helm, Ines, "National Industry Trade Shocks, Local Labour Markets, and Agglomeration Spillovers," Review of Economic Studies, 2020, 87 (3), 1399-1431. 
Herlan, Fritz, "Zinsen und Gebühren," in Hans Pohl, ed., Die Bank: Lehrbuch und Nachschlagewerk des Bank-und Sparkassenwesens, Zweiter Band, Springer Fachmedien, 1952.

Hofmann, Walter, Handbuch des Gesamten Kreditwesens, Knapp, 1949.

Holmstrom, Bengt and Jean Tirole, "Financial Intermediation, Loanable Funds, and the Real Sector," Quarterly Journal of Economics, 1997, 112 (3), 663-691.

Holtfrerich, Carl-Ludwig, "Die Deutsche Bank 1945-1957," in Lothar Gall, Gerald D. Feldman, Harold James, Carl-Ludwig Holtfrerich, and Hans E. Büschgen, eds., Die Deutsche Bank: 1870-1995, C.H. Beck, 1995.

Horstmann, Theo, Die Alliierten und die deutschen Großbanken, Bouvier, 1991.

Hoshi, Takeo and Anil Kashyap, Corporate Financing and Governance in Japan: The Road to the Future, MIT Press, 2004.

Hsieh, Chang-Tai and Peter J. Klenow, "Misallocation and Manufacturing TFP in China and India," Quarterly Journal of Economics, 2009, 124 (4), 1403-1448.

Hubbard, R. Glenn and Darius Palia, "Executive Pay and Performance: Evidence from the US Banking Industry," Journal of Financial Economics, 1995, 39 (1), 105-130.

Huber, Kilian, "Disentangling the Effects of a Banking Crisis: Evidence from German Firms and Counties," American Economic Review, 2018, 103 (3), 868-898.

Hughes, Joseph P. and Loretta J. Mester, "Who Said Large Banks Don't Experience Scale Economies? Evidence from a Risk-return-driven Cost Function," Journal of Financial Intermediation, 2013, 22 (4), 559-585.

_ , Julapa Jagtiani, Loretta J. Mester, and Choon-Geol Moon, "Does Scale Matter in Community Bank Performance? Evidence Obtained by Applying Several New Measures of Performance," Journal of Banking \& Finance, 2019, 106, 471-499.

Humphrey, David B., "Why Do Estimates of Bank Scale Economies Differ?," FRB Richmond Economic Review, 1990, 76 (5), 38-50.

Hurst, Erik and Benjamin Wild Pugsley, "What Do Small Businesses Do?," Brookings Papers on Economic Activity, 2011, (2), 73-142.

Jagtiani, Julapa, Ian Kotliar, and Raman Quinn Maingi, "Community Bank Mergers and Their Impact on Small Business Lending," Journal of Financial Stability, 2016, 27, 106-121.

Jayaratne, Jith and Philip E. Strahan, "The Finance-Growth Nexus: Evidence from Bank Branch Deregulation," Quarterly Journal of Economics, 1996, 111 (3), 639-670.

_ and _ , "Entry Restrictions, Industry Evolution, and Dynamic Efficiency: Evidence from Commercial Banking," Journal of Law and Economics, 1998, 41 (1), 239-274.

Kanatas, George and Jianping Qi, "Integration of Lending and Underwriting: Implications of Scope Economies," Journal of Finance, 2003, 58 (3), 1167-1191.

Kovner, Anna, James Vickery, and Lily Zhou, "Do Big Banks Have Lower Operating Costs?," 2014. FRBNY Economic Policy Review.

Krasa, Stefan and Anne P. Villamil, "Monitoring the Monitor: An Incentive Structure for a Financial Intermediary," Journal of Economic Theory, 1992, 57 (1), 197-221.

_ and _ , "A Theory of Optimal Bank Size," Oxford Economic Papers, 1992, 44 (4), 725-749.

Kreikamp, Hans-Dieter, "Die Entflechtung der I.G. Farbenindustrie A.G. und die Gründung der Nachfolgegesellschaften," Vierteljahreshefte für Zeitgeschichte, 1977, 25 (2).

Landier, Augustin, David Sraer, and David Thesmar, "Banking Integration and House Price Co-movement," Journal of Financial Economics, 2017, 125 (1), 1-25.

Lanner, J., "Changes in the Structure of the German Banking System," Economica, 1951, 18 (70), 169-183.

Levine, Ross, Chen Lin, and Wensi Xie, "Geographic Diversification and Banks’ Funding Costs," 2019.

Liberti, Jose M. and Atif R. Mian, "Estimating the Effect of Hierarchies on Information Use," Review of Financial Studies, 2009, 22 (10), 4057-4090.

Lóránth, Gyöngyi and Alan D Morrison, “Tying in Universal Banks," Review of Finance, 2012, 16 (2), 481-516.

Marsch, Katharina, Christian Schmieder, and Katrin Forster, "Banking Consolidation and Small Business Finance: Empirical Evidence for Germany,” 2007. Bundesbank Series 2 Discussion Paper. 
McCord, Roisin and Edward S. Prescott, "The Financial Crisis, the Collapse of Bank Entry, and Changes in the Size Distribution of Banks," Federal Reserve Bank of Richmond Economic Quarterly, 2014, 100 (1), 23-50.

Menzel, Hans, "Die Mitwirking der Hausbanken bei der Vergebung und Verwaltung öffentlicher Kredite," Untersuchungen über das Spar-, Giro- und Kreditwesen, 1960, 14.

Millon, Marcia H. and Anjan V. Thakor, "Moral Hazard and Information Sharing: A model of Financial Information Gathering Agencies," Journal of Finance, 1985, 40 (5), 1403-1422.

Morgan, Donald P., Bertrand Rime, and Philip E. Strahan, "Bank Integration and State Business Cycles," Quarterly Journal of Economics, 2004, 119 (4), 1555-1584.

Nguyen, Hoai-Luu Q., "Are Credit Markets Still Local? Evidence from Bank Branch Closings," American Economic Journal: Applied Economics, 2019, 11 (1), 1-32.

Pais, Amelia and Philip A. Stork, "Bank Size and Systemic Risk," European Financial Management, 2013, 19 (3), 429-451.

Patti, Emilia Bonaccorsi Di and Giorgio Gobbi, "Winners or Losers? The Effects of Banking Consolidation on Corporate Borrowers," Journal of Finance, 2007, 62 (2), 669-695.

Peek, Joe and Eric S. Rosengren, "Bank Consolidation and Small Business Lending: It's Not Just Bank Size that Matters," Journal of Banking \& Finance, 1998, 22 (6), 799-819.

Petersen, Mitchell A. and Raghuram G. Rajan, "Does Distance Still Matter? The Information Revolution in Small Business Lending," Journal of Finance, 2002, 57 (6), 2533-2570.

Philippon, Thomas, The Great Reversal: How America Gave up on Free Markets, Harvard University Press, 2019.

Pohl, Manfred, Wiederaufbau: Kunst und Technik der Finanzierung 1947-1953. Die ersten Jahre der Kreditanstalt für Wiederaufbau, Fritz Knapp Verlag, 1973.

_ , Hamburger Bankengeschichte, Hase \& Koehler, 1986.

Pohl, Rüdiger, Regionale Leistungsbilanzsalden in integrierten Wirtschaftsräumen, Duncker \& Humblot, 1971.

Pulley, Lawrence B. and David B. Humphrey, "The Role of Fixed Costs and Cost Complementarities in Determining Scope Economies and the Cost of Narrow Banking Proposals," Journal of Business, 1993, pp. 437-462.

Puri, Manju, "Commercial Banks as Underwriters: Implications for the Going Public Process," Journal of Financial Economics, 1999, 54 (2), 133-163.

Qian, Jun Q.J., Philip E. Strahan, and Zhishu Yang, "The Impact of Incentives and Communication Costs on Information Production and Use: Evidence from Bank Lending," The Journal of Finance, 2015, 70 (4), 1457-1493.

Rajan, Raghuram G., "An Investigation into the Economics of Extending Bank Powers," Journal of Emerging Market Finance, 2002, 1 (2), 125-156.

- and Luigi Zingales, "Financial Dependence and Growth,” American Economic Review, 1998, 88 (3), 559-586.

Rajan, Raghuram, Henri Servaes, and Luigi Zingales, "The Cost of Diversity: The Diversification Discount and Inefficient Investment," Journal of Finance, 2000, 55 (1), 35-80.

Ramakrishnan, Ram T.S. and Anjan V. Thakor, "Information Reliability and a Theory of Financial Intermediation," Review of Economic Studies, 1984, 51 (3), 415-432.

Restuccia, Diego and Richard Rogerson, "Policy Distortions and Aggregate Productivity with Heterogeneous Establishments," Review of Economic dynamics, 2008, 11 (4), 707-720.

Rhoades, Stephen A., "The Efficiency Effects of Bank Mergers: An Overview of Case Studies of Nine Mergers," Journal of Banking \& Finance, 1998, 22 (3), 273-291.

Richardson, Gary and William Troost, "Monetary Intervention Mitigated Banking Panics During the Great Depression: Quasi-Experimental Evidence from a Federal Reserve District Border, 1929-1933," Journal of Political Economy, 2009, 117 (6), 1031-1073.

Sapienza, Paola, "The Effects of Banking Mergers on Loan Contracts," Journal of Finance, 2002, 57 (1), 329-367.

Scharfstein, David S. and Jeremy C. Stein, "The Dark Side of Internal Capital Markets: Divisional Rent-seeking and Inefficient Investment," Journal of Finance, 2000, 55 (6), 2537-2564.

Scholtyseck, Joachim, "Die Wiedervereinigung der deutschen Großbanken und das Ende der Nachkriegszeit im Epochenjahr 1957," Bankhistorisches Archiv, 2006, 32 (2), 137-145.

Sharpe, Steven A., "Asymmetric Information, Bank Lending, and Implicit Contracts: A Stylized Model of Customer Relationships," Journal of Finance, 1990, 45 (4), 1069-87. 
Skrastins, Janis and Vikrant Vig, "How Organizational Hierarchy Affects Information Production," 2018.

Statistisches Bundesamt, "Ergebnisse der nichtlandwirtschaftlichen Arbeitsstättenzählung vom 13.9.1950, Teil II," Statistische Berichte, 14 June 1952, IV/15/2. Wiesbaden.

Stein, Jeremy C., "Internal Capital Markets and the Competition for Corporate Resources," Journal of Finance, 1997, $52(1), 111-133$.

_ , "Information Production and Capital Allocation: Decentralized Versus Hierarchical Firms," Journal of Finance, 2002, 57 (5), 1891-1921.

_ , "Agency, Information and Corporate Investment," in G.M. Constantinides, M. Harris, and R. M. Stulz, eds., Handbook of the Economics of Finance, Vol. 12003.

_ , "Regulating Large Financial Institutions," 2013. Speech at the IMF Conference "Rethinking Macro Policy II", 17 April.

Stern, Gary H. and Ron J. Feldman, Too Big to Fail: The Hazards of Bank Bailouts, Brookings Institution Press, 2004.

Stiroh, Kevin J. and Philip E. Strahan, "Competitive Dynamics of Deregulation: Evidence from US Banking," Journal of Money, Credit, and Banking, 2003, 35 (5), 801-828.

Strahan, Philip E. and James P. Weston, "Small Business Lending and the Changing Structure of the Banking Industry," Journal of Banking \& Finance, 1998, 22 (6), 821-845.

Sufi, Amir, "Information Asymmetry and Financing Arrangements: Evidence from Syndicated Loans," Journal of Finance, 2007, 62 (2), 629-668.

Vander Vennet, Rudi, "Cost and Profit Efficiency of Financial Conglomerates and Universal Banks in Europe," Journal of Money, Credit and Banking, 2002, 34 (1), 254-282.

von Alemann, Ulrich, "Modell Montana: Was Hält NRW Zusammen?," 2000. Universität Düsseldorf.

Wandel, Eckhard, Die Entstehung der Bank deutscher Länder, Oldenbourg, 1980.

Wheelock, David C. and Paul W. Wilson, "Do Large Banks Have Lower Costs? New Estimates of Returns to Scale for US Banks," Journal of Money, Credit and Banking, 2012, 44 (1), 171-199.

_ and _, "The Evolution of Scale Economies in US Banking," Journal of Applied Econometrics, 2018, 33 (1), $16-28$.

Williamson, Oliver E., "Hierarchical Control and Optimum Firm Size," Journal of Political Economy, 1967, 75 (2), $123-138$.

Williamson, Stephen D., "Costly Monitoring, Financial Intermediation, and Equilibrium Credit Rationing," Journal of Monetary Economics, 1986, 18 (2), 159-179.

Wilson, Robert, “The Theory of Syndicates,” Econometrica, 1968, pp. 119-132.

Wolf, Herbert, "Die Dreier-Lösung," Bankhistorisches Archiv, 1993, 19 (1), 26-42.

_ , "Nicht Fisch noch Fleisch," Bankhistorisches Archiv, 1994, 20 (1), 28-44.

_ , "Vom Großbankengesetz bis zur "Normalisierung" (1953-1958)," in Hans Pohl, ed., Geschichte der deutschen Kreditwirtschaft seit 1945, Fritz Knapp Verlag, 1998.

Young, Alwyn, "Improved, Nearly Exact, Statistical Inference with Robust and Clustered Covariance Matrices using Effective Degrees of Freedom Corrections," 2016.

Zingales, Luigi, “Towards a Political Theory of the Firm,” Journal of Economic Perspectives, 2017, 31 (3), 113-130. 


\section{Figures}

Figure I: Maps of the postwar banking zones

A: 1947/48-1952

State-level breakup

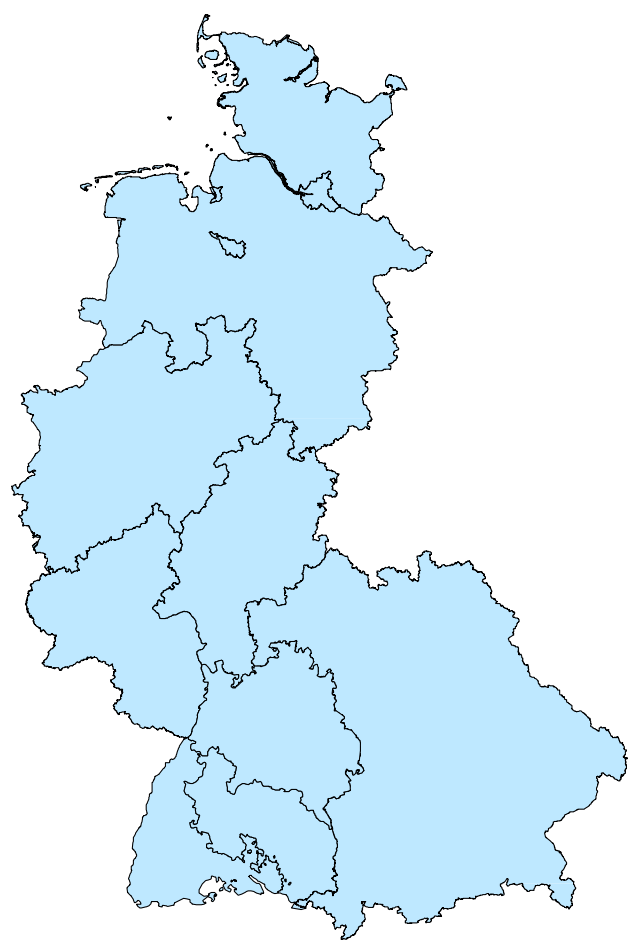

\section{B: 1952-1957}

Three banking zones

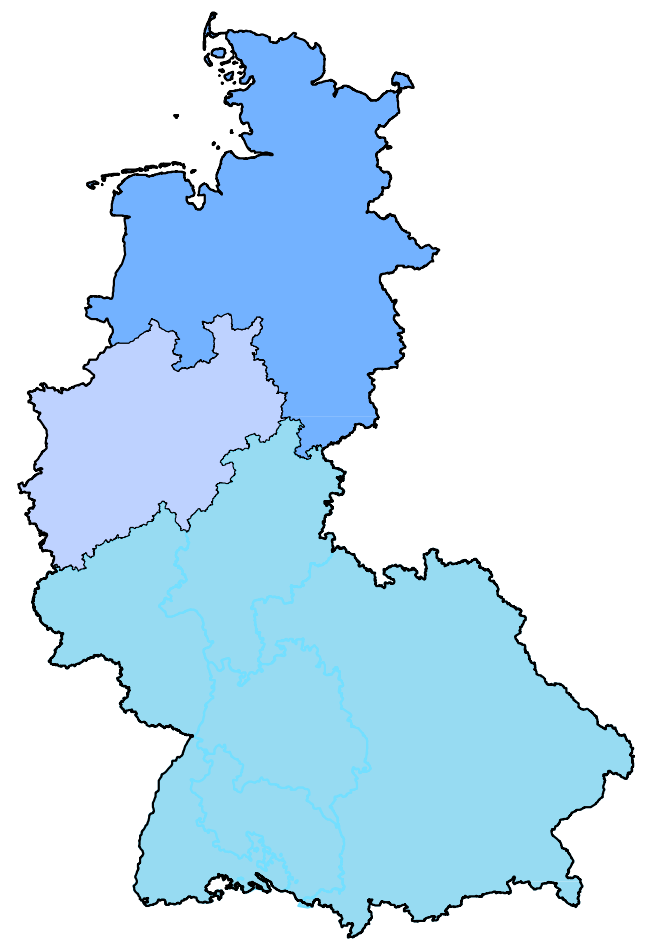

Notes: The figure shows the two phases of the breakup. The postwar breakup limited banks to operating branches only within state borders (panel A). The 1952 reform lifted the state-level restrictions and allowed banks to operate in three regional zones (panel B). The northern zone comprised the northern states, which were under British control. The combined American and French territories formed the southern zone. The western zone was the state of North-Rhine Westphalia, also under British control. The 1957 reform removed all restrictions. 
Figure II: Lending to non-banks and deposits from non-banks

\section{A: Lending to non-banks}

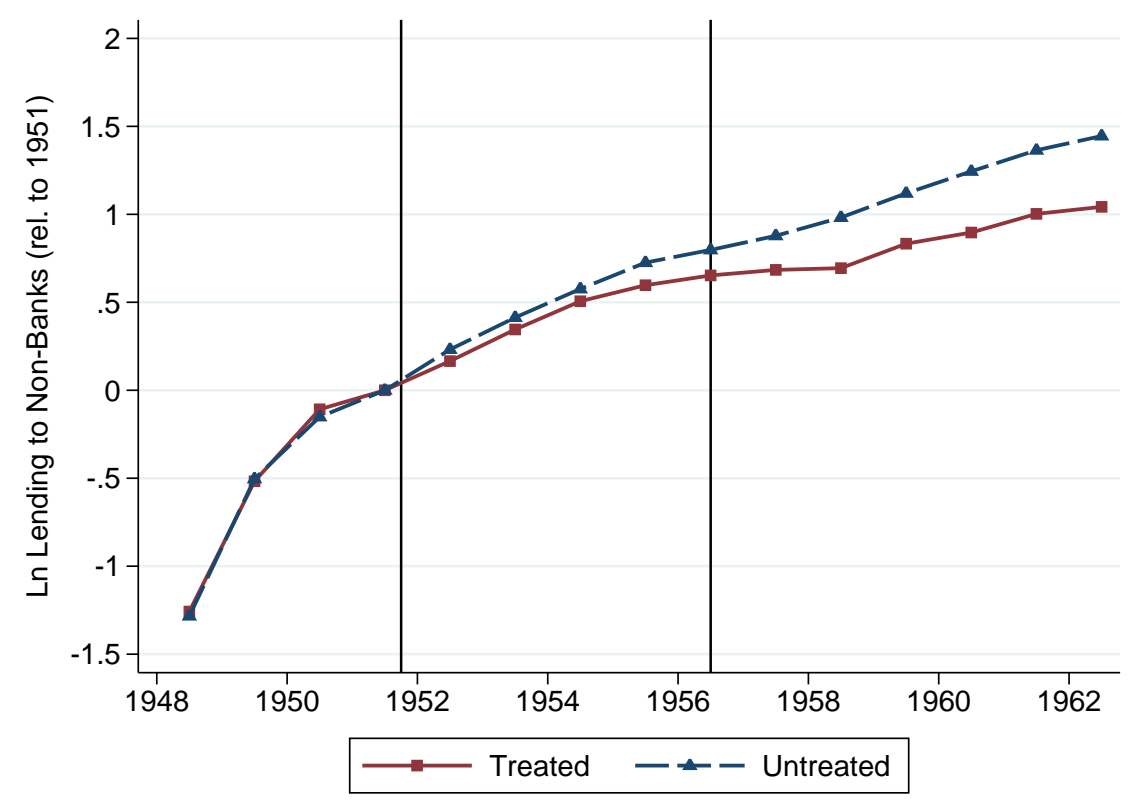

B: Deposits by non-banks

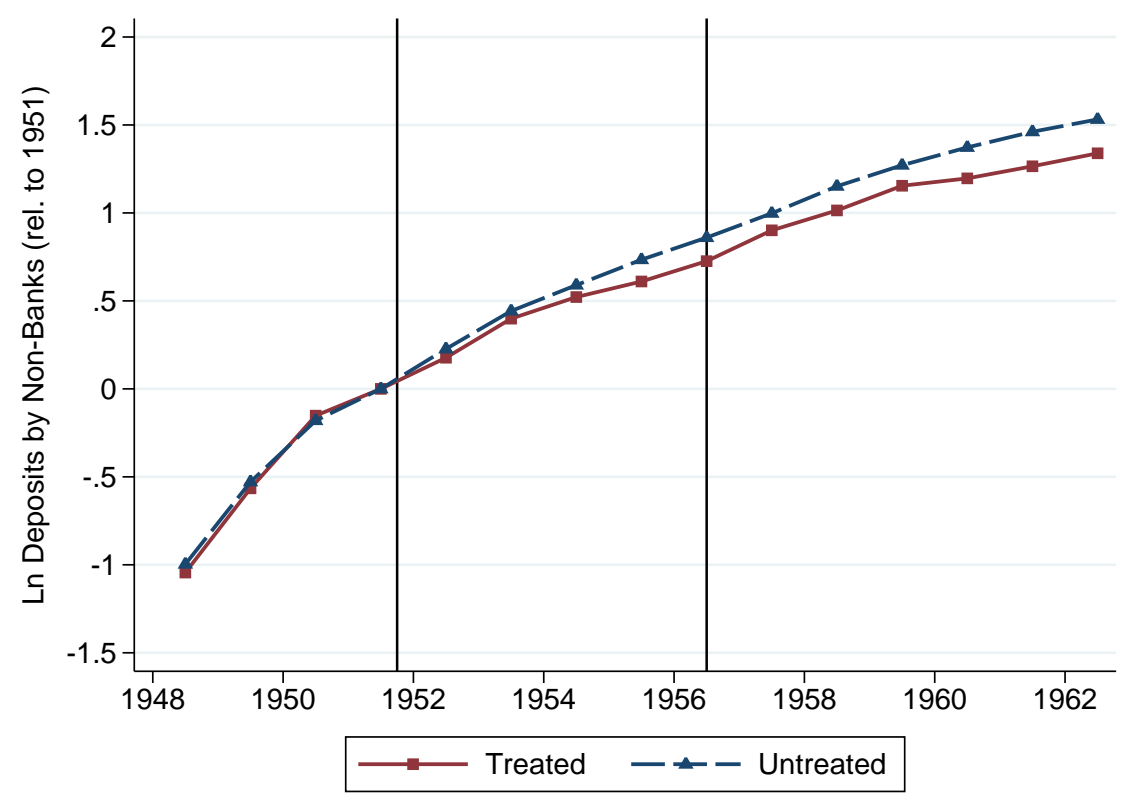

Notes: The data are in real terms, for the December of the given year, and provided by the Deutsche Bundesbank. The treated group includes banks affected by the breakup and subsequent reforms. The untreated group includes all untreated commercial banks. The 1952 reform lifted the state-level restrictions and introduced zonal restrictions. The 1957 reform removed all restrictions. 


\section{Tables}

Table I: Effects on the growth of non-stock firms

\begin{tabular}{|c|c|c|c|c|c|c|c|c|}
\hline & (1) & (2) & (3) & (4) & (5) & (6) & (7) & (8) \\
\hline Outcome & \multicolumn{8}{|c|}{ Employment growth 1951-56 } \\
\hline $\begin{array}{l}\text { Rel. bank treated } \\
\text { in } 1952\end{array}$ & $\begin{array}{l}-0.001 \\
(0.004)\end{array}$ & $\begin{array}{l}-0.001 \\
(0.005)\end{array}$ & $\begin{array}{c}0.001 \\
(0.006)\end{array}$ & $\begin{array}{l}-0.001 \\
(0.006)\end{array}$ & $\begin{array}{c}0.003 \\
(0.006)\end{array}$ & $\begin{array}{c}0.002 \\
(0.010)\end{array}$ & $\begin{array}{l}-0.001 \\
(0.006)\end{array}$ & $\begin{array}{c}0.000 \\
(0.006)\end{array}$ \\
\hline Observations & 1,521 & 1,472 & 353 & 342 & 473 & 464 & 687 & 664 \\
\hline $\mathrm{R}^{2}$ & 0.000 & 0.063 & 0.000 & 0.110 & 0.000 & 0.168 & 0.000 & 0.064 \\
\hline Industry $\mathrm{FE}^{*}$ zone $\mathrm{FE}$ & No & Yes & No & No & No & Yes & No & Yes \\
\hline ln age*zone FE & No & Yes & No & No & No & Yes & No & Yes \\
\hline Size bin $\mathrm{FE}^{*}$ zone FE & No & Yes & No & No & No & Yes & No & Yes \\
\hline Industry FE & No & No & No & Yes & No & No & No & No \\
\hline ln age & No & No & No & Yes & No & No & No & No \\
\hline Size bin FE & No & No & No & Yes & No & No & No & No \\
\hline Firm Type & \multicolumn{2}{|c|}{ Non-Stock } & \multicolumn{2}{|c|}{ Non-Stock } & \multicolumn{2}{|c|}{ Non-Stock } & \multicolumn{2}{|c|}{ Non-Stock } \\
\hline Sample & \multicolumn{2}{|c|}{ Full } & \multicolumn{2}{|c|}{ Focused } & \multicolumn{2}{|c|}{ Exporters } & \multicolumn{2}{|c|}{ Strict states } \\
\hline
\end{tabular}

Notes: The table reports estimates of the effect of having a relationship bank treated in 1952 on the average annual symmetric growth rate of employment, i.e., the symmetric growth rate from 1951 to 1956 divided by 5, the number of years between 1951 and 1956. "Relationship bank treated in 1952" is an indicator for whether the firm had a bank treated in 1952 among its relationship banks in 1951. The controls include fixed effects for four bins of firm employment in 1951 (1-49, 50-249, 250-999, $1000+$ employees), since firm assets are unavailable in the data for non-stock firms. The other controls are explained in Table II. Standard errors are clustered at the level of the firm's county. The sample in columns 1 and 2 includes all non-stock firms with available employment data. The "focused" sample in columns 3 and 4 includes only firms that fulfill all of the following criteria: had a relationship bank that was treated in either 1952 or 1957; in the western zone (North-Rhine Westphalia) or in states bordering the western zone; outside the Ruhr region; not in the coal and steel industry. The sample in columns 5 and 6 includes only firms that exported any of their products. The sample in columns 7 and 8 includes only firms located in the southern states of Baden, Bavaria, Hesse, Rhineland-Palatine, Württemberg-Baden, and Württemberg-Hohenzollern, where the breakup was enforced most strictly. 
Table II: Effects on the growth of stock corporations

\begin{tabular}{|c|c|c|c|c|}
\hline & $(1)$ & $(2)$ & (3) & $(4)$ \\
\hline \multicolumn{5}{|c|}{ Panel A: Employment growth 1951-60 } \\
\hline $\begin{array}{l}\text { Rel. bank treated } \\
\text { in } 1952 / 57\end{array}$ & $\begin{array}{c}0.001 \\
(0.003)\end{array}$ & $\begin{array}{l}-0.001 \\
(0.004)\end{array}$ & $\begin{array}{l}-0.007 \\
(0.010)\end{array}$ & $\begin{array}{l}-0.004 \\
(0.006)\end{array}$ \\
\hline Observations & 821 & 685 & 225 & 356 \\
\hline $\mathrm{R}^{2}$ & 0.000 & 0.112 & 0.251 & 0.177 \\
\hline
\end{tabular}

Panel B: Bank debt growth 1951-60

\begin{tabular}{|c|c|c|c|c|}
\hline $\begin{array}{l}\text { Rel. bank treated } \\
\text { in } 1952 / 57\end{array}$ & $\begin{array}{l}-0.001 \\
(0.013)\end{array}$ & $\begin{array}{c}0.006 \\
(0.017)\end{array}$ & $\begin{array}{c}0.000 \\
(0.021)\end{array}$ & $\begin{array}{c}0.019 \\
(0.026)\end{array}$ \\
\hline Observations & 421 & 421 & 240 & 235 \\
\hline $\mathrm{R}^{2}$ & 0.000 & 0.152 & 0.248 & 0.239 \\
\hline \multicolumn{5}{|c|}{ Panel C: $\Delta \frac{B k \text { debt }}{\text { Assets }} 1951-60$} \\
\hline $\begin{array}{l}\text { Rel. bank treated } \\
\text { in } 1952 / 57\end{array}$ & $\begin{array}{c}0.001 \\
(0.002)\end{array}$ & $\begin{array}{c}0.002 \\
(0.002)\end{array}$ & $\begin{array}{c}0.004 \\
(0.003)\end{array}$ & $\begin{array}{c}0.004 \\
(0.003)\end{array}$ \\
\hline Observations & 421 & 421 & 240 & 235 \\
\hline $\mathrm{R}^{2}$ & 0.002 & 0.125 & 0.185 & 0.247 \\
\hline \multicolumn{5}{|c|}{ Panel D: Revenue per worker growth 1951-60 } \\
\hline $\begin{array}{l}\text { Rel. bank treated } \\
\text { in } 1952 / 57\end{array}$ & $\begin{array}{c}0.004 \\
(0.007)\end{array}$ & $\begin{array}{l}-0.000 \\
(0.007)\end{array}$ & $\begin{array}{c}0.007 \\
(0.016)\end{array}$ & $\begin{array}{l}-0.000 \\
(0.010)\end{array}$ \\
\hline Observations & 345 & 293 & 86 & 165 \\
\hline $\mathrm{R}^{2}$ & 0.002 & 0.303 & 0.516 & 0.369 \\
\hline Industry FE*zone FE & No & Yes & Yes & Yes \\
\hline ln age*zone FE & No & Yes & Yes & Yes \\
\hline ln assets*zone FE & No & Yes & Yes & Yes \\
\hline Firm Type & Stock & Stock & Stock & Stock \\
\hline Sample & Full & Full & $\begin{array}{c}\text { High bank } \\
\text { debt }\end{array}$ & $\begin{array}{c}\text { High } \\
\text { leverage }\end{array}$ \\
\hline
\end{tabular}

Notes: The table reports estimates of the effect of having a treated relationship bank on the growth of stock corporations. Growth in panels A, B, and D is the average annual symmetric growth rate, i.e., the symmetric growth rate from 1951 to 1960 divided by 9, the number of years between 1951 and 1960. The 1951-60 change in $\frac{\text { Bankdebt }}{\text { Assets }}$ is the difference in the ratio of bank debt over assets between 1951 and 1960, divided by 9. "Relationship bank treated in 1952/57" is an indicator for whether the firm had a bank treated in 1952 or 1957 among its relationship banks in 1951. The controls include 18 industry fixed effects, the natural logarithm of firm age, and the natural logarithm of firm assets in 1951. All controls are fully interacted with fixed effects for the northern, western, and southern banking zones that were in existence from 1952 to 1957. Column 3 restricts the sample to stock corporations with above-median ratio of bank debt over assets in 1951. Column 4 includes only stock corporations with a below-median ratio of stock capital over total assets in the sample. Standard errors are clustered at the level of the firm's county. The samples include only stock corporations. 
Table III: Effects on the growth of opaque firms

\begin{tabular}{|c|c|c|c|c|c|c|}
\hline & (1) & (2) & (3) & (4) & (5) & (6) \\
\hline & $\Delta \frac{B k d e b t}{A s s e t s}$ & $\Delta \frac{\text { Cap }}{\text { Assets }}$ & $\begin{array}{l}\text { Empl. } \\
\text { growth }\end{array}$ & $\Delta \frac{B k \text { debt }}{\text { Assets }}$ & \multicolumn{2}{|c|}{$\begin{array}{l}\text { Employment } \\
\text { growth }\end{array}$} \\
\hline Outcome & \multicolumn{2}{|c|}{$1951-60$} & \multicolumn{2}{|c|}{ 1951-60 } & \multicolumn{2}{|c|}{ 1951-56 } \\
\hline $\begin{array}{l}\text { Rel. bank treated } \\
\text { in } 1952 / 57\end{array}$ & $\begin{array}{l}-0.014 \\
(0.005)\end{array}$ & $\begin{array}{c}0.006 \\
(0.004)\end{array}$ & $\begin{array}{c}0.000 \\
(0.015)\end{array}$ & & & \\
\hline $\begin{array}{l}0<\text { Fraction rel. banks } \\
\text { treated in } 1952 / 57 \leq 0.5\end{array}$ & & & & $\begin{array}{l}-0.013 \\
(0.005)\end{array}$ & & \\
\hline $\begin{array}{c}0.5<\text { Fraction rel. banks } \\
\text { treated in } 1952 / 57 \leq 1\end{array}$ & & & & $\begin{array}{l}-0.018 \\
(0.006)\end{array}$ & & \\
\hline $\begin{array}{r}0<\text { Fraction rel. banks } \\
\text { treated in } 1952 \leq 0.5\end{array}$ & & & & & $\begin{array}{l}-0.016 \\
(0.011)\end{array}$ & $\begin{array}{l}-0.030 \\
(0.022)\end{array}$ \\
\hline $\begin{array}{c}0.5<\text { Fraction rel. banks } \\
\text { treated in } 1952 \leq 1\end{array}$ & & & & & $\begin{array}{l}-0.029 \\
(0.015)\end{array}$ & $\begin{array}{l}-0.037 \\
(0.020)\end{array}$ \\
\hline Observations & 74 & 74 & 160 & 74 & 295 & 65 \\
\hline $\mathrm{R}^{2}$ & 0.561 & 0.775 & 0.341 & 0.567 & 0.229 & 0.366 \\
\hline Controls*zone FE & Yes & Yes & Yes & Yes & Yes & No \\
\hline Controls & No & No & No & No & No & Yes \\
\hline Firm type & Stock & Stock & Stock & Stock & Non-Stock & Non-Stock \\
\hline Sample & Opaque & Opaque & Opaque & Opaque & Opaque & $\begin{array}{c}\text { Focused \& } \\
\text { Opaque }\end{array}$ \\
\hline
\end{tabular}

Notes: The outcomes, regressors, and controls for columns 1 to 4 are explained in Table II and for columns 5 and 6 in Table I. Standard errors are clustered at the level of the firm's county. The sample in every column includes only opaque firms. A firm is opaque if in 1951 it had fewer than 50 employees, was younger than 10 years old, or was in the bottom 10 percent of industry asset tangibility (fixed tangible over total assets). 
Table IV: Effects on the growth of newly added relationship borrowers

\begin{tabular}{|c|c|c|c|c|c|c|}
\hline & $(1)$ & $(2)$ & (3) & $(4)$ & $(5)$ & (6) \\
\hline Outcome & \multicolumn{3}{|c|}{ Employment Growth 1951-56 } & \multicolumn{3}{|c|}{ Employment Growth 1951-60 } \\
\hline $\begin{array}{l}\text { Added a bank treated } \\
\text { in } 1952 \text { as rel. bank }\end{array}$ & $\begin{array}{c}0.003 \\
(0.010)\end{array}$ & $\begin{array}{l}-0.001 \\
(0.011)\end{array}$ & $\begin{array}{c}0.011 \\
(0.008)\end{array}$ & & & \\
\hline $\begin{array}{l}\text { Dropped all banks treated } \\
\text { in } 1952 \text { as rel. banks }\end{array}$ & & & $\begin{array}{l}-0.012 \\
(0.010)\end{array}$ & & & \\
\hline $\begin{array}{l}\text { Never had a bank treated } \\
\text { in } 1952 \text { as rel. bank }\end{array}$ & & & $\begin{array}{l}-0.002 \\
(0.006)\end{array}$ & & & \\
\hline $\begin{array}{l}\text { Added a bank treated } \\
\text { in } 1952 / 57 \text { as rel. bank }\end{array}$ & & & & $\begin{array}{c}0.001 \\
(0.007)\end{array}$ & $\begin{array}{l}-0.001 \\
(0.008)\end{array}$ & $\begin{array}{c}0.001 \\
(0.007)\end{array}$ \\
\hline $\begin{array}{l}\text { Dropped all banks treated } \\
\text { in } 1952 / 57 \text { as rel. banks }\end{array}$ & & & & & & $\begin{array}{l}-0.005 \\
(0.008)\end{array}$ \\
\hline $\begin{array}{l}\text { Never had a bank treated } \\
\text { in } 1952 / 57 \text { as rel. bank }\end{array}$ & & & & & & $\begin{array}{l}-0.001 \\
(0.005)\end{array}$ \\
\hline $\begin{array}{l}\text { Observations } \\
\mathrm{R}^{2}\end{array}$ & $\begin{array}{c}320 \\
0.000\end{array}$ & $\begin{array}{c}308 \\
0.231\end{array}$ & $\begin{array}{l}1,472 \\
0.065\end{array}$ & $\begin{array}{c}370 \\
0.000\end{array}$ & $\begin{array}{c}308 \\
0.227\end{array}$ & $\begin{array}{c}681 \\
0.127\end{array}$ \\
\hline $\begin{array}{l}\text { Controls*zone FE } \\
\text { Firm type } \\
\text { Sample }\end{array}$ & $\begin{array}{c}\text { No } \\
\text { Non-Stock } \\
\text { Firms in } \\
\text { no. of rel }\end{array}$ & $\begin{array}{l}\text { Yes } \\
\text { Non-Stock } \\
\text { reased } \\
\text { banks }\end{array}$ & $\begin{array}{c}\text { Yes } \\
\text { Non-Stock } \\
\text { Full }\end{array}$ & $\begin{array}{l}\text { No } \\
\text { Stock } \\
\text { Firms } i \\
\text { no. of } \mathrm{r}\end{array}$ & $\begin{array}{l}\text { Yes } \\
\text { Stock } \\
\text { ased } \\
\text { anks }\end{array}$ & $\begin{array}{l}\text { Yes } \\
\text { Stock } \\
\text { Full }\end{array}$ \\
\hline
\end{tabular}

Notes: "Added a bank treated in 1952/57 as rel. bank" is an indicator for whether a bank treated in either 1952 or 1957 was among the firm's relationship banks in 1958 (for non-stock firms) or 1960 (for stock firms), but no such bank was among the firm's relationship banks in 1951. "Dropped all banks treated in 1952/57 as rel. banks" is an indicator for whether such a bank was among the firm's relationship banks in 1951, but no such bank was among the firm's relationship banks in 1958/60. "Never had a bank treated in 1952/57 as rel. bank" is an indicator for whether such a bank was among the firm's relationship banks neither in 1951 nor in 1958/60. The remaining regressors are defined analogously, but with reference to a bank treated in 1952. The outcome and controls are explained in Table I (for columns 1 to 3) and to Table II (for columns 4 to 6). The samples in columns 1, 2, 4, and 5 include only firms that increased the number of their relationship banks between 1951 and 1958/60. Standard errors are clustered at the level of the firm's county. 
Table V: Effects on municipal employment growth

\begin{tabular}{|c|c|c|c|c|c|c|}
\hline & (1) & (2) & (3) & (4) & (5) & (6) \\
\hline & \multicolumn{6}{|c|}{ Employment growth } \\
\hline Outcome & $1951-60$ & $1951-60$ & $1951-60$ & $1951-56$ & $1947-51$ & $1951-60$ \\
\hline \multirow[t]{2}{*}{ Treated bank branch } & -0.013 & -0.013 & & & 0.019 & -0.014 \\
\hline & $(0.005)$ & $(0.005)$ & & & $(0.017)$ & $(0.004)$ \\
\hline $\begin{array}{l}\text { Fraction of firms with } \\
\text { a treated rel. bank }\end{array}$ & & & $\begin{array}{l}-0.014 \\
(0.008)\end{array}$ & & & \\
\hline Treated bank branch & & & & -0.012 & & \\
\hline outside western zone & & & & $(0.007)$ & & \\
\hline Treated bank branch & & & & -0.004 & & \\
\hline in western zone & & & & $(0.009)$ & & \\
\hline Observations & 79 & 79 & 74 & 91 & 83 & 66 \\
\hline $\mathrm{R}^{2}$ & 0.340 & 0.350 & 0.303 & 0.202 & 0.441 & 0.668 \\
\hline Federal state FE & Yes & Yes & Yes & Yes & Yes & No \\
\hline Size bin FE & Yes & Yes & Yes & Yes & Yes & No \\
\hline Ruhr FE & No & Yes & Yes & Yes & Yes & No \\
\hline Detailed controls*zone FE & No & No & No & No & No & Yes \\
\hline
\end{tabular}

Notes: The table estimates the effect of exposure to treated banks on municipal employment growth. The outcomes are average annual symmetric growth rates of employment in the given period. Treated bank branches were treated in 1952, in 1957, or in both years. Treated bank branches not in the western zone (North-Rhine Westphalia) were treated in 1952 and 1957, while treated bank branches in the western zone were only treated in 1957. The fraction of firms with a treated relationship bank is calculated from the Hoppenstedt firm data for 1951. Size bins are five quantiles of total employees in the municipality. The detailed controls include the full interaction of zonal fixed effects with the following variables: the growth rate from 1947 to 1951; five quantiles for the total number of employees; the share of employment in manufacturing; the share of employment in the primary sector; the share of employment in the public sector; and the employment share of war-time displaced. Standard errors are robust. 


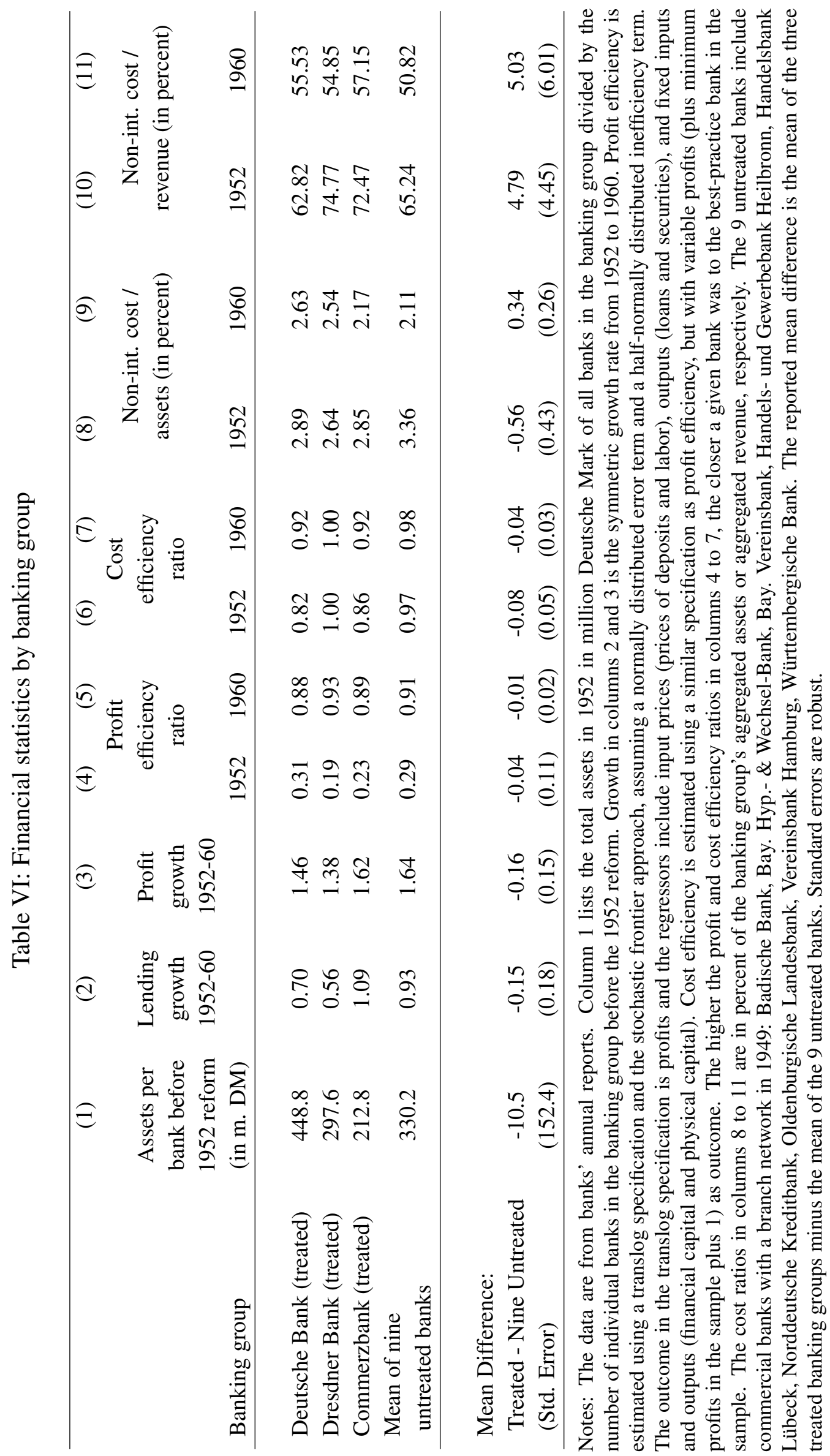


Table VII: New banking relationships with risky firms

\begin{tabular}{|c|c|c|c|c|}
\hline & (1) & (2) & (3) & (4) \\
\hline Outcome & \multicolumn{4}{|c|}{ Fraction of treated rel. banks in 1970} \\
\hline Low volatility & $\begin{array}{l}-0.059 \\
(0.035)\end{array}$ & $\begin{array}{l}-0.058 \\
(0.035)\end{array}$ & & \\
\hline Low leverage $\left(\frac{\text { Cap }}{\text { Assets }} \geq 0.75\right)$ & & & $\begin{array}{l}-0.087 \\
(0.027)\end{array}$ & $\begin{array}{l}-0.094 \\
(0.054)\end{array}$ \\
\hline Medium leverage $\left(0.75>\frac{\text { Cap }}{\text { Assets }} \geq 0.25\right)$ & & & $\begin{array}{c}0.027 \\
(0.033)\end{array}$ & $\begin{array}{c}0.029 \\
(0.031)\end{array}$ \\
\hline $\begin{array}{l}\text { Observations } \\
\mathrm{R}^{2}\end{array}$ & $\begin{array}{c}266 \\
0.033\end{array}$ & $\begin{array}{c}263 \\
0.279\end{array}$ & $\begin{array}{c}164 \\
0.020\end{array}$ & $\begin{array}{c}148 \\
0.545\end{array}$ \\
\hline Opaque firm FE & Yes & Yes & Yes & Yes \\
\hline Controls*zone FE & No & Yes & No & Yes \\
\hline Sample & \multicolumn{4}{|c|}{ Firms without treated rel. bank in 1951} \\
\hline
\end{tabular}

Notes: The outcome is the ratio of the number of treated relationship banks divided by the total number of relationship banks in 1970. A firm has low volatility if the standard deviation of its employment growth from 1946 to 1951 is below the median. Cap / assets is the ratio of stock capital over total assets. A firm is opaque if in 1951 it had fewer than 50 employees or was in the bottom 10 percent of industry asset tangibility (fixed tangible over total assets). The remaining controls are explained in Table I. Standard errors are clustered at the level of the firm's county.

Table VIII: The number of media mentions of treated banks and their managers

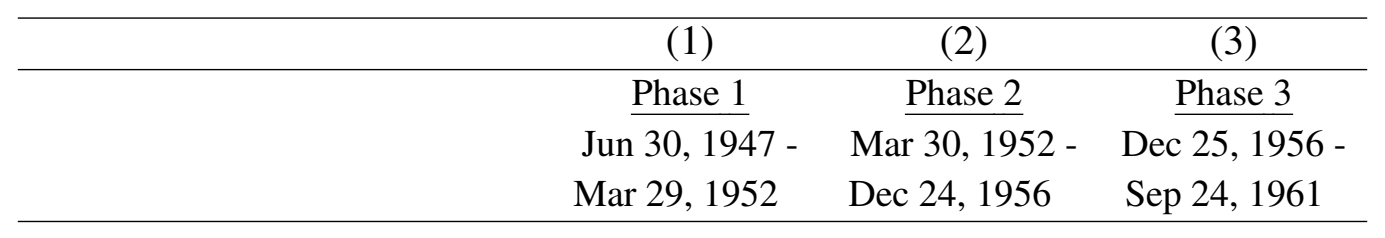

Panel A: Der Spiegel (German weekly news magazine)

\begin{tabular}{lccc}
\hline Name of a treated bank & 15 & 46 & 121 \\
Name of a treated bank manager & 6 & 12 & 20 \\
The word "bank" & 487 & 407 & 479 \\
The word "Deutschland" & 3,145 & 3,086 & 3,062 \\
\multicolumn{4}{c}{ Panel B: Financial Times (British daily newspaper) } \\
\hline \multirow{2}{*}{ Name of a treated bank } & 3 & 261 & 779 \\
Name of a treated bank manager & 2 & 36 & 143 \\
The word "bank" & 22,160 & 30,035 & 37,168 \\
The word "Germany" & 4,065 & 8,129 & 10,311 \\
\hline
\end{tabular}

Notes: The table reports the number of times that the word in the left column was mentioned in an article in the given period. The data are based on the author's calculations from the online archives of Der Spiegel and the Financial Times, accessed August 29, 2017. 


\section{Online Appendix for "Are Bigger Banks Better? Firm-Level Evidence from Germany"}

\section{Appendix A Figures and Tables}

Figure A.I: Lending to non-banks (data until 1972)

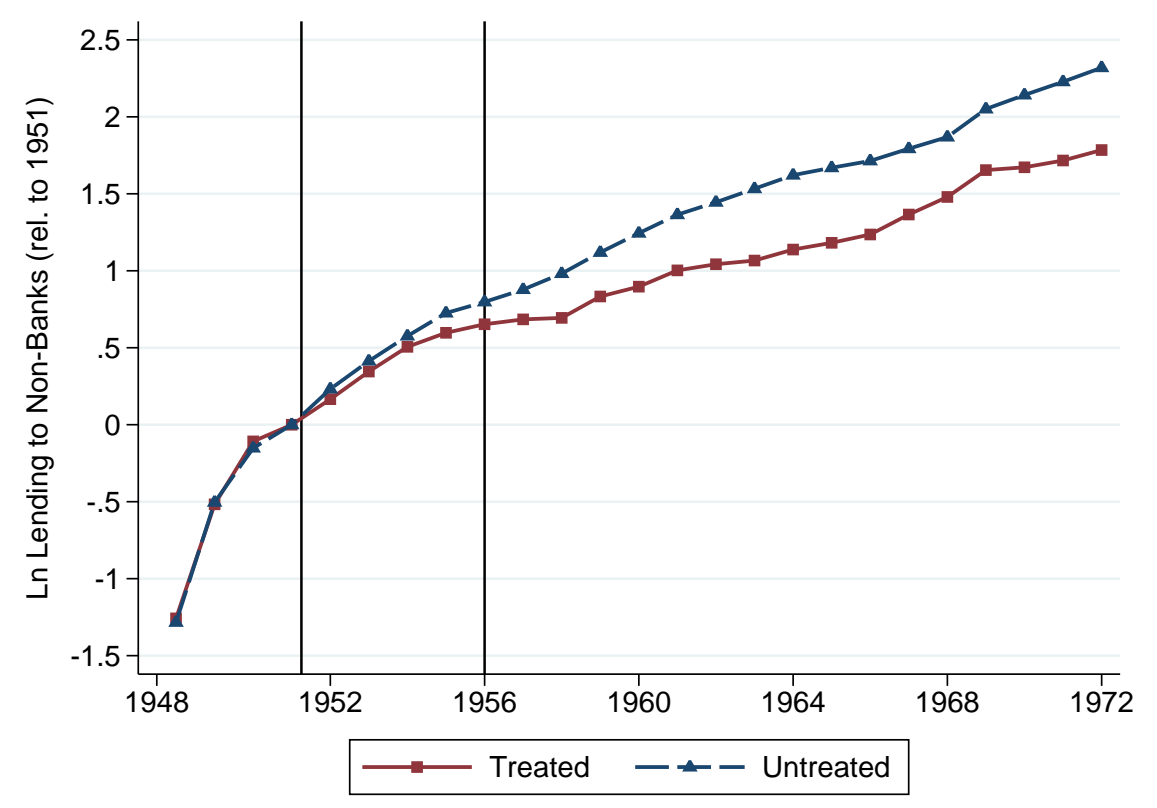

Notes: The figure extends the data in Figure II by ten years. The data are in real terms, for the December of the given year, and provided by the Deutsche Bundesbank. The treated group includes banks affected by the breakup and subsequent reforms. The untreated group includes all untreated commercial banks. The 1952 reform lifted the state-level restrictions and introduced zonal restrictions. The 1957 reform removed all restrictions. 
Figure A.II: Lending to non-banks (treated banks compared to all other banks)

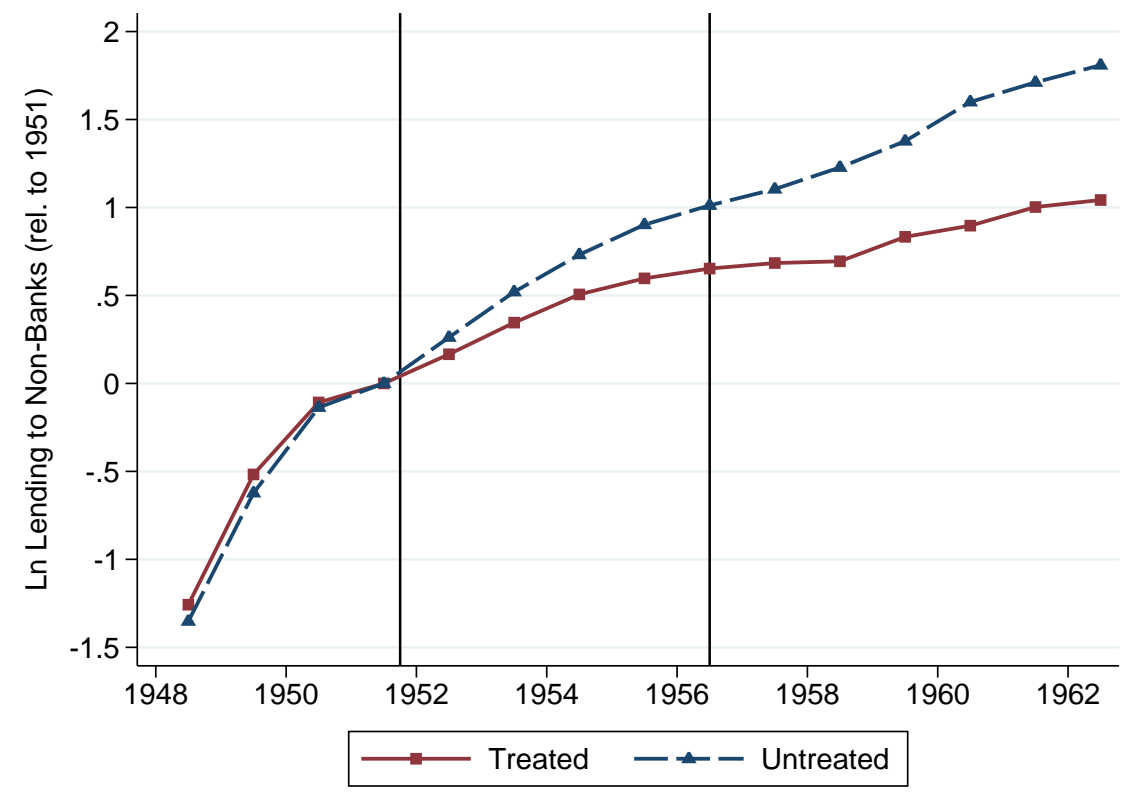

Notes: The figure differs from Figure II by including all other German banks in the untreated group. Figure II uses the other commercial banks as untreated group. The data are in real terms, for the December of the given year, and provided by the Deutsche Bundesbank. 
Figure A.III: Photograph of a page from the 1952 Handbuch der deutschen Aktiengesellschaften

Dr.-Ing. Ludwig Schmitz (seit Oktober 1946), Aursichtsrat: Dr. Alfred Haniel, Hubbelrath, Vors. (im $A,-R$, seit Grindung)

Or. Herbert Dicke, Dusseldort, stelly, Vors. Dr. Krarft von der Tann, Hubbelrath (soit Oktober 1946)

Dipl--Ing: Klaus Liebrecht, KסIn (seit Oktober 1949)

Walter Kaecke, Dusseldorf (seit Mai 1951). AbschluBprufer: Karl Opitz, Wirtschaftsprufer,

Geschäts.jahr: Kalenderjahr.

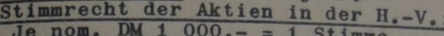

Reingewinnverwendung:

als Gewinnentefar die Aktien bis zu

b) sodann erhält der ausgeschuttet;

b) sods 15 der Setzung zustehtsrat den ihm

Jahresgewinn in Hóhe von 10 von Hundert am

c) der Rest wird nach dem Ermen Hundert;

an die Aktionäre als weiterer Gen der $\mathrm{H},-\mathrm{V}$.

verteilt oder in anderer Weise vermanteil Zahlstelle: Gesellschaftskasse, Ratingen.

\section{Aufbau und Entwicklung}

1925: Grundung unter der Firma "Calor-Elektri zitats-Aktiengesellschaft" in Duisburg. Einge bracht wurden in die Gesellschaft Geschaftsanteile der "Calor-Elektrizitatsgesellschaf m.b.H." in Essen in Hohe von RM 20400 .-.

Die Geselischart befabte sich mit der Herstel lung von Motorschutzschaltern und besaB aup diesem rur die damalige Zeit vollig neuartigein Gebiet eine Relhe Patente.

1930: Umsiediung in großere Werkstatten in Duisburg. Nach und nach erstreckte sich das Fabrikationsprogram Uber das gesamte Gebiet der Niederspannungs- und Schaltapparate und Aniagen.

1933: Ende des Jahres Ubernahm die Gesellschaft ein Werk in Frankfurt (Main), das sich in erster Linie mit der Herstellung von Hochspannungs-Schal tgeráten und Anlagen beraste. Die Fabrikationsstatten blieben getrennt, jedoch wurden Verwaltung und Verkauf zusammengezogen. Die Ubernahme des Werkes Frankrurt wirkte sich sehr gunstig aus, da die Gesellschaft imstande war, als Generalunternehmer auch bei groBen Projekten aufzutreten fur die Lieferung der gesamten schalttechnischen Einrichtung aur dem Gebiete der Hochund Niederspannungs-Schal tgeräte und Anlagen. 1935: Firmenänderung in "Calor-Emag Elektrizitäts-Aktiengesellschaft".

1936: Ankauf eines Anwesens von $69000 \mathrm{qm}$ in Ratingen, da die bisherigen Werkstatten in Duisburg und Frankfurt bei dem standig steigenden Geschätsumfang nicht mehr ausreichte Verlegung des Gesellschaftssitzes von Duisburg nach Ratingen.

1943: Durch umfassende Rationalisierungsmaßnahmen konnte der Umsatz bei verringerter $\mathrm{Be}-$ legschaft trotz kriegsbedingter Schwierigkeiten im Vergleich zum Vorjahr gehalten werden. 1945: Einstellung der Fabrikation in den letzten Wochen vor der Besetzung. Nach der Be setzung langsamer Wiederanlauf des Ratinger Betriebes, beginnend mit Montagearbeiten. Das Frankfurter Werk stand infolge wesentlicher Kriegssohaden und wegen Schwierigkeiten in der Permiterteilung praktisch wahrend des

ganzen Jahres still.
1946: Tellweises Anlaufen des Hauptbetriebes Ratingen; der Betrieb Frankfurt (Main) konnte zwar in kleinem Umeang anlaufen, der Umsatz war jedoch nooh sehr gering.

war jedoch nooh sehr gering.

Einrichtungen; Verstäkung der Belegschaft um

$32 \%$.

1950: 25jahriges Firmenjubilaum.
Besitz- und Betriebsbeschreibunc Fabrikationsbetrieb Frankfurt (Main) Herstellung von Hochspannungs-Schaltgera-
ten. ten. Hauptwerk Ratingen: Herstellung von NiederSchaltanlagen.

Maschinelle Einrichtung: Fur die Herstellung sämtlicher benótigter Einzelteile fur gurgenomen Normteile, Schrauben etc.), und Schaltanlagen.

Kraftanlagen: Strombezug von auswärts.

$$
\text { Bete } 1 \text { i i gung }
$$

Emag Elektrizitats G,m,b.H., Frankfurt (Main). Gegrundet: 16. November 1933.

Kapital : DM 5 000.-

Zweck: Herstellung und Vertrieb von elektrotechnischen Schaltapparaten und Anlazen fur Hoch- und Niederspannungen und sonstize Gegenstände der Elektrizitätsindustrie.

Beteiligung: $100 \%$.

Zugehörigkeit zu Berufsverbänden:

\section{furt (Main)}

Zentralverband d. Elektrotechnischen Industrie rate, Schaltanlagen").

\section{Statistik}

Kapitalentwicklung: Urspr. RM $500000 .-$. 1932: Herabsetzung auf BM $200000 .-$ und wie1940: Kapitalerhöhung $1 \mathrm{t}$. H.- -v. vom 27. November um RM 90000 .- auf $\mathrm{RM} 500000 .-$. 1941: Kapitalberichtigung gem. DAV vom 12 . Juni 1t. BeschluB des A.-R. voim 26. November um $50 \%$ von RM 500 000.- aue RM $750000 .-$. 1951: Lt. H, -V. vom 29. Mai Unstellung von RM 750000 .- auf DM $3000000 .-(1: 4)$.

Heutiges Grundkapital: DM $3000000 .-$ St.-Akt.

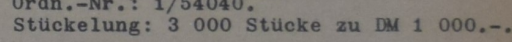
$\frac{\text { Grundbesitz: }}{\text { gesamt: qm }} \frac{1.1 .1939}{69000} \quad \frac{1.1 .1951}{69000} \quad \frac{1.1 .1952}{69000}$ b) bebaut: qm $26000 \quad 26000 \quad 26000$ Belegschaft:

a) Arbeiter: $\quad 1135 \quad 951$

b) Angestelite: $\quad 325 \quad 316$

$\frac{\text { Jahresumsatz: }}{\text { (in Mill. RM/DM) }} \quad \frac{1939}{9} \quad \frac{1950}{14}$

Voraussetzung zur Wertp.-Ber. gegeben. Prufstelle: Rheinisch-Westfalische Bank, Dusseldorf.

Stichtag: i. April 1950.

$\frac{\text { Dividenden: }}{\text { in } \%} \frac{1934-1936}{j e 0} \frac{37}{6} \frac{38}{6} \frac{39}{10} \frac{40-43}{j e 6} \frac{44-50}{j e 0}$

Tag der letzten H.-V.: 5. September 1952.

\section{BILANZ ZUM 31. DEZEABBER 1951 (1950)}

AKTIVA

DM $14 \quad 687 \quad 588 \quad(9 \quad 804 \quad 634)$

Anlagevermögen: Bebaute Grundstücke 230989 (229801), Fabrik- und Verwal tungsgebaude (G) baude 1 (1), im Bau befindliohe Anlagen $24948(-.-)$, Maschinen und masch. Anlagen 
Table A.I: Firm summary statistics

\begin{tabular}{lcccccc}
\hline & Observations & Mean & Std. Dev. & p10 & p50 & p90 \\
\hline & & & & & & \\
& Panel A: Stock corporations & & & & \\
\hline Employment & 1,251 & 1,625 & 5,488 & 23 & 354 & 3,405 \\
Age & 2,182 & 67 & 52 & 26 & 57 & 111 \\
Assets & 1,948 & 23.1 & 132.9 & 0.6 & 3.9 & 37.8 \\
Stock capital / assets & 1,872 & 0.37 & 0.20 & 0.14 & 0.34 & 0.63 \\
Bank debt / assets & 1,208 & 0.10 & 0.11 & 0 & 0.06 & 0.23 \\
Number of relationship banks & 2,188 & 3.18 & 2.08 & 1 & 3 & 6 \\
Relationship bank treated in 1952/57 & 2,188 & 0.68 & 0.47 & 0 & 1 & 1 \\
Relationship bank treated in 1952 & 2,188 & 0.46 & 0.50 & 0 & 0 & 1 \\
Bank debt growth 1951-60 & 421 & 0.01 & 0.15 & -0.22 & 0.03 & 0.21 \\
100.Bankdebt 1951-60 & 421 & -0.11 & 1.39 & -1.77 & -0.11 & 1.79 \\
Emplots & 815 & 0.03 & 0.05 & -0.03 & 0.03 & 0.09 \\
Revenue per worker growth 1951-60 & 344 & 0.05 & 0.05 & 0.00 & 0.04 & 0.10 \\
& & & & & & \\
& Panel B: Non-stock firms & & & & \\
\hline Employment & 1,800 & 559 & 1121 & 91 & 344 & 1,017 \\
Age & 3,494 & 63 & 51 & 16 & 54 & 112 \\
Exporter & 2,593 & 0.39 & 0.49 & 0 & 0 & 1 \\
Number of relationship banks & 3,706 & 2.54 & 1.29 & 1 & 2 & 4 \\
Relationship bank treated in 1952/57 & 3,706 & 0.69 & 0.46 & 0 & 1 & 1 \\
Relationship bank treated in 1952 & 3,706 & 0.41 & 0.49 & 0 & 0 & 1 \\
Employment growth 1951-56 & 1,521 & 0.04 & 0.07 & -0.01 & 0.03 & 0.13 \\
\hline
\end{tabular}

Notes: The data are digitized by hand from Hoppenstedt volumes. The variables in levels are for the year 1951. Assets are in million Deutsche Mark. Growth is the average annual symmetric growth rate, i.e., the symmetric growth rate over the entire period divided by the number of years in the period. $\Delta \frac{100 \cdot \text { Bankdebt }}{\text { Assets }}$ is the change in the percent ratio of bank debt over assets from 1951 to 1960, divided by 9, the number of years between 1951 and 1960. "Relationship bank treated in 1952/57" is an indicator for whether a bank treated in 1952 or 1957 was among the firm's relationship banks in 1951. "Relationship bank treated in 1952" is an indicator for whether a bank treated in 1952 was among the firm's relationship banks in 1951. Exporter is an indicator for whether the firm exported any of its products. 
Table A.II: Characteristics of firms with a treated relationship bank

\begin{tabular}{lcccc}
\hline & $(1)$ & $(2)$ & \multicolumn{2}{c}{$(3)$} \\
\hline \multirow{2}{*}{ Outcome } & \multicolumn{2}{c}{ Rel. bank } & \multicolumn{2}{c}{ Rel. bank } \\
treated in 1952/57 & \multicolumn{2}{c}{ treated in 1952 } \\
\hline \multirow{2}{*}{ Employment } & 0.063 & 0.064 & 0.001 & -0.002 \\
Age & $(0.009)$ & $(0.015)$ & $(0.014)$ & $(0.023)$ \\
& 0.043 & 0.101 & -0.012 & 0.045 \\
Stock capital / assets & $(0.011)$ & $(0.040)$ & $(0.019)$ & $(0.056)$ \\
& & -0.008 & & -0.022 \\
Bank debt / assets & & $(0.050)$ & & $(0.050)$ \\
& & -0.002 & & 0.014 \\
Observations & 3,515 & $(0.018)$ & & $(0.021)$ \\
$\mathrm{R}^{2}$ & 0.040 & 0.078 & 811 & 158 \\
& \multicolumn{3}{c}{ Full } \\
Sample & \multicolumn{3}{c}{0.000} & 0.010 \\
\hline
\end{tabular}

Notes: The data are for the year 1951. The outcome in columns 1 and 2 is an indicator for whether a bank treated in 1952 or 1957 was among the firm's relationship banks in 1951. The outcome in columns 3 and 4 is an indicator for whether a bank treated in 1952 was among the firm's relationship banks in 1951. All regressors are in natural logarithms. Standard errors are clustered at the level of the firm's county.

Table A.III: Testing for pre-trends in firm growth 1949-51

\begin{tabular}{|c|c|c|c|}
\hline & (1) & (2) & (3) \\
\hline Outcome & \multicolumn{3}{|c|}{ Employment Growth 1949-51 } \\
\hline $\begin{array}{l}\text { Rel. bank treated } \\
\text { in } 1952 / 57\end{array}$ & $\begin{array}{c}0.005 \\
(0.011)\end{array}$ & $\begin{array}{c}0.004 \\
(0.023)\end{array}$ & $\begin{array}{c}0.004 \\
(0.023)\end{array}$ \\
\hline $\begin{array}{l}\text { Rel. bank treated } \\
\text { in } 1952\end{array}$ & & $\begin{array}{c}0.001 \\
(0.024)\end{array}$ & $\begin{array}{l}-0.001 \\
(0.024)\end{array}$ \\
\hline $\begin{array}{l}\text { Rel. bank treated } \\
\text { in } 1952 / 57 * \text { Stock Corporation FE }\end{array}$ & & & $\begin{array}{c}0.001 \\
(0.044)\end{array}$ \\
\hline $\begin{array}{l}\text { Rel. bank treated } \\
\text { in } 1952 * \text { Stock Corporation FE }\end{array}$ & & & $\begin{array}{c}0.028 \\
(0.032)\end{array}$ \\
\hline $\begin{array}{l}\text { Observations } \\
\mathrm{R}^{2}\end{array}$ & $\begin{array}{l}1,147 \\
0.146\end{array}$ & $\begin{array}{l}1,147 \\
0.146\end{array}$ & $\begin{array}{l}1,147 \\
0.147\end{array}$ \\
\hline $\begin{array}{l}\text { Controls*zone FE } \\
\text { Sample }\end{array}$ & $\begin{array}{l}\text { Yes } \\
\text { Full }\end{array}$ & $\begin{array}{l}\text { Yes } \\
\text { Full }\end{array}$ & $\begin{array}{l}\text { Yes } \\
\text { Full }\end{array}$ \\
\hline
\end{tabular}

Notes: The outcome is the average annual symmetric growth rate of employment, i.e., the symmetric growth rate from 1949 to 1951 divided by 2 , the number of years between 1949 and 1951. Stock corporation FE is an indicator for stock corporations. The remaining regressors and controls are explained in Table I. The sample contains all stock corporations and non-stock firms with employment data in 1949 and 1951. Standard errors are clustered at the level of the firm's county. 
Table A.IV: Robustness tests for the effect on firm growth

\begin{tabular}{|c|c|c|c|c|c|}
\hline & (1) & $(2)$ & (3) & (4) & $(5)$ \\
\hline Outcome & \multicolumn{5}{|c|}{ Employment Growth 1951-56 } \\
\hline $\begin{array}{l}\text { Rel. bank treated } \\
\text { in } 1952\end{array}$ & $\begin{array}{l}-0.008 \\
(0.006)\end{array}$ & & & $\begin{array}{l}-0.001 \\
(0.004)\end{array}$ & $\begin{array}{l}-0.001 \\
(0.005)\end{array}$ \\
\hline $\begin{array}{r}0<\text { Fraction rel. banks } \\
\text { treated in } 1952 \leq 0.5\end{array}$ & & $\begin{array}{l}-0.003 \\
(0.005)\end{array}$ & & & \\
\hline $\begin{array}{c}0.5<\text { Fraction rel. banks } \\
\text { treated in } 1952 \leq 1\end{array}$ & & $\begin{array}{c}0.002 \\
(0.007)\end{array}$ & & & \\
\hline $\begin{array}{l}\text { Commerzbank rel. } \\
\text { bank treated in } 1952\end{array}$ & & & $\begin{array}{l}-0.001 \\
(0.006)\end{array}$ & & \\
\hline $\begin{array}{l}\text { Deutsche Bank rel. } \\
\text { bank treated in } 1952\end{array}$ & & & $\begin{array}{l}-0.004 \\
(0.004)\end{array}$ & & \\
\hline $\begin{array}{l}\text { Dresdner Bank rel. } \\
\text { bank treated in } 1952\end{array}$ & & & $\begin{array}{c}0.002 \\
(0.004)\end{array}$ & & \\
\hline Observations & 889 & 1,472 & 1,472 & 1,472 & 1,472 \\
\hline $\mathrm{R}^{2}$ & 0.062 & 0.063 & 0.063 & 0.063 & 0.063 \\
\hline Controls*zone FE & Yes & Yes & Yes & Yes & Yes \\
\hline Robustness test & $\begin{array}{l}\text { Excluding } \\
\text { war-related } \\
\text { producers }\end{array}$ & $\begin{array}{c}\text { Treatment: } \\
\text { intensive } \\
\text { margin }\end{array}$ & $\begin{array}{l}\text { Treatment: } \\
\text { three banking } \\
\text { groups }\end{array}$ & $\begin{array}{l}\text { Cluster at } \\
\text { bank level }\end{array}$ & $\begin{array}{c}\text { Young's (2016) } \\
\text { cluster } \\
\text { correction }\end{array}$ \\
\hline
\end{tabular}

Notes: The controls are explained in Table I. Column 1 excludes from the sample firms that the Reichswehr identified as important for armament production (Hansen 1978) and firms in industries that produced war-related products (mining, clothes \& textiles, chemicals \& pharmaceuticals, metals manufacturing, electric \& electronics, production of machinery). Column 2 tests for heterogeneity by firms' intensive margin dependence on treated banks. The two regressors are dummies based on the "fraction relationship banks treated", which is the firm's number of treated relationship banks divided by the firm's total number of relationship banks in 1951. Column 3 tests for heterogeneity by the three treated banking groups. Standard errors in columns 1 to 3 are clustered at the level of the firm's county. Column 4 clusters standard errors at the level of the state-level treated banks (i.e., 31 categories, one for each of the 30 treated state-level banks and one for firms with no treated relationship bank). Column 5 uses the effective degrees of freedom correction for clustered standard errors proposed by Young (2016). 
Table A.V: Effects on opaque firms are statistically different from effects on non-opaque firms

\begin{tabular}{|c|c|c|c|c|}
\hline & $(1)$ & (2) & (3) & $(4)$ \\
\hline Outcome & \multicolumn{2}{|c|}{$\begin{array}{l}\Delta \frac{\text { Bk debt }}{\text { Assets }} \\
1951-60\end{array}$} & \multicolumn{2}{|c|}{$\begin{array}{c}\text { Empl. growth } \\
1951-56\end{array}$} \\
\hline $\begin{array}{l}\text { Rel. bank treated } \\
\text { in } 1952 / 57\end{array}$ & $\begin{array}{c}0.001 \\
(0.002)\end{array}$ & $\begin{array}{c}0.001 \\
(0.002)\end{array}$ & & \\
\hline $\begin{array}{l}\text { Rel. bank treated } \\
\text { in } 1952 / 57 * \text { Opaque firm }\end{array}$ & $\begin{array}{l}-0.009 \\
(0.005)\end{array}$ & & & \\
\hline $\begin{array}{l}0<\text { Fraction rel. banks } \\
\quad \text { treated in } 1952 / 57 \leq 0.5 * \text { Opaque firm }\end{array}$ & & $\begin{array}{l}-0.008 \\
(0.005)\end{array}$ & & \\
\hline $\begin{array}{l}0.5<\text { Fraction rel. banks } \\
\text { treated in } 1952 / 57 \leq 1 * \text { Opaque firm }\end{array}$ & & $\begin{array}{l}-0.012 \\
(0.007)\end{array}$ & & \\
\hline $\begin{array}{l}\text { Rel. bank treated } \\
\text { in } 1952\end{array}$ & & & $\begin{array}{c}0.002 \\
(0.005)\end{array}$ & $\begin{array}{c}0.002 \\
(0.006)\end{array}$ \\
\hline $\begin{array}{l}0<\text { Fraction rel. banks } \\
\text { treated in } 1952 \leq 0.5 * \text { Opaque firm }\end{array}$ & & & $\begin{array}{l}-0.013 \\
(0.009)\end{array}$ & $\begin{array}{l}-0.013 \\
(0.020)\end{array}$ \\
\hline $\begin{array}{l}0.5<\text { Fraction rel. banks } \\
\text { treated in } 1952 \leq 1 * \text { Opaque firm }\end{array}$ & & & $\begin{array}{l}-0.021 \\
(0.012)\end{array}$ & $\begin{array}{l}-0.038 \\
(0.016)\end{array}$ \\
\hline Opaque firm & $\begin{array}{c}0.001 \\
(0.004)\end{array}$ & $\begin{array}{c}0.001 \\
(0.004)\end{array}$ & $\begin{array}{c}0.009 \\
(0.008)\end{array}$ & $\begin{array}{c}0.043 \\
(0.015)\end{array}$ \\
\hline Observations & 288 & 288 & 1,472 & 342 \\
\hline $\mathrm{R}^{2}$ & 0.207 & 0.209 & 0.065 & 0.125 \\
\hline Controls*zone FE & Yes & Yes & Yes & No \\
\hline Controls & No & No & No & Yes \\
\hline Firm type & Stock & Stock & Non-Stock & Non-Stock \\
\hline Sample & Full & Full & Full & Focused \\
\hline
\end{tabular}

Notes: The outcomes, regressors, and controls are explained in Table II (for columns 1 and 2) and to Table I (for columns 3 and 4). Standard errors are clustered at the level of the firm's county. A firm is opaque if in 1951 it had fewer than 50 employees, was younger than 10 years old, or was in the bottom 10 percent of industry asset tangibility (fixed tangible over total assets). 
Table A.VI: Opaque firms were less likely to add treated relationship banks

\section{(1)}

Fraction of treated rel. banks in 1970

Outcome

Opaque firm

$0<$ Employees $<20$

$20 \leq$ Employees $<50$

$0<$ Ind. Tangibility $<0.15$

$0.15 \leq$ Ind. Tangibility $<0.2$

Observations

$\mathrm{R}^{2}$
$-0.056$

$(0.018)$

$-0.054$

(0.020)

$-0.072$

$(0.021)$

$-0.086$

$(0.027)$

$-0.030$

$(0.032)$

$-0.012$

(0.043)

720

720

720

0.010

0.013
Zone and industry FE

Sample
No

Yes

No

Notes: The outcome is the number of treated relationship banks divided by the total number of relationship banks in 1970 . Standard errors are clustered at the level of the firm's county. For the purpose of this table, I classify firms as opaque if in 1951 they had fewer than 50 employees or were in the bottom 10 percent of industry asset tangibility. This definition does not include firms younger than 10 years, because these firms were at least 18 years old in 1970. But in an unreported robustness check, I find that firms founded after 1965 had a significantly lower fraction of treated relationship banks in 1970. Similarly, firms with fewer than 50 employees in 1970 had a significantly lower fraction of treated relationship banks in 1970. 
Table A.VII: No effect on the bank relationships of opaque firms that already had a treated relationship bank

\begin{tabular}{lcc}
\hline & $(1)$ & $(2)$ \\
\hline Outcome & \multicolumn{2}{c}{ Fraction of treated rel. banks in } \\
& 1970 & 1951 \\
\hline Opaque firm & 0.014 & 0.023 \\
& $(0.018)$ & $(0.014)$ \\
Observations & 1,647 & 2,285 \\
$\mathrm{R}^{2}$ & 0.321 & 0.001 \\
& & \\
& & No \\
Fraction of treated rel. banks in 1951 & Yes & Firms with treated rel. bank in 1951 \\
Sample & &
\end{tabular}

Notes: The outcome is the number of treated relationship banks divided by the total number of relationship banks in the given year. A firm is opaque if it has fewer than 50 employees in 1951 or is in the bottom 10 percent of industry asset tangibility (fixed tangible over total assets). Standard errors are clustered at the level of the firm's county.

Table A.VIII: Effects on non-opaque firms, large firms, and firms with both stock capital and bank debt

\begin{tabular}{|c|c|c|c|c|c|c|c|}
\hline & (1) & (2) & (3) & (4) & (5) & (6) & (7) \\
\hline & \multicolumn{7}{|c|}{ Employment Growth } \\
\hline Outcome & $1951-56$ & $1951-60$ & $1951-56$ & $1951-60$ & $1951-56$ & $1951-60$ & $1951-60$ \\
\hline $\begin{array}{l}\text { Rel. bank treated } \\
\text { in } 1952 / 57\end{array}$ & $\begin{array}{c}0.002 \\
(0.005)\end{array}$ & & $\begin{array}{l}-0.009 \\
(0.009)\end{array}$ & & $\begin{array}{l}-0.003 \\
(0.016)\end{array}$ & & $\begin{array}{l}-0.000 \\
(0.008)\end{array}$ \\
\hline $\begin{array}{l}\text { Rel. bank treated } \\
\text { in } 1952\end{array}$ & & $\begin{array}{l}-0.002 \\
(0.005)\end{array}$ & & $\begin{array}{l}-0.002 \\
(0.005)\end{array}$ & & $\begin{array}{c}0.006 \\
(0.007)\end{array}$ & \\
\hline Observations & 1,177 & 525 & 382 & 293 & 125 & 181 & 312 \\
\hline $\mathrm{R}^{2}$ & 0.057 & 0.146 & 0.275 & 0.352 & 0.605 & 0.422 & 0.185 \\
\hline Controls*zone FE & Yes & Yes & Yes & Yes & Yes & Yes & Yes \\
\hline Firm type & Non-Stock & Stock & Non-Stock & Stock & Non-Stock & Stock & Stock \\
\hline Sample & \multicolumn{2}{|c|}{ Not opaque } & Empl. & 500 & \multicolumn{2}{|c|}{ Empl. > 1,000 } & $\begin{array}{c}\text { Both stock capital \& } \\
\text { bank debt in } 1951\end{array}$ \\
\hline
\end{tabular}

Notes: The outcomes, regressors, and controls are explained in Table I (for odd-numbered columns) and Table II (for evennumbered columns). A firm is opaque if in 1951 it had fewer than 50 employees, was younger than 10 years old, or was in the bottom 10 percent of industry asset tangibility (fixed tangible over total assets). The samples in columns 1 and 2 include only non-opaque firms; in columns 3 and 4 firms that had over 500 employees in at least one year between 1951 and 1960; in columns 5 and 6 firms that had over 2,000 employees in at least one year between 1951 and 1960; and in column 7 firms that financed themselves with both stock capital and bank debt in 1951. Standard errors are clustered at the level of the firm's county. 
Table A.IX: Effects on liquidation of firms

\begin{tabular}{lcc}
\hline & $(1)$ & $(2)$ \\
\hline Outcome & $\begin{array}{c}\text { Liquidation } \\
1951-60\end{array}$ & $\begin{array}{c}\text { Liquidation } \\
1960-68\end{array}$ \\
\hline $\begin{array}{c}\text { Rel. bank treated } \\
\text { in 1952/57 }\end{array}$ & $\begin{array}{c}0.007 \\
(0.006)\end{array}$ & $\begin{array}{c}0.010 \\
(0.017)\end{array}$ \\
Observations & 1,346 & 908 \\
$\mathrm{R}^{2}$ & 0.072 & 0.072 \\
\hline Controls*zone FE & Yes & Yes \\
\hline
\end{tabular}

Notes: The outcomes are indicators for whether the firm went into liquidation between 1951 and 1960 (column 1) and between 1960 and 1968 (column 2). The regressor and controls are explained in Table II. Standard errors are clustered at the level of the firm's county.

Table A.X: Effects on firms did not differ in federal states with a persistent capital account deficit

\begin{tabular}{|c|c|c|}
\hline & (1) & $(2)$ \\
\hline & \multicolumn{2}{|c|}{ Employment Growth } \\
\hline Outcome & $1951-56$ & $1951-60$ \\
\hline $\begin{array}{l}\text { Rel. bank treated } \\
\text { in } 1952\end{array}$ & $\begin{array}{l}-0.002 \\
(0.007)\end{array}$ & \\
\hline $\begin{array}{l}\text { Rel. bank treated } \\
\text { in } 1952 * \text { Cap. acc. deficit }\end{array}$ & $\begin{array}{c}0.002 \\
(0.006)\end{array}$ & \\
\hline $\begin{array}{l}\text { Rel. bank treated } \\
\text { in } 1952 / 57\end{array}$ & & $\begin{array}{c}0.003 \\
(0.005)\end{array}$ \\
\hline $\begin{array}{l}\text { Rel. bank treated } \\
\text { in } 1952 / 57 * \text { Cap. acc. deficit }\end{array}$ & & $\begin{array}{l}-0.007 \\
(0.006)\end{array}$ \\
\hline Observations & 1,472 & 685 \\
\hline $\mathrm{R}^{2}$ & 0.063 & 0.115 \\
\hline Controls*zone FE & Yes & Yes \\
\hline Firm type & Non-Stock & Stock \\
\hline
\end{tabular}

Notes: The table tests whether effects were heterogeneous for firms located in German federal states that regularly ran a capital account deficit (indicated by "Cap. acc. deficit," i.e., states that had a persistent net capital outflow, as reported in Pohl 1971, page 40). The other regressors and controls are explained in Table I for column 1 and Table II for column 2. Standard errors are clustered at the level of the firm's county. 
Table A.XI: Effects on municipalities did not differ in federal states with a persistent capital account deficit

\begin{tabular}{lc}
\hline & $(2)$ \\
\hline Outcome & $\begin{array}{c}\text { Empl. growth } \\
1951-60\end{array}$ \\
\hline Treated bank branch & -0.017 \\
& $(0.006)$ \\
Treated bank branch & 0.007 \\
* Cap. acc. deficit & $(0.011)$ \\
Observations & 79 \\
$\mathrm{R}^{2}$ & 0.357 \\
\hline Federal state FE & Yes \\
Size bin FE & Yes \\
Ruhr FE & Yes \\
\hline
\end{tabular}

Notes: The table tests whether effects were heterogeneous for municipalities located in German federal states that regularly ran a capital account deficit (indicated by "Cap. acc. deficit," i.e., states that had a persistent net capital outflow, as reported in Pohl 1971, page 40). The other regressors and controls are explained in Table V. Standard errors are robust.

Table A.XII: No effect on the bank relationships of risky firms that already had a treated relationship bank

\begin{tabular}{|c|c|c|c|c|}
\hline & $(1)$ & $(2)$ & $(3)$ & $(4)$ \\
\hline & \multicolumn{4}{|c|}{ Fraction of treated rel. banks in } \\
\hline Outcome & 1970 & 1970 & 1951 & 1951 \\
\hline Low volatility & $\begin{array}{c}0.017 \\
(0.018)\end{array}$ & & $\begin{array}{l}-0.018 \\
(0.016)\end{array}$ & \\
\hline Low leverage $\left(\frac{\text { Cap }}{\text { Assets }} \geq 0.75\right)$ & & $\begin{array}{c}0.171 \\
(0.124)\end{array}$ & & $\begin{array}{c}0.117 \\
(0.087)\end{array}$ \\
\hline Medium leverage $\left(0.75>\frac{\text { Cap }}{\text { Assets }} \geq 0.25\right)$ & & $\begin{array}{c}0.034 \\
(0.024)\end{array}$ & & $\begin{array}{c}0.025 \\
(0.023)\end{array}$ \\
\hline Observations & 569 & 377 & 767 & 534 \\
\hline $\mathrm{R}^{2}$ & 0.398 & 0.462 & 0.141 & 0.146 \\
\hline Controls*zone FE & Yes & Yes & Yes & Yes \\
\hline Opaque firm FE & Yes & Yes & Yes & Yes \\
\hline Fraction of treated rel. banks in 1951 & Yes & Yes & No & No \\
\hline Sample & \multicolumn{4}{|c|}{ Firms with treated rel. bank in 1951} \\
\hline
\end{tabular}

Notes: The outcome is the ratio of the number of treated relationship banks divided by the total number of relationship banks in the given year. A firm has low volatility if the standard deviation of its employment growth from 1946 to 1951 is below the median. Cap / assets is the ratio of stock capital over total assets. A firm is opaque if it has fewer than 50 employees in 1951 or is in the bottom 10 percent of industry asset tangibility (fixed tangible over total assets). A firm is opaque if it has fewer than 50 employees in 1951, is younger than 10 years old in 1952, or is in the bottom 10 percent of industry asset tangibility (fixed tangible over total assets). The controls are explained in Table I. Standard errors are clustered at the level of the firm's county. 


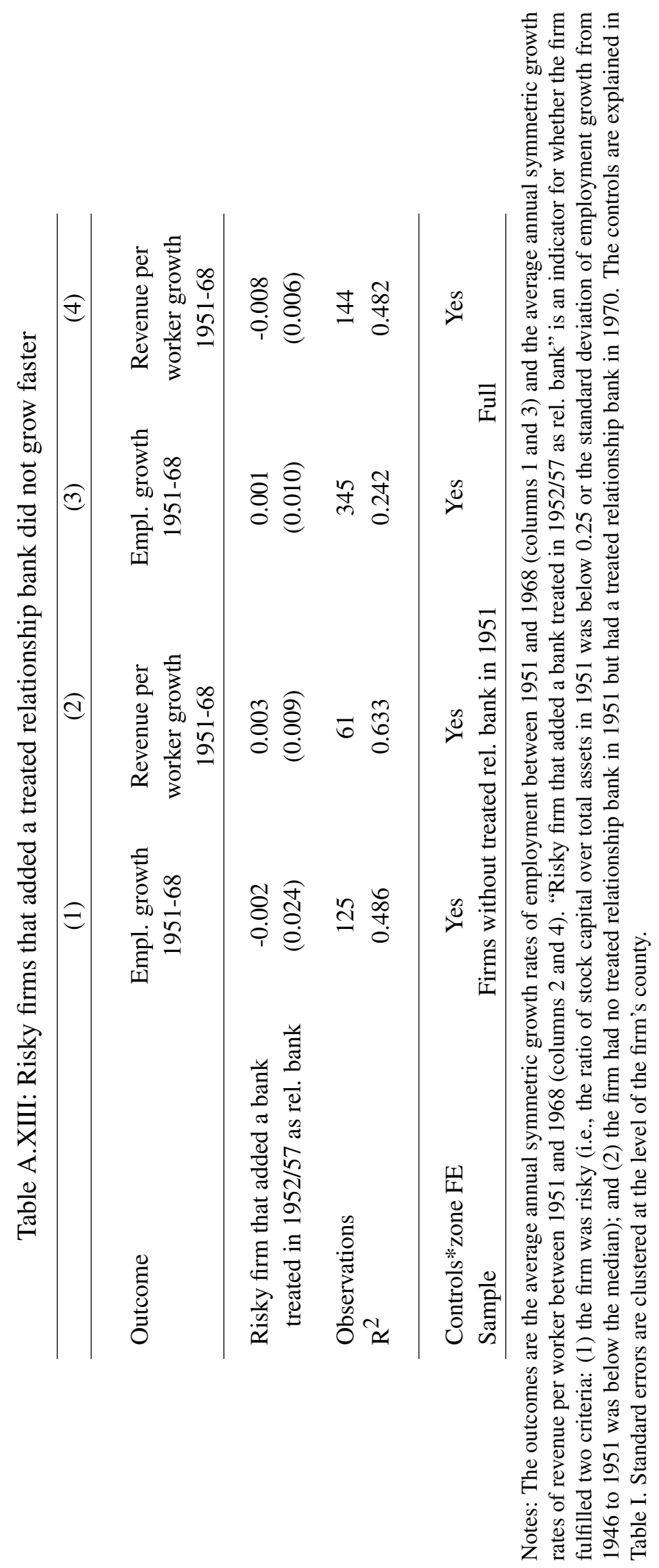


Table A.XIV: Using 1940 relationship banks as treatment indicators

\begin{tabular}{|c|c|c|c|c|}
\hline & (1) & (2) & (3) & (4) \\
\hline & \multicolumn{4}{|c|}{ Employment Growth } \\
\hline Outcome & $1949-51$ & $1951-56$ & $1949-51$ & $1951-56$ \\
\hline $\begin{array}{l}\text { Rel. bank (as of 1940) } \\
\text { treated in } 1952\end{array}$ & $\begin{array}{c}0.001 \\
(0.031)\end{array}$ & $\begin{array}{l}-0.001 \\
(0.010)\end{array}$ & $\begin{array}{c}0.027 \\
(0.076)\end{array}$ & $\begin{array}{l}-0.061 \\
(0.013)\end{array}$ \\
\hline Observations & 182 & 370 & 25 & 51 \\
\hline $\mathrm{R}^{2}$ & 0.374 & 0.157 & 0.175 & 0.338 \\
\hline Controls*zone FE & Yes & Yes & No & No \\
\hline Basic Controls & No & No & Yes & Yes \\
\hline Sample & \multicolumn{2}{|c|}{ Full } & \multicolumn{2}{|c|}{ Opaque } \\
\hline
\end{tabular}

Notes: The outcomes are the average annual symmetric growth rates of employment in the given period. "Relationship bank (as of 1940) treated in 1952" is an indicator for whether one of the firm's 1940 relationship banks was treated in the first reform of 1952. A firm is opaque if in 1951 it had fewer than 50 employees, was younger than 10 years old, or was in the bottom 10 percent of industry asset tangibility (fixed tangible over total assets). The controls*zone FE correspond to the standard controls from Table I. The small sample sizes in columns 3 and 4 necessitate the use of a reduced set of controls. The controls in columns 3 and 4 include a fixed effect for manufacturing firms, fixed effects for four bins of firm employment in 1951 (1-49, 50-249, 250-999, $1000+$ employees), and the natural logarithm of the firm's age. Standard errors are clustered at the level of the firm's county.

Table A.XV: Were the firm-level effects stronger in municipalities where few firms had a treated relationship bank?

\begin{tabular}{|c|c|c|c|}
\hline & (1) & (2) & (3) \\
\hline Outcome & \multicolumn{3}{|c|}{ Employment Growth 1951-56 } \\
\hline Definition of low-treatment municipality & $<10 \%$ & $<20 \%$ & $<30 \%$ \\
\hline \multirow{2}{*}{$\begin{array}{l}\text { Rel. bank treated } \\
\text { in } 1952\end{array}$} & -0.002 & 0.002 & 0.002 \\
\hline & $(0.006)$ & $(0.006)$ & $(0.006)$ \\
\hline \multirow[t]{2}{*}{ Low-treatment municipality } & -0.001 & 0.008 & 0.010 \\
\hline & $(0.008)$ & $(0.009)$ & $(0.008)$ \\
\hline \multirow{2}{*}{$\begin{array}{l}\text { Rel. bank treated } * \\
\text { Low-treatment municipality }\end{array}$} & 0.006 & -0.009 & 0.004 \\
\hline & $(0.017)$ & $(0.014)$ & $(0.014)$ \\
\hline \multirow{2}{*}{$\begin{array}{l}\text { Observations } \\
\mathrm{R}^{2}\end{array}$} & 1,472 & 1,472 & 1,472 \\
\hline & 0.063 & 0.064 & 0.065 \\
\hline Controls*zone FE & Yes & Yes & Yes \\
\hline
\end{tabular}

Notes: Low-treatment municipality is an indicator for firms located in municipalities where the fraction of firms with a treated relationship bank in 1951 is below the percentage indicated in the first row of the table. The outcome, remaining regressors, and controls are explained in Table I. Standard errors are clustered at the level of the firm's county. 


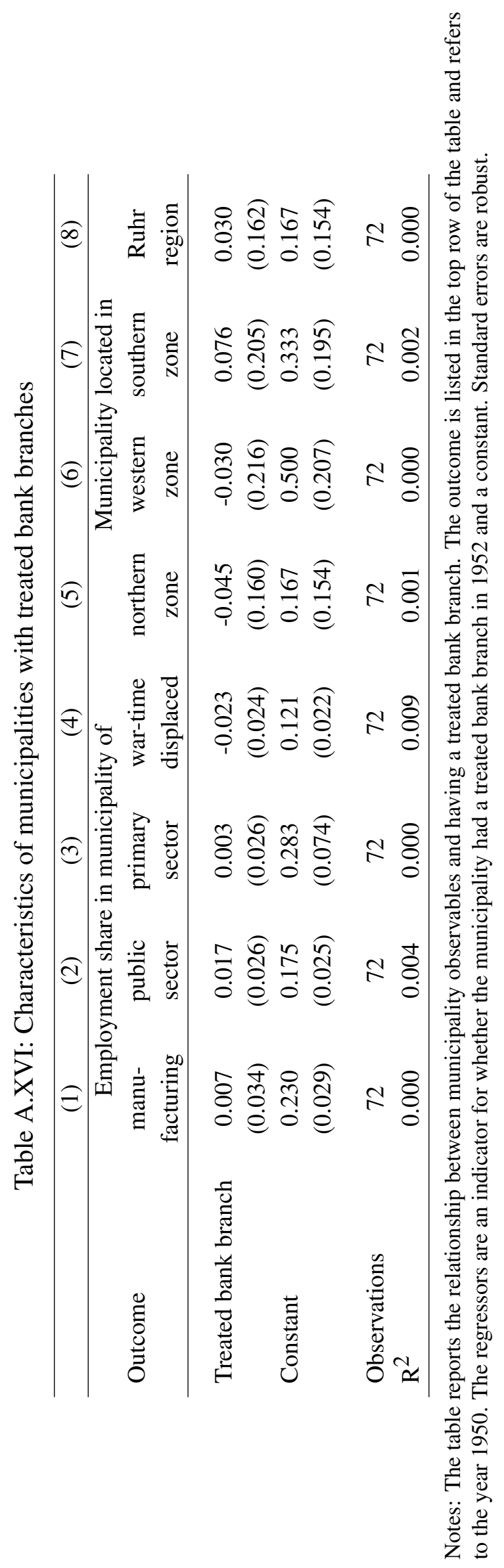




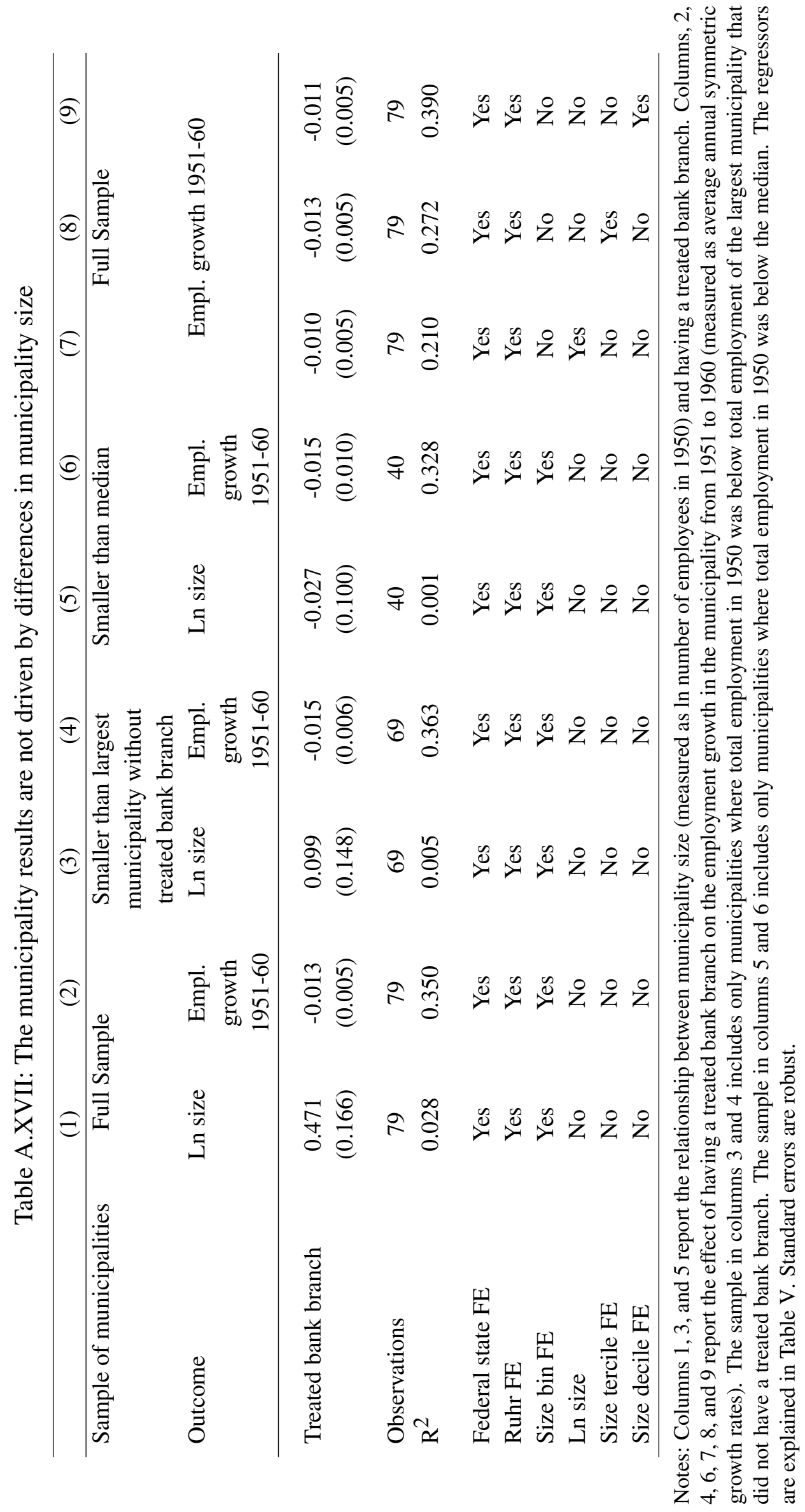


Table A.XVIII: Effects on the volatility of bank balance sheet figures

\begin{tabular}{|c|c|c|c|c|c|c|}
\hline & (1) & (2) & (3) & (4) & (5) & (6) \\
\hline & \multicolumn{6}{|c|}{ Conditional absolute deviation in growth of } \\
\hline Outcome & Assets & Lending & Deposits & Assets & Lending & Deposits \\
\hline Treated banking group * & 0.010 & 0.026 & 0.038 & 0.010 & 0.027 & 0.040 \\
\hline Post 1952 & $(0.009)$ & $(0.019)$ & $(0.045)$ & $(0.009)$ & $(0.020)$ & $(0.046)$ \\
\hline Treated banking group * & -0.002 & 0.010 & -0.014 & -0.003 & 0.009 & -0.015 \\
\hline Post 1957 & $(0.005)$ & $(0.007)$ & $(0.012)$ & $(0.005)$ & $(0.008)$ & $(0.012)$ \\
\hline Treated banking group $*$ & & & & 0.002 & 0.004 & 0.013 \\
\hline Recession 1966/67 & & & & $(0.007)$ & $(0.008)$ & $(0.010)$ \\
\hline Observations & 287 & 308 & 308 & 287 & 308 & 308 \\
\hline $\mathrm{R}^{2}$ & 0.380 & 0.416 & 0.463 & 0.380 & 0.416 & 0.464 \\
\hline Banking group FE and time FE & Yes & Yes & Yes & Yes & Yes & Yes \\
\hline
\end{tabular}

Notes: The data are from the Deutsche Bundesbank and aggregated at the level of seven different banking groups. The groups are: the treated banks, untreated commercial banks, private banks, savings banks, cross-regional cooperative banks, regional cooperative banks, and mortgage banks. The data include two observations per year from 1948 to 1970 for each banking group (asset data from 1949). To calculate the outcome, I regress the change in the given financial variable $C_{g t}$ (growth in assets, lending, or deposits for banking group $g$ in year $t)$ on a full set of fixed effects for banking groups $\left(\alpha_{g}\right)$ and for time $\left(\alpha_{t}\right)$ : $C_{g t}=\alpha_{g}+\alpha_{t}+\varepsilon_{g t}$. The absolute value of the residual $\left(\left|\varepsilon_{g t}\right|\right)$ is the outcome variable, a measure of the fluctuation in growth. Intuitively, it is the absolute deviation of a given banking group's growth relative to the average growth of all banking groups in that year and relative to the given banking group's average growth over all years. In columns 1 to 3, I regress the fluctuation measure on indicators for the periods after the 1952 reform (post 1952) and after the 1957 reform (post 1957), interacted with an indicator for the treated banking group. In columns 4 to 6, I add an indicator for the recession years 1966/67, interacted with the treated banking group indicator. All specifications control for time fixed effects and banking group fixed effects. Standard errors are clustered at the level of the banking group. 
Table A.XIX: Effects on the volatility of firm growth

\begin{tabular}{lcccc}
\hline & $(1)$ & $(2)$ & $(3)$ & $(4 \mathrm{~s})$ \\
\hline \multirow{2}{*}{ Outcome } & \multicolumn{2}{c}{ Conditional absolute } & deviation in growth of firm \\
Employment & \multicolumn{2}{c}{ Revenue } \\
\hline Rel. bank treated in $1952 *$ post 1952 & 0.006 & 0.006 & 0.006 & -0.000 \\
& $(0.008)$ & $(0.008)$ & $(0.008)$ & $(0.012)$ \\
Rel. bank treated in 1957 * post 1957 & -0.005 & -0.007 & 0.008 & 0.014 \\
& $(0.007)$ & $(0.007)$ & $(0.010)$ & $(0.011)$ \\
Observations & 11,750 & 8,628 & 7,034 & 4,717 \\
$\mathrm{R}^{2}$ (within firm) & 0.000 & 0.050 & 0.055 & 0.107 \\
Mean (std. dev.) of outcome & $0.073(0.106)$ & $0.111(0.140)$ \\
Firm FE and year FE & Yes & Yes & Yes & Yes \\
Industry FE*zone FE*(post 1952, post 1957) & No & Yes & No & Yes \\
ln age*zone FE*(post 1952, post 1957) & No & Yes & No & Yes \\
Size bin FE*zone FE*(post 1952, post 1957) & No & Yes & No & Yes \\
\hline
\end{tabular}

Notes: To calculate the outcome, I use a first stage regression of the annual symmetric growth rate on firm and year fixed effects. The absolute value of the residual from the first stage regression is the outcome variable in the specifications reported in the table. Intuitively, it measures the absolute deviation of a given firm's growth relative to the average growth of all firms in that year and relative to the given firm's average growth over all years. I regress the fluctuation measure on indicators for the periods after the 1952 reform (post 1952) and after the 1957 reform (post 1957), interacted with indicators for whether a firm's relationship bank was treated in the given year. The remaining regressors and controls are explained in Table I. The data are from an unbalanced firm panel from 1946 to 1970. Standard errors are clustered at the level of the firm's county.

Table A.XX: Effects on the standard deviation of firm growth

\begin{tabular}{lcccccc}
\hline & $(1)$ & $(2)$ & $(3)$ & $(4)$ & $(5)$ & $(6)$ \\
\hline Outcome & \multicolumn{7}{c}{$\begin{array}{c}\text { Difference in std. dev. } \\
\text { of revenue growth }\end{array}$} \\
\hline $\begin{array}{l}\text { Rel. bank treated } \\
\text { in 1952/57 }\end{array}$ & 0.016 & 0.014 & 0.009 & 0.025 & 0.042 & 0.020 \\
Observations & $(0.018)$ & $(0.017)$ & $(0.017)$ & $(0.017)$ & $(0.026)$ & $(0.035)$ \\
$\mathrm{R}^{2}$ & 372 & 349 & 329 & 311 & 301 & 236 \\
Mean (std. dev.) of outcome & 0.001 & 0.145 & 0.001 & 0.197 & 0.008 & 0.293 \\
Industry FE*zone FE & -0.006 & $(0.201)$ & -0.013 & $(0.159)$ & -0.080 & $(0.225)$ \\
ln age*zone FE & No & Yes & No & Yes & No & Yes \\
Size bin FE*zone FE & No & Yes & No & Yes & No & Yes \\
Excludes 1952-56 & No & Yes & No & Yes & No & Yes \\
\hline
\end{tabular}

Notes: The table estimates the effect of having a relationship bank treated in 1952 on changes in the volatility of firm employment growth. The outcome is the difference in the standard deviation of firm employment or sales growth for the years after the 1952 reform versus before the 1952 reform. Columns 1 and 2 analyze the standard deviation of employment growth using all years with available employment data, while columns 3 and 4 exclude the years from 1952 to 1956, i.e., the years between the first and the second reform. Columns 5 and 6 analyze the standard deviation of revenue growth using all years with available sales data. The regressors and controls are explained in Table I. The data are from an unbalanced firm panel from 1946 to 1970. Standard errors are clustered at the level of the firm's county. 
Table A.XXI: Effects on the volatility of municipality growth

\begin{tabular}{lcc}
\hline & $(1)$ & $(2)$ \\
\hline Outcome & $\begin{array}{c}\text { Conditional absolute deviation in growth of } \\
\text { municipal employment }\end{array}$ \\
\hline Bank branches joint in $1952 *$ post 1952 & 0.005 & -0.002 \\
& $(0.003)$ & $(0.009)$ \\
Bank branches joint in $1957 *$ post 1957 & -0.006 & -0.005 \\
& $(0.004)$ & $(0.005)$ \\
Observations & 1,665 & 1,665 \\
$\mathrm{R}^{2}$ (within municipality) & 0.348 & 0.357 \\
Mean (std. dev.) of outcome & \multicolumn{2}{c}{$0.027(0.033)$} \\
Municipality FE and time FE & Yes & Yes \\
Zone FE*(post 1952, post 1957) & No & Yes \\
Size bin FE*(post 1952, post 1957) & No & Yes \\
Ruhr FE*(post 1952, post 1957) & No & Yes \\
\hline
\end{tabular}

Notes: To calculate the outcome, I use a first stage regression of the annual symmetric employment growth rate on municipality and time fixed effects. The absolute value of the residual from the first stage regression is the outcome variable in the specifications reported in the table. Intuitively, it measures the absolute deviation of a given municipality's growth relative to the average growth of all municipalities in that time and relative to the given municipality's average growth over all time periods. I regress the fluctuation measure on indicators for the periods after the 1952 reform (post 1952) and after the 1957 reform (post 1957), interacted with indicators for whether the municipality had a bank branch treated in the given time. The remaining regressors and controls are explained in Table V. The data are from an unbalanced panel of municipalities with two observations per year from 1948 to 1961. Standard errors are clustered at the level of the municipality. 
Table A.XXII: Effects on the synchronization of firm growth

\begin{tabular}{|c|c|c|c|c|}
\hline \multirow{3}{*}{$\begin{array}{l}\text { Outcome } \\
\text { Rel. banks consolidated in } 1952 * \text { post } 1952\end{array}$} & \multirow{2}{*}{\multicolumn{2}{|c|}{$\begin{array}{c}\text { Absolute difference betwee } \\
\text { Employment }\end{array}$}} & \multicolumn{2}{|l|}{ (3) } \\
\hline & & & ms in condi & 1 growth of \\
\hline & $\begin{array}{c}-0.001 \\
(0.006)\end{array}$ & $\begin{array}{c}-0.003 \\
(0.005)\end{array}$ & $\begin{array}{c}-0.007 \\
(0.011)\end{array}$ & $\begin{array}{c}-0.003 \\
(0.010)\end{array}$ \\
\hline Rel. banks consolidated in $1957 *$ post 1957 & $\begin{array}{c}-0.000 \\
(0.003)\end{array}$ & $\begin{array}{c}-0.000 \\
(0.004)\end{array}$ & $\begin{array}{c}-0.008 \\
(0.007)\end{array}$ & $\begin{array}{l}-0.012 \\
(0.007)\end{array}$ \\
\hline Observations & $5,276,448$ & $3,086,033$ & $1,250,952$ & 556,437 \\
\hline $\mathrm{R}^{2}$ (within firm pair) & 0.014 & 0.019 & 0.009 & 0.014 \\
\hline Mean (std. dev.) of outcome & 0.11 & 143) & 0.15 & 166) \\
\hline Firm pair FE and year FE & Yes & Yes & Yes & Yes \\
\hline Same zone FE*(post 1952 , post 1957 ) & No & Yes & No & Yes \\
\hline Same industry FE*(post 1952 , post 1957 ) & No & Yes & No & Yes \\
\hline Same age $\mathrm{FE}^{*}($ post 1952 , post 1957$)$ & No & Yes & No & Yes \\
\hline Same size bin $\mathrm{FE}^{*}$ (post 1952 , post 1957 ) & No & Yes & No & Yes \\
\hline
\end{tabular}

Notes: Each observation in the dataset is for a pair of firms $a$ and $b$. The outcome is the absolute difference in conditional growth between $a$ and $b$, where conditional growth is the residual from a first stage regression of a firm's annual symmetric growth rate on firm and time fixed effects. Intuitively, the outcome measures the absolute difference in growth between two firms, accounting for permanent differences in growth rates across firms and for common differences in growth rates across years. The reported regressors are indicators for whether the firms had relationship banks in 1951 that were not part of the same bank before the given year, but consolidated because of the banking reform in the given year, interacted with indicators for the periods after the 1952 reform and 1957 reform, respectively. All specifications include fixed effects for each pair of firms and fixed effects for each year. The additional controls are indicators for whether the municipalities in the pair were in the same zone, the same industry, of the same age, and in the same size bin, interacted with indicators for the periods after the 1952 and 1957 reforms. The data are from an unbalanced firm panel from 1946 to 1970. Standard errors are two-way clustered at the level of the counties of the two firms. 
Table A.XXIII: Effects on the synchronization of municipality growth

\begin{tabular}{lcc}
\hline & $(1)$ & $(2)$ \\
\hline Outcome & $\begin{array}{r}\text { Absolute difference between municipalities in } \\
\text { conditional growth of employment }\end{array}$ \\
\hline Branches consolidated in $1952 *$ post 1952 & -0.0005 & -0.0003 \\
& $(0.0020)$ & $(0.0022)$ \\
Branches consolidated in 1957* post 1957 & -0.0001 & -0.0002 \\
& $(0.0012)$ & $(0.0017)$ \\
Observations & 52,534 & 52,534 \\
$\mathrm{R}^{2}$ (within municipality pair) & 0.107 & 0.108 \\
Mean (std. dev.) of outcome & & $0.033(0.042)$ \\
Municipality pair FE and time FE & Yes & Yes \\
Same zone FE*(post 1952, post 1957) & No & Yes \\
Same size bin FE*(post 1952, post 1957) & No & Yes \\
Both in Ruhr FE*(post 1952, post 1957) & No & Yes \\
\hline
\end{tabular}

Notes: Each observation in the dataset is for a pair of municipalities, $i$ and $j$. The outcome is the absolute difference in the conditional growth of employment between $i$ and $j$, where conditional growth is the residual from a first stage regression of a municipality's symmetric employment growth rate on municipality and time fixed effects. Intuitively, the outcome measures the absolute difference in growth between two municipalities, accounting for permanent differences in growth rates across municipalities and for common differences in growth rates across time. The reported regressors are indicators for whether the municipalities had branches of banks that were not part of the same bank before the given year, but became part of the same bank because of the banking reform in the given year, interacted with indicators for the periods after the 1952 reform and 1957 reform, respectively. All specifications include fixed effects for each pair of municipalities and fixed effects for each year. The additional controls are indicators for whether the municipalities in the pair were in the same zone, in the same size bin, and both in the Ruhr region, interacted with indicators for the periods after the 1952 and 1957 reforms. The data are from an unbalanced panel with two observations per year from 1948 to 1961. Standard errors are two-way clustered at the level of the two municipalities. 


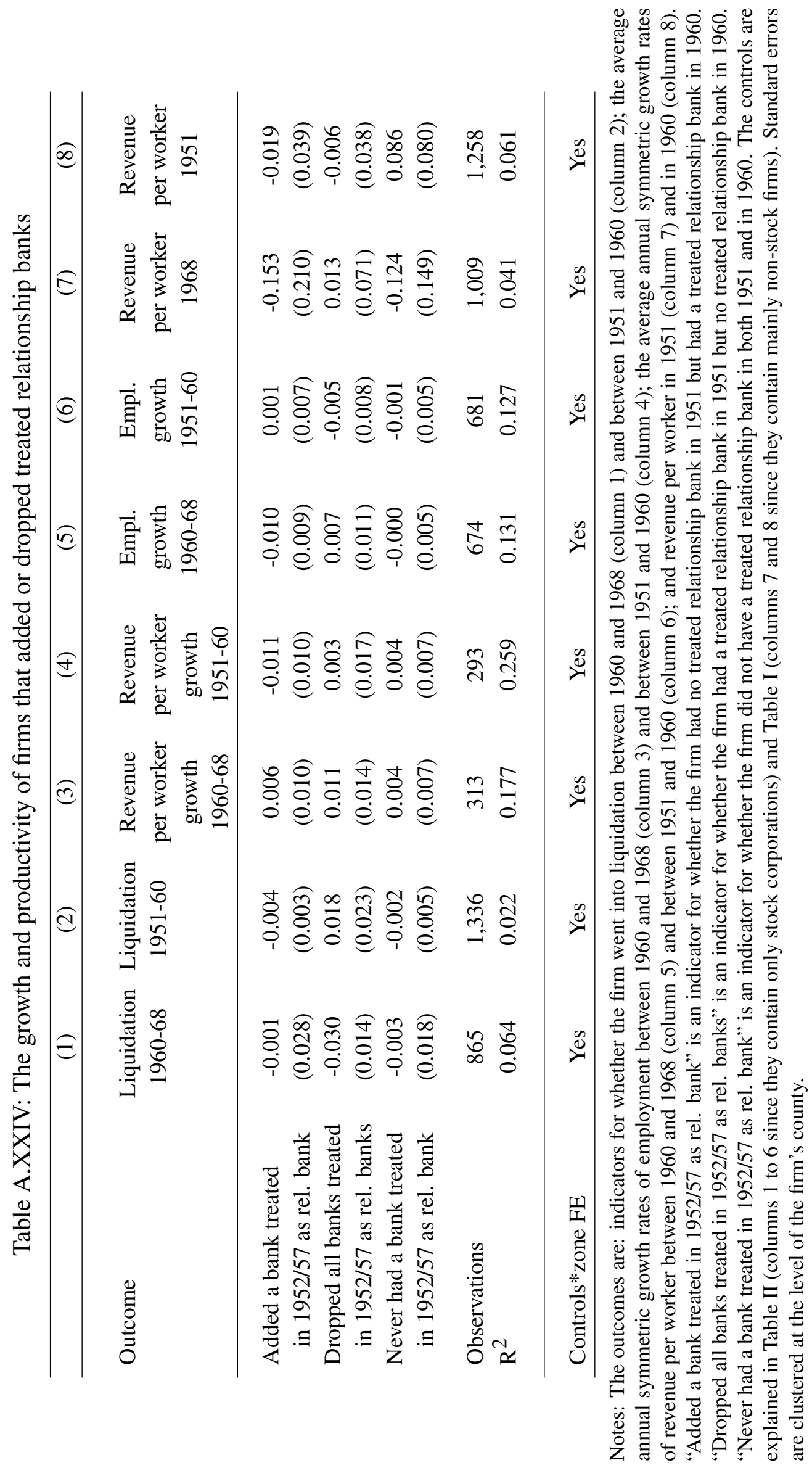




\section{Appendix B Theoretical Model}

I present a simple model of a firm borrowing from a relationship bank. The model illustrates how size-induced changes to bank efficiency can affect firms. The model also highlights the empirical challenge in identifying the causal effects of bank size.

Firms I assume that a firm can only borrow from one relationship bank. The motivation for this assumption is that German firms rely on one or a few relationship banks for financial services. This implies that a relationship bank holds a "bilateral monopoly" over each relationship borrower (Boot 2000). Firm $i b$ maximizes profits $\pi_{i b}$ :

$$
\pi_{i b}=A_{i b} K_{i b}^{\alpha}-r_{i b} K_{i b}
$$

Capital $K_{i b}$ is the sole input, which the firm borrows at an interest rate $r_{i b}$ from its relationship bank. The firm takes the interest rate as given. $A_{i b}$ captures all exogenous factors shifting the firm's demand for capital, such as productivity or demand for the firm's products. The returns-to-scale production parameter is $\alpha$, where $\alpha$ is time-invariant and $0<\alpha<1$. The firm's optimal demand for capital is given by:

$$
\alpha A_{i b} K_{i b}^{(\alpha-1)}=r_{i b}
$$

Banks Bank $b$ lends to a total of $n_{b}$ relationship borrowers. The bank takes the total number of borrowers as given. It earns interest income, which is the interest rate charged to each borrower, $r_{i b}$, multiplied by the amount of capital lent to that firm, $K_{i b}$, summed over all firms. The bank also takes as given the capital demand of each relationship borrower (equation A1).

Banks pay a constant marginal cost for each unit of lent capital, $c\left(n_{b}, \beta_{b}\right)$. This marginal cost includes expenditures on risk management, employees, and deposits. The marginal cost is a function of bank efficiency parameter $\beta_{b}$ and the total number of borrowers $n_{b}$. The marginal cost is decreasing in bank efficiency $\beta_{b}$. An increase in the number of borrowers $n_{b}$ can affect bank operations through multiple channels, as outlined in Section VII. The net effect of bank size on bank costs is theoretically ambiguous. Each bank maximizes profits $\pi_{b}$ :

$$
\pi_{b}=\sum_{i=1}^{n_{b}}\left[r_{i b} K_{i b}-c\left(n_{b}, \beta_{b}\right) K_{i b}\right]
$$

where the first term in the bracket is the interest income from lending to firm $i b$ and the second term in the bracket is the total cost of lending to firm $i b$.

Equilibrium Combining equations A1 and A2 and taking the first-order condition gives the optimal amount of $K_{i b}$. This amount increases with the exogenous capital demand shock $A_{i b}$ and 
decreases with the marginal cost of lending $c\left(n_{b}, \beta_{b}\right)$ :

$$
\ln \left(k_{i b}\right)=\frac{1}{1-\alpha}\left[\ln \left(A_{i b}\right)-\ln \left(c\left(n_{b}^{\prime}, \beta_{b}^{\prime}\right)+\ln \left(\alpha^{2}\right)\right]\right.
$$

For concreteness, I assume a simple parametric specification for the marginal cost of lent capital:

$$
\ln \left(c\left(n_{b}, \beta_{b}\right)\right)=-\phi n_{b}-\kappa \beta_{b},
$$

where $\phi$ is either positive or negative (since the effect of size on marginal cost is ambiguous) and $\kappa$ is strictly positive (since the effect of efficiency on cost is strictly positive). Under this assumption, the change in capital lent to firm $i b$ from period $t$ to period $t^{\prime}$ is given by:

$$
\Delta^{t, t^{\prime}}\left[\ln \left(K_{i b}\right)\right]=\frac{1}{1-\alpha} \times \Delta^{t, t^{\prime}}\left[\ln \left(A_{i b}\right)\right]+\frac{\phi}{1-\alpha} \times \Delta^{t, t^{\prime}}\left[n_{b}\right]+\frac{\kappa}{1-\alpha} \times \Delta^{t, t^{\prime}}\left[\beta_{b}\right] .
$$

The operator $\Delta^{t, t^{\prime}}[$.$] indicates the growth of the variable in square brackets from t$ to $t^{\prime}$. Changes in firm capital demand $A_{i b}$, the number of the bank's relationship borrowers $n_{b}$ (i.e., bank size), and bank efficiency $\beta_{b}$ determine the growth in capital lent. The coefficient $\frac{\phi}{1-\alpha}$ measures the causal effect of changes in bank size on firm growth, the key object of interest in this paper.

Empirical Challenge The empirical challenge in estimating the causal effect of bank size is that changes in firm capital demand $A_{i b}$ and bank efficiency $\beta_{b}$ are typically unobservable in the data. This means that the regression specification one can actually estimate is:

$$
\Delta^{t, t^{\prime}}\left[\ln \left(K_{i b}\right)\right]=\frac{\phi}{1-\alpha} \times \Delta^{t, t^{\prime}}\left[n_{b}\right]+v_{i b}
$$

Firm capital demand and bank efficiency enter the unobservable error term $v_{i b}$ :

$$
v_{i b}=\frac{1}{1-\alpha} \times \Delta^{t, t^{\prime}}\left[\ln \left(A_{i b}\right)\right]+\frac{\kappa}{1-\alpha} \times \Delta^{t, t^{\prime}}\left[\beta_{b}\right]
$$

A regression based on equation A3 estimates the true causal coefficient $\frac{\phi}{1-\alpha}$ if changes in firm capital demand and bank efficiency are uncorrelated with changes in bank size. However, banks do not become big randomly. For example, banks might strategically consolidate with other banks because they expect increases in the future efficiency of the other banks that are unrelated to size. Alternatively, a random shock to regional productivity can simultaneously increase the growth of incumbent bank borrowers and raise the size of banks operating in that region via higher firm entry. In both these examples, the observed correlation between bank size and firm growth would be positive, even if the true causal coefficient $\frac{\phi}{1-\alpha}$ is zero. Therefore, correlations between bank size and firm growth are not informative about how changes in bank size causally affect firm growth. A suitable empirical approach needs to identify a change in bank size that did not simultaneously affect firm capital 
demand, bank efficiency, and other unobservable components of firm and bank performance.

I estimate the effect of the reforms by adapting equation A3. I replace the regressor with an indicator for whether one of the firm's relationship banks increased in size due to a postwar reform between the years $t$ and $t^{\prime}$. This regressor serves as proxy for an increase in the number of the bank's borrowers, i.e., the term $\Delta^{t, t^{\prime}}\left[n_{b}\right]$ from equation A3. ${ }^{\mathrm{A} 1}$ The outcome is still the growth of firm $i b$ from period $t$ to period $t^{\prime}$ :

$$
\Delta^{t, t^{\prime}}\left[\ln \left(K_{i b}\right)\right]=\theta \cdot\left(\text { relationship bank treated between } t \text { and } t^{\prime}\right)_{b}+\eta \cdot X_{i b}+\varepsilon_{i b}
$$

Since the error term is uncorrelated with the treatment indicator, $\theta$ measures the causal impact of having a treated relationship bank.

\section{Appendix C Firm Data Construction and Summary Statistics}

The main dataset builds on the 1952 and 1958/59 Grossunternehmen and the 1952/53 and 1961/62 Aktiengesellschaften volumes. Figure A.III displays a photograph of a page in the 1952/53 volume on Aktiengesellschaften. From these volumes, I digitize the records of all non-financial firms that, at a minimum, contain the names of the firm's relationship banks. There are 2,882 such stock corporations and 4,589 such non-stock firms in the 1952/53 volumes.

Using the firm name and address as identifiers, I perform a fuzzy match procedure (Stata command "reclink") to connect firm entries from the 1952/53 volumes to the 1958/59 and 1961/62 volumes. I check all matches by hand to ensure there are no errors. Firm exits, mergers, and liquidation proceedings are reported in individual firm records and in lists at the end of the Hoppenstedt volumes. To account for the mergers, I aggregate the employment and balance sheet values of all firms participating in the merger, record all their relationship banks, and keep only the aggregated observation in the dataset for the years before the merger. Overall, the match leaves 2,188 stock corporations and 3,706 non-stock firms in the dataset.

A Hoppenstedt volume reports data for one to three years prior to the release year of the volume. For instance, the 1952 volume mostly reports data for 1951, while the 1958/59 volume mostly covers 1956. For the firms in Aktiengesellschaften, I can calculate the growth of employment, revenue per worker, total assets, liabilities, and bank debt from 1951 to 1960. For the firms in Grossunternehmen, it is possible to calculate employment growth from 1951 to 1956 . Some firm entries in the 1952/53 volumes report employment in 1949, so I can calculate the pre-reform growth of these firms from 1949 to 1951.

To supplement the main analyses, I collect additional data on relationship banks, employment, and revenue from the 1941 and 1970 Grossunternehmen and the 1970/71 Aktiengesellschaften vol-

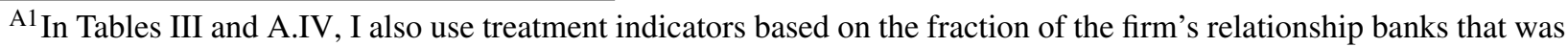
treated.
} 
umes. No data on relationship banks exist in the Aktiengesellschaften volumes prior to 1952. I match 373 firms between the 1941 and 1952/53 volumes and 4,191 firms between the 1952/53 volumes and 1970/71 volumes.

The median stock corporation in the sample was of a similar size and age to the median nonstock firm (Table A.I). Both had close to 350 employees in 1951. The very largest firms were stock corporations, which means that the average stock corporation was larger than the average non-stock firm. Both stock capital and bank debt were important sources of stock corporations' financing, amounting to an average of 37 percent and 10 percent of total assets, respectively.

In the sample, 14 percent of stock corporations and 6 percent of non-stock firms have fewer than 50 employees. As a rough comparison, the fraction of establishments in the population with fewer than 50 employees was 98 percent in 1951 (Statistisches Bundesamt 1952). 70 percent of firms in the sample are in the manufacturing sector, compared to 32 percent of establishments in the population. All specifications in the results section control for firm size and industry, to ensure differences in size and industry do not drive the findings. I also explore heterogeneity related to size and industry.

\section{Appendix D Robustness Checks for the Analysis of Firm Growth}

The effect of having a treated relationship bank is similar when I exclude firms that might have participated in war-related production during World War II (column 1, Table A.IV). War-related firms might have grown more slowly in the postwar period, because they had to restructure their business model or because of Allied punishment. I exclude firms listed in Anlage Nr. 6 and 10 in Hansen (1978), which contributed to armaments production in the 1930s. I also exclude all warrelated industries: mining, clothes \& textiles, chemicals \& pharmaceuticals, metals manufacturing, electric \& electronics, and production of machinery.

The coefficients are stable when analyzing firms that had more than half of their relationship banks treated (column 2). All the firm-level results are similar across the three treated banking groups. This suggests that the results are not specific to one individual institution, but instead driven by more general mechanisms (column 3). Finally, I find similar results when I use relationship banks from 1940 to define the treatment indicators (Table A.XIV). This is not surprising, given that 87 percent of firms with a treated relationship bank in 1940 still had a treated relationship bank in 1951.

\section{Appendix E Municipality Data}

The municipality data are hand-digitized from the publication Statistisches Jahrbuch deutscher Gemeinden. I digitize employment data for 1951, 1956, and 1960, matching the years for which I have firm employment data. The annual bank reports identify whether a municipality had a treated bank branch. Sectoral employment shares are from the 1950 Betriebszählung (census of enterprises). 
Average employment in the municipalities in the sample was 64,992 in 1951. 86 percent of municipalities had a bank branch treated in either 1952 or 1957. 52 percent had a bank branch treated in the 1952 reform.

\section{Appendix F Competitive Changes in Local Banking Markets}

The competitive environment in local banking markets might have changed after the consolidations. For example, if the treated banks became more efficient after 1952, untreated banks might have been forced to raise their efficiency as well. This would imply that there was no difference between firms with a treated relationship bank and other firms in the same local banking market, even though all banks' efficiency improved after the consolidations.

To investigate this possibility, I test whether the effect of having a treated relationship bank differed in municipalities where treated branches only formed a small part of the market. The impact of the consolidations on competitive pressures was likely weaker in such municipalities. I find no evidence that treated firms grew more quickly than untreated firms in municipalities with low exposure to the treated banks (Table A.XV). This suggests that even in municipalities where competitive pressures were relatively weak there was no benefit to having a treated relationship bank.

\section{Appendix G Robustness Checks for the Analysis of Municipality Growth}

I regress municipality characteristics on a constant and an indicator for whether the municipality had a treated bank branch. I analyze all municipality characteristics that are reported in my municipal data sources Statistisches Jahrbuch deutscher Gemeinden and the 1950 Betriebszählung (census of enterprises). I find that municipalities with a treated branch were similar in terms of sectoral shares and location to other municipalities (Table A.XVI).

Next, I explore whether differences in municipality size can explain the results. There is a mechanical relationship between municipality size and having a treated bank branch: the larger a municipality, the greater the total number of bank branches, the more likely that a treated bank has a branch in the municipality. I confirm the relationship between municipality size and having a treated branch by regressing log total employment on the indicator for a treated branch. The coefficient is positive and statistically significant (column 1, Table A.XVII).

I investigate whether the municipality-level results are driven by this relationship using several strategies. I first restrict the sample to municipalities where total employment was at most as large as total employment in the largest untreated municipality. The idea is to only use municipalities where we know that size did not mechanically guarantee that there would be a treated branch. In this sample, the association between size and having a treated branch is small and insignificant (column 3 ), while the effect of having a treated branch remains close to the baseline and significant (column 4). Next, I restrict the sample to municipalities with below-median total employment. In this sample, 
the relationship between size and having a treated branch is also small and insignificant (column 5). The estimated effect of having a treated branch on employment growth remains close to the baseline although the small sample renders the coefficient insignificant (column 6).

The baseline estimate (column 2) controls for fixed effects for five quantiles of total employment. To test the robustness of the result, I instead control for log size (column 7), fixed effects for terciles of size (column 8), and fixed effects for deciles (column 9). The point estimates in all these specifications remain close to the baseline estimate and statistically significant. In summary, the effect of having a treated bank branch survives in samples where there is no association between municipality size and having a treated branch. Furthermore, the results are not sensitive to how I control for size. This implies that the effect of having a treated branch cannot be explained by the fact that larger municipalities are more likely to have a treated branch.

\section{Appendix H Estimation of Cost and Profit Efficiency Ratios}

I follow the procedures outlined in Sections 2.1 (cost efficiency) and 2.3 (alternative profit efficiency) of Berger and Mester 1997 to construct the efficiency measures. Cost efficiency is estimated by specifying a cost function where variable costs depend on prices of variable inputs, quantities of variable outputs, quantities of fixed inputs and outputs, other potential determinants of bank performance, and an error term composed of a random term and bank-specific inefficiency. The cost efficiency ratio of a given bank is an estimate of the costs needed to produce the bank's output if the bank were as efficient as the best-practice bank, divided by the predicted costs of the given bank, net of random error. The higher the ratio, the closer a given bank's efficiency is to the best-practice bank in the sample.

Alternative profit efficiency is estimated using a similar specification as the cost function, but with variable profits (plus minimum profits in the sample plus 1) as dependent variable. The profit efficiency ratio of a given bank is an estimate of the predicted profits of the bank divided by predicted profits of the bank if the bank were as efficient as the best-practice bank in the sample, net of random error. I report alternative profit efficiency instead of standard profit efficiency because alternative efficiency allows for the possibility that banks have market power and for unmeasured quality differences in bank outputs (Berger and Mester 1997).

The baseline results in columns 4 to 7 of Table VI are from a translog specification. The estimation method follows the stochastic frontier approach and assumes that the random error is normally distributed and that the inefficiency term is half-normally distributed, as in a study of European banks by Vander Vennet (2002). The baseline regressors are input prices (prices of deposits and labor), outputs (loans and securities), and fixed inputs and outputs (financial capital and physical capital). In

robustness checks, I alternatively assumed a truncated normal and exponential distributions for the inefficiency term; I included the unemployment rate of the state in which the bank operated and its square among the regressors, to account for heterogeneity in the banks' economic environments; and 
I added Fourier trigonometric terms to the specification. The results of these robustness checks are similar to the ones reported in Table VI.

\section{Appendix I Volatility of Banking Groups' Financial Figures}

If the treated banks became less exposed to idiosyncratic shocks after consolidating, their aggregated financial figures should have become less volatile compared to untreated banks. For example, imagine that a given number of borrowers default every year for idiosyncratic reasons. If the treated banks became less exposed to these defaults, they would have experienced proportionally smaller hits to their capital stock and lending capabilities after consolidating. This, in turn, would have allowed them to limit the subsequent reductions in new lending and total assets. In addition, depositors would have been less concerned about bank failure and less likely to withdraw their funds. (German deposit insurance only started in 1976, so this applies to both bank and non-bank depositors.)

I use data from the Deutsche Bundesbank to analyze the volatility of the treated banks. The data are aggregated at the level of seven different banking groups. One group are the treated banks. Other groups include untreated commercial banks, private banks, savings banks, cross-regional cooperative banks, regional cooperative banks, and mortgage banks. The data include two observations per year from 1948 to $1970 .^{\text {A2 }}$

To analyze bank volatility, I adopt the procedure introduced by Morgan et al. (2004). In particular, I regress the log change in a given financial variable $C_{g t}$ (growth in assets, lending, or deposits for banking group $g$ at time $t$ ) on a full set of fixed effects for banking groups $\left(\alpha_{g}\right)$ and for time $\left(\alpha_{t}\right)$ :

$$
C_{g t}=\alpha_{g}+\alpha_{t}+\varepsilon_{g t}
$$

The absolute value of the residual $\left(\left|\varepsilon_{g t}\right|\right)$ is a measure of the fluctuation in growth for a given banking group in a given year. Intuitively, it is the absolute deviation of a banking group's growth relative to the average growth of all banking groups in that year and relative to the given banking group's average growth over all years. I regress the fluctuation measure on indicators for the years after 1952 (post52 ${ }_{t}$ ) and after 1957 (post $57_{t}$ ), interacted with an indicator for the treated banking group (treated $_{g}$ ). I control for time fixed effects and banking group fixed effects. The latter absorb all time-invariant differences across the banking groups:

$$
\left|\varepsilon_{g t}\right|=\beta_{1} \cdot \text { treated }_{g} \cdot \text { post } 52_{t}+\beta_{2} \cdot \text { treated }_{g} \cdot \text { post } 57_{t}+\mu_{g}+\mu_{t}+v_{g t} \text {. }
$$

The results are in columns 1 to 3 of Table A.XVIII. The three post-1952 coefficients are positive and statistically insignificant. This means, if anything, the fluctuations for the treated banking group marginally increased after 1952, relative to other banking groups. All three post-1957 coefficients

\footnotetext{
${ }^{A 2}$ The annual reports of many treated and untreated banks from the 1940s and 1950s have not been preserved, so I rely on the Bundesbank data on banking groups instead. The data do not report items from the income statement.
} 
are smaller in absolute terms than the post-1952 coefficients. This implies that after 1957, fluctuations of the treated banks still remained larger than before 1952, relative to other banking groups.

Diversification might have been particularly effective during recessions. In columns 4 to 6 , I test whether fluctuations differed during the 1966/67 recession, by adding an indicator for treated banking groups during the recession. The coefficients are positive, small, and insignificant. This suggests that fluctuations of treated banks were not lower during the recession.

I carry out several robustness checks: I use squared residuals $\left(\varepsilon_{g t}^{2}\right)$ for the outcome; I exclude from the sample all government-owned and cooperative banking groups to make the banking groups

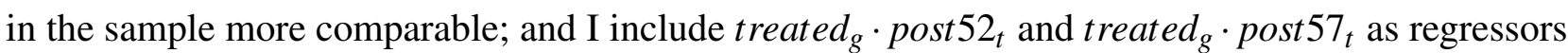
in equation A4 to control for level effects on the growth rate. In all specifications, there is no evidence that volatility of assets, lending, or deposits fell by more for the treated banks.

\section{Appendix J Volatility and Synchronization of Growth}

Volatility of Growth: Potential Mechanisms How could the postwar bank consolidations affect the volatility of borrower growth? The answer depends on whether the consolidations affected capital flows and on whether shocks to bank lending capabilities or shocks to loan demand predominated in postwar Germany (Morgan et al. 2004).

First, consider an exogenous reduction in the lending capabilities of branches of one treated bank in one state. Before 1952, the branches formed a separate bank. They could stabilize their loan supply by borrowing funds from other banks through interbank markets. After 1957, the branches were part of a national bank. They had the additional option of receiving funds from out-of-state branches through an internal capital market. If the availability of internal funds after 1957 stabilized loan supply, exogenous shocks to lending capabilities would have affected borrowers by less. But if interbank funds after 1957 were as readily available as internal funds before 1952, volatility would have remained unchanged after 1957.

Second, consider an exogenous drop in loan demand in one state. Before 1952, treated branches in that state could respond by reducing loan supply to in-state borrowers and lending more to other banks through interbank markets. After 1957, treated branches had the additional option of sending funds to out-of-state branches through their internal capital market. If the flow of internal funds after 1957 was larger than the flow of interbank funds before 1952, exogenous shocks to loan demand would have led to greater volatility in the supply of funds in the state and, ultimately, greater volatility of borrower growth. But if internal flows were as large as interbank flows, there would have been no change in volatility after 1957.

Volatility of Firm Growth: Method 1 I use two methods to measure firm volatility. The first follows Morgan et al. (2004). In a first stage, I regress the change in annual firm growth (in employment 
or revenue) for firm $f$ in year $t$ on fixed effects for firms $\left(\theta_{g}\right)$ and years $\left(\theta_{t}\right)$ :

$$
\text { Growth }_{f t}=\theta_{f}+\theta_{t}+\varepsilon_{f t} .
$$

The absolute value of the residual $\left(\left|\varepsilon_{f t}\right|\right)$ measures the fluctuation in growth relative to the average growth of all firms in year $t$ and relative to the average growth of firm $f$ in all years. I regress $\left|\varepsilon_{f t}\right|$ on indicators for having a relationship bank treated in 1952 and 1957 (rel bank treated in $1952_{f}$ and rel bank treated in $1957_{f}$ ), interacted with indicators for the years after 1952 (post52 $2_{t}$ ) and after 1957 (post57 $t$ ), respectively. I control for firm and year fixed effects:

$\left|\varepsilon_{f t}\right|=\beta_{1} \cdot$ rel bank treated in $1952_{f} \cdot$ post $52_{t}+\beta_{2} \cdot$ rel bank treated in $1957_{f} \cdot$ post $57_{t}+\lambda_{f}+\lambda_{t}+\xi_{f t}$.

The estimates of $\beta_{1}$ and $\beta_{2}$ are small and statistically insignificant, using either employment fluctuations (column 1, Table A.XIX) or revenue fluctuations (column 3) as outcome. Adding the controls, interacted with post $52_{t}$ and post $57_{t}$, makes little difference to the estimates (columns 2 and 4 ). The results imply that firm volatility did not change significantly after a relationship bank consolidated. The results are similar when using the squared residual to construct the outcome $\left(\varepsilon_{f t}^{2}\right)$ and when including rel bank treated in $1952_{f} \cdot$ post $52_{t}$ and rel bank treated in $1957_{f} \cdot$ post $57_{t}$ as regressors in first stage equation A5 to control for potential level effects (which turn out to be small and insignificant).

Volatility of Firm Growth: Method 2 The second method analyzes the standard deviation of annual employment and annual revenue growth. I measure the change in volatility as the difference in the standard deviation of growth after versus before the 1952 reform. In Table A.XX, I regress the change in volatility on an indicator for whether a firm had a relationship bank treated in 1952 or 1957. The point estimates are statistically insignificant and relatively small, without controls (column 1) and with controls (column 2). The results are similar when I exclude the years 1952 to 1956 from the calculation of the standard deviation, to ensure that the period between the two reforms does not drive the results (columns 3 and 4). I find similar results for the standard deviation of revenue growth (columns 5 and 6).

Volatility of Municipality Growth I also analyze the volatility of municipal employment growth. I use data from the publication series Statistisches Jahrbuch deutscher Gemeinden for the years from 1947 to 1961, two observations per year. I use a similar method as for the firm-level analysis (based on Morgan et al. 2004). The outcome is the absolute deviation of municipality growth from average growth of the municipality over all years and average growth of all municipalities in the year. The estimates are small, of varying signs, and unaffected by adding the controls (Table A.XXI). The results are robust to using squared residuals as outcome and including the treatment indicators in the first stage regression. 
Summary of Results on Volatility Taken together, the evidence from firms and municipalities indicates that the volatility of growth was not affected. The findings are consistent with the earlier results, which suggested that internal capital markets did not significantly alter capital flows across states and the level of firm and municipality growth.

Synchronization of Growth: Potential Mechanisms The banking consolidations could have affected the synchronization of real growth across firms and municipalities. The potential mechanisms are similar to the ones driving volatility (Morgan et al. 2004). If cross-state capital flows changed significantly, synchronization should have increased after loan supply shocks and decreased after loan demand shocks. Since the earlier evidence suggested that volatility did not change, I also expect no change in synchronization.

Synchronization of Firm Growth: Specification The outcome is the absolute value of the difference between the residuals from the first stage equation A5. That means, for a pair consisting of firms $a$ and $b$, the outcome is $\left|\varepsilon_{a t}-\varepsilon_{b t}\right|$. For every pair of firms in the data, I construct two variables that indicate whether the relationship banks of the two firms consolidated as a result of the 1952 and 1957 reforms, respectively. The regressors of interest are these two variables, interacted with indicators for the periods after the 1952 and 1957 reforms, respectively. All specifications include fixed effects for each firm pair, to account for pre-existing differences across pairs, and fixed effects for each year.

Synchronization of Firm Growth: Results I find no evidence that the consolidation of two firms' relationship banks had any effect on the synchronization of firms' growth, using either employment (column 1, Table A.XXII) or revenue (column 3) to define the outcome. The results are robust to controlling for whether firms in each pair were in the same zone, the same industry, of the same age, or in the same size bin (columns 2 and 4). By including the controls, I ensure that common shocks to firms in a certain zone, industry, age, or size bin do not bias the result.

Synchronization of Municipality Growth: Specification I follow an analogous method to analyze the synchronization of municipality growth, using a dataset of municipality pairs. The regressors of interest indicate whether the municipalities had bank branches that became part of the same bank as a result of a reform, interacted with an indicator for the period after the given reform. The outcome is the absolute difference in conditional employment growth between the two municipalities, where conditional growth is the residual from a regression of growth on year and municipality fixed effects.

Synchronization of Municipality Growth: Results The coefficients of interest are all small and statistically insignificant (column 1, Table A.XXIII). Adding controls for whether municipalities 
were in the same zone, the same size bin, and both in the Ruhr region hardly changes the coefficients (column 2). Overall, there is no evidence that synchronization changed as a result of the banking reforms.

\section{Appendix K Firm Performance After Being Added as Relationship Borrower by a Treated Bank}

Did the treated banks establish relationships with low-default borrowers? Column 1 of Table A.XXIV uses as outcome an indicator for whether the firm went into liquidation between 1960 and 1968. The regressors are indicators for whether the firm had no treated relationship bank in 1951 but one in 1960 ("added a bank treated...”); a treated relationship bank in 1951 but not in 1960 (“dropped all banks treated...”); and no treated relationship bank in either 1951 or 1960 ("never had a bank treated...”). The omitted category contains firms that had a treated relationship bank in both 1951 and 1960. The categories are mutually exclusive, so the coefficients can be interpreted as the average difference in the propensity to face liquidation between 1960 and 1968 for the different types of firms.

The coefficients on the first and third regressors in column 1 are close to zero and statistically insignificant. Hence, newly added relationship borrowers of treated banks as well as firms that were never relationship borrowers of treated banks were not significantly less likely to avoid liquidation, relative to continuing borrowers of treated banks. The second coefficient is negative and significantly different from zero at the 5 percent level. It implies that firms dropped by the treated banks as relationship borrowers were 3 percentage points less likely to avoid liquidation afterward, relative to continuing borrowers of treated banks. ${ }^{\mathrm{A} 3}$ Overall, column 1 suggests that treated banks did not become better at identifying borrowers with lower likelihood to default.

It could be that the banks added and dropped borrowers between 1951 and 1960 based on the borrowers' default likelihood between 1951 and 1960. To explore this possibility, column 2 uses as outcome an indicator for whether the firm went into liquidation between 1951 and 1960. The coefficients are all insignificant and relatively small. The specification in column 2 potentially suffers from reverse causality bias, unlike column 1, since firms in liquidation are likely to be dropped as relationship borrowers at the same time. This might explain the (insignificant) positive point estimate on firms dropped between 1951 and 1960 in column 2, relative to the (significant) negative estimate in column 1. Most important, however, the results once again confirm that firms added or dropped by treated banks were not significantly less likely to avoid default.

\footnotetext{
${ }^{\mathrm{A} 3}$ The unconditional mean propensity to face liquidation was 3 percent. Interestingly, the point estimate is negative 6 percentage points when restricting the sample to opaque firms, although not significantly different from the baseline effect of 3 percentage points. A larger effect on opaque firms would be consistent with the finding that treated banks became worse at dealing with opaque borrowers after consolidating.
} 
Did the treated banks establish relationships with fast-growing borrowers? Columns 3 and 4 of Table A.XXIV use as outcome the growth of revenue per worker, a measure of labor productivity. Columns 5 and 6 use as outcome the growth of employment. There is no evidence that firms added or dropped by the treated banks had differential growth rates. Taken together, the results in columns 1 to 6 are inconsistent with the view that that treated banks added firms with better performance as relationship borrowers, or dropped firms with worse performance.

Did the treated banks establish relationships with more productive borrowers? It could be that the treated banks reallocated credit from low to high productivity firms by adding or dropping relationship borrowers. In that case, firms added as relationship borrowers by the treated banks should have been more productive than other firms, and firms dropped as relationship borrowers less productive. I use revenue per worker as proxy for labor productivity. The results show that revenue per worker in 1968 (column 7) and in 1951 (column 8) was not different for firms added or dropped by the treated banks. This implies that the treated banks did not improve the average labor productivity of their relationship borrowers by selectively adding or dropping firms.

\section{Appendix L The Elasticity of Firm Growth with Respect to Bank Size}

The elasticity is the percentage change in borrower growth that results from a one percent increase in bank size. The first step in calculating the elasticity is measuring by how much each treated bank grew because of the reforms. I use the size of banks before the 1952 reform as basis for the calculation. Using only the pre-1952 assets instead of actual post-1952 assets ensures that the measure of bank size growth is exogenous to any potential effects of the reforms on bank assets.

The method is best explained using an example: before 1952, assets of Suedwestbank (Deutsche Bank successor located in the southern state of Wuerttemberg-Baden) totaled 301 million Deutsche Mark; the aggregated assets of all Deutsche Bank successors in the southern zone totaled 976 million; and aggregated assets of all Deutsche Bank successors in West Germany totaled 2,308 million. For a firm whose only relationship bank in 1951 was Suedwestbank, I calculate the reform-induced change in the size of the firm's banks from 1951 to 1956 as $(976-301) / 301=224.3$ percent and from 1951 to 1960 as $(2,308-301) / 301=666.8$ percent. For firms with only untreated relationship banks, the measure of reform-induced bank size growth is zero, since the reforms had no impact on the size of untreated banks. For firms with multiple relationship banks, the measure is the average change in bank size over all relationship banks.

To estimate the elasticity, I regress the annual percentage change in firm employment on the percentage change in the size of the firm's relationship banks. The sample and specification for this analysis are based on column 1 of Table I. The only difference between Table I and the result here is that the outcome and treatment variables here are in percentage changes, so that the point estimate can be directly interpreted as the elasticity. The estimated elasticity is -0.0009 (95 percent 
confidence interval: $-0.0024,0.0005)$ using the 1952 reform. ${ }^{\mathrm{A} 4}$

\footnotetext{
${ }^{\mathrm{A} 4}$ I find similar results when using symmetric or log growth rates instead of percentage changes. I also estimated the elasticity based on both reforms of 1952 and 1957, using a sample and specification based on column 1, panel A of Table II. The elasticity of employment with respect to bank size is -0.002 (95 CI: -.007, 0.003) and the elasticity of bank debt is 0.0004 (95 CI: $-0.0007,0.0016)$ using both reforms.
} 
CENTRE FOR ECONOMIC PERFORMANCE

Recent Discussion Papers

\begin{tabular}{|c|c|c|}
\hline 1734 & $\begin{array}{l}\text { César Ducruet } \\
\text { Réka Juhász } \\
\text { Dávid Krisztián Nagy } \\
\text { Claudia Steinwender }\end{array}$ & All aboard: the effects of port development \\
\hline 1733 & $\begin{array}{l}\text { Jonathan Colmer } \\
\text { John Voorheis }\end{array}$ & $\begin{array}{l}\text { The grandkids aren't alright: the } \\
\text { intergenerational effects of prenatal pollution } \\
\text { exposure }\end{array}$ \\
\hline 1732 & $\begin{array}{l}\text { Kabir Dasgupta } \\
\text { André Diegmann } \\
\text { Tom Kirchmaier } \\
\text { Alexander Plum }\end{array}$ & $\begin{array}{l}\text { Heterogeneity in criminal behavior after child } \\
\text { birth: the role of ethnicity }\end{array}$ \\
\hline 1731 & $\begin{array}{l}\text { Andreas Diemer } \\
\text { Tanner Regan }\end{array}$ & $\begin{array}{l}\text { No inventor is an island: social connectedness } \\
\text { and the geography of knowledge flows in the } \\
\text { US }\end{array}$ \\
\hline 1730 & $\begin{array}{l}\text { Hanming Fang } \\
\text { Chunmian Ge } \\
\text { Hanwei Huang } \\
\text { Hongbin Li }\end{array}$ & $\begin{array}{l}\text { Pandemics, global supply chains, and local } \\
\text { labor demand: evidence from } 100 \text { million } \\
\text { posted jobs in China }\end{array}$ \\
\hline 1729 & $\begin{array}{l}\text { Ria Ivandić } \\
\text { Tom Kirchmaier } \\
\text { Ben Linton }\end{array}$ & $\begin{array}{l}\text { Changing patterns of domestic abuse during } \\
\text { COVID-19 lockdown }\end{array}$ \\
\hline 1728 & $\begin{array}{l}\text { Jonathan Colmer } \\
\text { Ralf Martin } \\
\text { Mirabelle Muûls } \\
\text { Ulrich J. Wagner }\end{array}$ & $\begin{array}{l}\text { Does pricing carbon mitigate climate change? } \\
\text { Firm-level evidence from the European Union } \\
\text { emissions trading scheme }\end{array}$ \\
\hline 1727 & $\begin{array}{l}\text { Tony Beatton } \\
\text { Michael P. Kidd } \\
\text { Matteo Sandi }\end{array}$ & School indiscipline and crime \\
\hline 1726 & $\begin{array}{l}\text { Maximilian v. Ehrlich } \\
\text { Henry G. Overman }\end{array}$ & $\begin{array}{l}\text { Place-based policies and spatial disparities } \\
\text { across European cities }\end{array}$ \\
\hline
\end{tabular}




\begin{tabular}{|c|c|c|}
\hline 1725 & $\begin{array}{l}\text { Gabriel M. Ahlfeldt } \\
\text { Thilo N. H. Albers } \\
\text { Kristian Behrens }\end{array}$ & Prime Locations \\
\hline 1724 & $\begin{array}{l}\text { Benjamin Handel } \\
\text { Jonathan Kolstad } \\
\text { Thomas Minten } \\
\text { Johannes Spinnewijn }\end{array}$ & $\begin{array}{l}\text { The Social Determinants of Choice Quality: } \\
\text { Evidence from Health Insurance in the } \\
\text { Netherlands }\end{array}$ \\
\hline 1723 & $\begin{array}{l}\text { Claudia Hupkau } \\
\text { Barbara Petrongolo }\end{array}$ & $\begin{array}{l}\text { Work, Care and Gender During the Covid-19 } \\
\text { Crisis }\end{array}$ \\
\hline 1722 & $\begin{array}{l}\text { Ross Levine } \\
\text { Yona Rubinstein }\end{array}$ & $\begin{array}{l}\text { Selection Into Entrepreneurship and Self- } \\
\text { Employment }\end{array}$ \\
\hline 1721 & Sandra McNally & $\begin{array}{l}\text { Gender Differences in Tertiary Education: } \\
\text { What Explains STEM Participation? }\end{array}$ \\
\hline 1720 & $\begin{array}{l}\text { Edoardo di Porto } \\
\text { Paolo Naticchioni } \\
\text { Vincenzo Scrutinio }\end{array}$ & $\begin{array}{l}\text { Partial Lockdown and the Spread of Covid- } \\
\text { 19: Lessons From the Italian Case }\end{array}$ \\
\hline 1719 & $\begin{array}{l}\text { Swati Dhingra } \\
\text { Stephen Machin }\end{array}$ & The Crisis and Job Guarantees in Urban India \\
\hline 1718 & Stephen J. Redding & Trade and Geography \\
\hline 1717 & $\begin{array}{l}\text { Arun Advani } \\
\text { Felix Koenig } \\
\text { Lorenzo Pessina } \\
\text { Andy Summers }\end{array}$ & $\begin{array}{l}\text { Importing Inequality: Immigration and the } \\
\text { Top } 1 \text { Percent }\end{array}$ \\
\hline 1716 & $\begin{array}{l}\text { Pol Antràs } \\
\text { Stephen J. Redding } \\
\text { Esteban Rossi-Hansberg }\end{array}$ & Globalization and Pandemics \\
\hline
\end{tabular}

The Centre for Economic Performance Publications Unit

Tel: +44 (0)2079557673 Email info@cep.lse.ac.uk

Website: http://cep.lse.ac.uk Twitter: @CEP_LSE 